\title{
Composição de interface com etnomusicologia: uma perspectiva materializada em cinco obras contemporâneas
}

Interface Composition with Ethnomusicology: A Perspective Materialized in Five Contemporary Pieces

Vinicius Borges Amaro ${ }^{1}$ Universidade Estadual de Feira de Santana vbamaro@uefs.br 


\section{Resumo}

Este trabalho apresenta discussões acerca do processo composicional de cinco obras compostas a partir de uma perspectiva de interface entre composição e etnomusicologia, centrada numa pesquisa cujo objetivo se estabelece como um estudo da música de candomblé ligado às noções compositivas impressas em seus processos rítmicos. Buscando um suporte em teorias do ritmo (COOPER; MEYER, 1960; KRAMER, 1988; HESTY, 1997), na literatura sobre música de candomblé e música africana (LÜHNING, 1990; KUBIK, 2010; BRANDA LACERDA, 2014; AGAWU, 2016), e por meio de um estudo etnográfico, cinco processos rítmicos foram identificados, conceitualizados e exemplificados: 1) ressignificação rítmica; 2) dissociação rítmica, 3) sintonização rítmica; 4) suspensão rítmica e 5) sublimação rítmica. Estes são problematizados na produção artística em questão, através de um impulso adaptativo relativo ao abrangente imaginário da música de concerto contemporânea, em suas dimensões temporais, texturais, gestuais e formais.

Palavras-chave: Composição; música de concerto contemporânea; candomblé; processos rítmicos; etnomusicologia.

\section{Abstract}

This work presents discussions about the compositional process of five works composed from an interface perspective between composition and ethnomusicology, based on a study of Candomblé music associated to compositional notions from its rhythmic processes. Supported in theories of rhythm (COOPER and MEYER, 1960; KRAMER, 1988; and HESTY, 1997), in the literature on Candomblé music and African music (LÜHNING, 1990; KUBIK, 2010; BRANDA LACERDA, 2014; and AGAWU, 2016), and through an ethnographic approach, five rhythmic processes were identified, conceptualized and exemplified: 1) rhythmic resignification; 2) rhythmic dissociation, 3) rhythmic sintonization; 4) rhythmic suspension; and 5) rhythmic sublimation. These are problematized in the artistic production in question, through an adaptive impulse related to the large imagery of contemporary concert music, in its temporal, textural, gestural and formal dimensions.

Keywords: Composition; Contemporary concert music; Candomblé; Rhythmic processes; Ethnomusicology.

Professor de Composição e Estruturação Musical da Universidade Estadual de Feira de Santana (UEFS). Bacharel, mestre e doutor em composição musical pela Universidade Federal da Bahia (UFBA). Em 2016, com a obra Ritual Ifá, venceu o Concurso para Jovens Compositores, realizado pela OSPA (Orquestra Sinfônica de Porto Alegre), e com a obra Mandinga No 4 (Besouro Mangangá), foi contemplado com o Prêmio Funarte de Composição Clássica. É membro da OCA — Oficina de Composição Agora —, regente e conselheiro artístico do Camará Ensemble. 


\section{Contextualização}

A jornada que se inicia agora visa promover reflexões que tangem as dimensões filosóficas, estéticas e compositivas de cinco obras musicais ligadas ao largo imaginário da música de concerto contemporânea. Como produções artísticas, tais peças respondem a uma pesquisa de interface entre composição e etnomusicologia que estuda a música de candomblé numa perspectiva composicional, objetivando um entendimento de seus processos rítmicos. Esta pesquisa contou com atitudes metodológicas que perpassam a etnografia e a análise musical, todas elas orientadas pelas teorias do ritmo (COOPER; MEYER, 1960; KRAMER; HESTY 1997), da composição (LASKE, 1991; REYNOLDS, 2002), e pela interlocução com o Terreiro do Gantois, ${ }^{2}$ por intermédio do alagbể luri Passos.

Para tanto, é preciso evidenciar que este trabalho existe a partir do reconhecimento da pluralidade epistemológica, o que envolve a percepção da existência de alternativas múltiplas e igualmente valorosas às perspectivas científicas, tecnológicas e artísticas legitimadas pela Europa (SANTOS; MENEZES, 2009), e responde ao movimento em torno duma concepção intercultural, como possibilidade de descolonização do saber e oxigenação do imaginário que o sustenta (QUIJANO, 2005, 2007), no sentido de "assumir o desafio epistemológico do reconhecimento da existência de outras visões de mundo e de aceitar a validade de outros conhecimentos e de outras formas de construir conhecimento" (MARÍN, 2009, p.128).

Nesta direção, até que chegue à seção onde cada uma das obras será abordada em seus valores e características intrínsecas, onde situações composicionais serão devidamente analisadas, discussões que refletem no ideal filosófico e técnico que as fundamentam serão tecidas, dentre elas: 1) a interface "composição e etnomusicologia" e 2) a perspectiva compositiva da música de candomblé, sob a ótica de seus processos rítmicos. Com isto, espera-se contribuir com a área da composição em sua dimensão objetiva de indissociabilidade entre teoria e prática.

\section{Composição e etnomusicologia em interface}

Os anseios e interesses da composição e da etnomusicologia podem estar, ininterruptamente, em estado de complementação. No âmbito desta discussão, um ponto inicial a ser comentado é que, tal como os etnomusicólogos, compositores também se preocupam com relações de poder, ética, política e pensam sobre cultura. Aliás, a crítica e a sua maturação, como uma espécie de ruminação de todas essas instâncias, podem ser tomadas como um fundamento do compor, na medida em que se comporta como a "alavanca que permite aquele distanciamento necessário para que a criatividade se expanda" (WIDMER, 1981, p.1). Obviamente, isto refere-se a uma crítica que, no trabalho composicional, transcende a expressão musical, tomando-a apenas como um veículo 
condutor, superando qualquer resquício conceitual ligado à noção de "música absoluta" (CHUA, 2003).

Para não carecer de exemplos, lembremo-nos do compositor Béla Bartók e de toda a sua importância na formalização da própria etnomusicologia. ${ }^{4}$ Para além do seu empenho no registro de canções ciganas de tradição oral da Romênia, Bulgária, Turquia, dentre outros países, ficaram obras como os seus seis quartetos de cordas e a Cantata Profana, cujos discursos artísticos, influenciados pelos princípios identificados nos materiais registrados, oxigenam os paradigmas ocidentais do compor da música de concerto, incitam discussões acerca de uma horizontalidade em termos de epistemologias musicais e problematizam a concepção de erudição musical.

Por aqui, considerando a possível interface "composição e etnomusicologia" e admitindo as problematizações distintas dessas áreas sobre "música", já parece oportuno promover ponderações breves acerca da acepção e implicação do termo "composição". Primeiramente, clarifica-se que não cabe aos anseios deste artigo emparelhar ou uniformizar o que se entende e como se expressa a criação musical no que diz respeito aos contextos de dentro, de fora da academia e pelo mundo, visto que nem mesmo o sentido de música experienciado no âmbito do Ocidente encontra correlatos em todas as manifestações culturais (PINTO, 2001, p.223). Sendo assim, é importante destacar que composição, como área de conhecimento, refere-se fortemente a uma construção europeia (endossada no universo acadêmico, do concerto e de derivados) mais precisamente marcada a partir da fase final da Idade Média. Esta perspectiva convive com outras, expressas em culturas diversificadas ao longo do planeta, onde não há sequer autonomia e autoria precisamente definidas de processos criativos anteriores a qualquer prática musical.

Segundo: o "compor" diz respeito, aqui, ao domínio das evidências de ações de construção (conscientes/deliberadas ou não) - padrões de relações objetivas e rede de relações subjetivas (REYLNOLDS, 2002, p.3) - em torno dos processos que envolvem o fenômeno da criação/existência de uma obra musical (ou aquilo que pode ser entendido como parte de um repertório musical) - algo relativo ao princípio de obra artística, que prevê uma arquitetura (física ou conceitual) que the confira uma unidade capaz de separá-la do mundo ordinário, incluindo as transgressões dos modelos tradicionais e hegemônicos (OLIVEIRA FILHO, 2014, p.17).

E terceiro: a despeito da característica ocidental ligada à existência da composição como área formal de conhecimento, com todos os seus valores intrínsecos (autoria, originalidade etc.), reconhece-se, no presente trabalho, que, se há um repertório musical, independentemente do horizonte cultural, há também uma teoria musical implícita (BLACKING, 1973, 1995, 2007), como também deve haver um conjunto de princípios inteligíveis que alicerce suas bases criativas, uma espécie de compor que lhe é subjacente, tendo ou não precisões acerca de sua autonomia e autoria.

\footnotetext{
$4 \quad$ Não custa lembrar que, da época de Bartók aos dias presentes, o que se entende por etnomusicologia passou por profundas transformações, as quais inclui a mudança do estudo das culturas e questões musicais ao redor do planeta de um viés simplificador e tendenciosamente etnocêntrico para um viés mais complexo, mediado pelo método etnográfico (ver LÜHNING; TUGNY, 2016).
} 
Preocupações não musicais relativas ao compor são consideradas por Paulo Lima (2005b), após refletir sobre a relação "invenção e memória" e levantar questões ao campo da composição acadêmica: que espécie de educação ou deseducação estamos praticando? Que espécie de comunidade musical estaremos plantando? Que espécie de ideal sonoro? Que espécie de espírito ou de upgrade nos convoca? Sem esboçar respostas definitivas, ele avança dizendo que

\begin{abstract}
Aqui ou na China o nosso problema também é o desafio de compor um discurso. De quebrar a forma, sem perder a ternura. Afinal, somos uma sociedade de cientistas da arte e o gesto pasteurizado das comunicações de pesquisa: proficiente, objetivo e inútil como atitude composicional, não nos edificaria hoje. (LIMA, 2005b, p.23).
\end{abstract}

Curiosamente, em direção similar, Anthony Seeger (2008, p.240) aponta algumas questões preliminares ao campo da etnomusicologia: o que acontece quando as pessoas fazem música? Quais são os princípios que organizam as combinações de sons e seu arranjo no tempo? De onde vem a criatividade musical? Qual o papel do indivíduo na tradição, e o da tradição na formação do indivíduo? Tudo isso como alavanca para a ideia de que música faz parte das estruturas que envolvem as organizações sociais e, portanto, age e sofre ação da dinâmica cultural. Ressalta-se que política, como conjunto de princípios e objetivos que influenciam as tomadas de decisões compreendidas num determinado domínio, complexifica ainda mais a tríade "música - sociedade - cultura".

Essas duas perspectivas apresentadas nos levam a supor que, se etnomusicólogos e compositores decidissem fazer um bolo em conjunto, a "criação musical" seria a cereja, escolhida e cultivada por ambos. No processo de feitura do mesmo, provavelmente os etnomusicólogos estariam mais interessados em saber sobre a procedência dos ingredientes e o seu impacto nutricional, enquanto os compositores estariam interessados nas minúcias de como os ingredientes podem ser combinados a fim de proporcionarem diferentes sabores e situações degustativas. Isto porque, como parece, enquanto o campo da composição enfatiza o fenômeno musical de dentro para fora, a etnomusicologia tende a observá-lo a partir de suas repercussões em seu entorno não estritamente musical (LIMA, 2005b, p.292-303).

Dito isso, parece propício assumir que etnomusicologia

[...] tem como pressuposto o profundo interesse e respeito pela diversidade sociocultural e política de pessoas e grupos que se encontram em posição minoritária frente às hegemonias geopolíticas, vivendo em processos contínuos de expropriação [...]. (LÜHNING; TUGNY, 2016, p.23).

É importante destacar que tal interesse esbarra no conceito de ethnomusicology at home ${ }^{5}$ (NETTL, 2005), que, nas mais variadas localidades, impõe uma transcendência da perspectiva acadêmica da própria área da etnomusicologia, embutindo nela um 5 Termo cujo significado se relaciona com a ideia de "estudo do que está, em algum sentido, no âmbito da nossa própria cultura" (NETTL,
2005, p.480), admitindo em seu bojo diversificados níveis e possibilidades. 
senso de protecionismo que se desmembra em ativismo e ações afirmativas (LÜHNING; TUGNY, 2016, p.26).

Assim, e tomando como hipótese de trabalho o prognóstico de que o gesto pasteurizado das comunicações de pesquisa, proficiente, objetivo e inútil como atitude composicional, não edificaria a atuação acadêmica dos compositores, é razoável perguntar: 1) Em que tipo de engajamento o campo da composição se atrela? 2) Como e a partir de quais estratégias os trabalhos em composição (incluindo a produção de obras) podem responder à dinâmica (at home) dos nossos problemas sócio-político-culturais?

Não caberia aqui o esforço ingênuo de apontar respostas definitivas para essas questões nem, muito menos, supor que as possíveis respostas possam impor limites a qualquer atividade composicional. ${ }^{6}$ Por outro lado, é preciso vislumbrar alguma direção acerca das funções socioculturais e políticas do compor, no sentido de alguma assertiva sobre "o que pode a composição" num contexto de pesquisa (que implica neste artigo) das estratégias criativas de uma concepção musical alheia aos paradigmas ocidentais, os quais, inclusive, legitimaram a composição como área de conhecimento.

Sobre esta demanda, talvez o primeiro ponto a ser abordado é a relação entre composição, arte e pesquisa. Tudo isso passa pelo conceito de pesquisa artística (LÓPEZ-CANO, 2015), mas encontra ecos importantes em Lima, quando diz que

\begin{abstract}
A geração de novas dinâmicas de concatenação de materiais (geralmente sonoros) faz parte daquilo que constitui o objeto mais autêntico de nossa área de pesquisa. O desafio da metodologia de pesquisa em composição envolveria, dessa forma, a proposição de bases racionais a serem utilizadas como referência, tanto pela instância da concatenação de materiais como por sua articulação em linguagem, ou seja, a produção de discurso. (LIMA, 2016, p.13).
\end{abstract}

Quer dizer, para além da "mão na massa" no compor (manipulação dos materiais sonoros) - no caso de um contexto onde suas ações musicais são deliberadas - e a tradução disto para a linguagem escrita (um pré-requisito trivial de muitos dos programas de pós-graduação), existe a dimensão da produção de discurso (PÊCHEUX, 1969, p.82), que projeta no ofício do compor, considerando principalmente o objeto de criação, 0 potencial ilimitado de construção de significados, complexificado nas ocasiões diversificadas de experiência musical (SHAW-MILLER, 2002, p.209).

Portanto, é ponderado afirmar que a música, em sua essência criativa, é capaz de promover ambientes de reflexão, problematizar ideias, desconstruir e reconstruir imaginários acerca do seu entorno não estritamente musical, independentemente de sua suposta vocação narrativa (ALMÉN, 2008; KLEIN; REYLAND, 2013). Nesta direção, e ratificando as concepções de intencionalidade e intervenção presentes na noção de criação musical (BRÜN, 2004, p.77), é viável imaginar que a música (e consequentemente composição) pode assumir um trabalho cultural, como discorre Philip Bohlman (2003), ao discutir a indisposição da teoria em assumir música e cultura conjuntamente: 
[...] Eu gostaria de sugerir que uma das razões dessa resistência à aceitação da proximidade entre música e cultura resulta da paradoxal falta de disposição em admitir a amplitude do trabalho cultural realizado pela música. (BOHLMAN, 2003, p 45-46). ${ }^{7}$

Para o autor, em admitindo a capacidade de influência e interferência da música nas relações e dinâmicas sociais, esta ideia de trabalho cultural é tomada com tanta seriedade que ele avança dizendo que a música, mais que a linguagem, acumula o potencial para articular o poder colonial, e esse potencial nunca foi perdido para aqueles que desejam colonizar os mundos dos outros que encontraram (BOHLMAN, 2003, p.47). Diante desta ideia, o que fica como pressuposto é que, se na música (na composição) habitam ferramentas que dão margens ao ímpeto colonizador a ser exercido no seu potencial de trabalho cultural, nela residem também mecanismos favoráveis aos processos de descolonização, possibilitando assim a visibilidade de outras epistemologias.

Lembremos que, no curso da música de concerto, a quebra do discurso expressivo/composicional nunca se deu de maneira espontânea, ela sempre esteve atrelada ao diálogo dos compositores com outras culturas (FRIDMAN, 2012, p.357). Por exemplo, parte significativa da ampliação do imaginário rítmico e métrico presente nesta perspectiva europeia de música é atrelada a este fenômeno, dirigindo-se a uma complexificação das dimensões de temporalidade musical, sobretudo no que diz respeito às tendências de não linearidade (ver KRAMER, 1988). Neste contexto, os casos de investidas composicionais que se relacionaram com o diálogo intercultural são numerosos e diversificados. Um dos muitos exemplos está em Olivier Messiaen, que, motivado por um encantamento pela cultura indiana, passou a trabalhar sistematicamente com a premissa dos ritmos não retrogradáveis ${ }^{8}$ em suas obras, após um estudo das Deçi-tâlas hindus, ${ }^{9}$ aplicando sobre algumas delas procedimentos de aumentação, diminuição, agregação de valores, dentre outros, como pode ser visto na peça Cantéyodjayâ (1949), para piano solo, em fragmento ilustrado nos exemplos $1 \mathrm{a}$ e $1 \mathrm{~b}$.

\footnotetext{
7 Original: "[...] I wish to suggest that one reason there is resistance to accepting the relatedness of music and culture results from the paradoxical unwillingness to admit to the full range of cultural work that music accomplishes" (BOHLMAN 2003, p.45-46).

8 Também chamados de ritmos palindrômicos, são estruturas de durações que podem ser lidas, indiferentemente, tanto da esquerda para a direita como pelo sentido oposto.

9 Estruturas rítmicas da cultura hindu que são nomeadas, individualmente, numeradas em tabela (total aproximado de 120). Algumas dessas estruturas apresentam a característica da não retrogradação.
} 

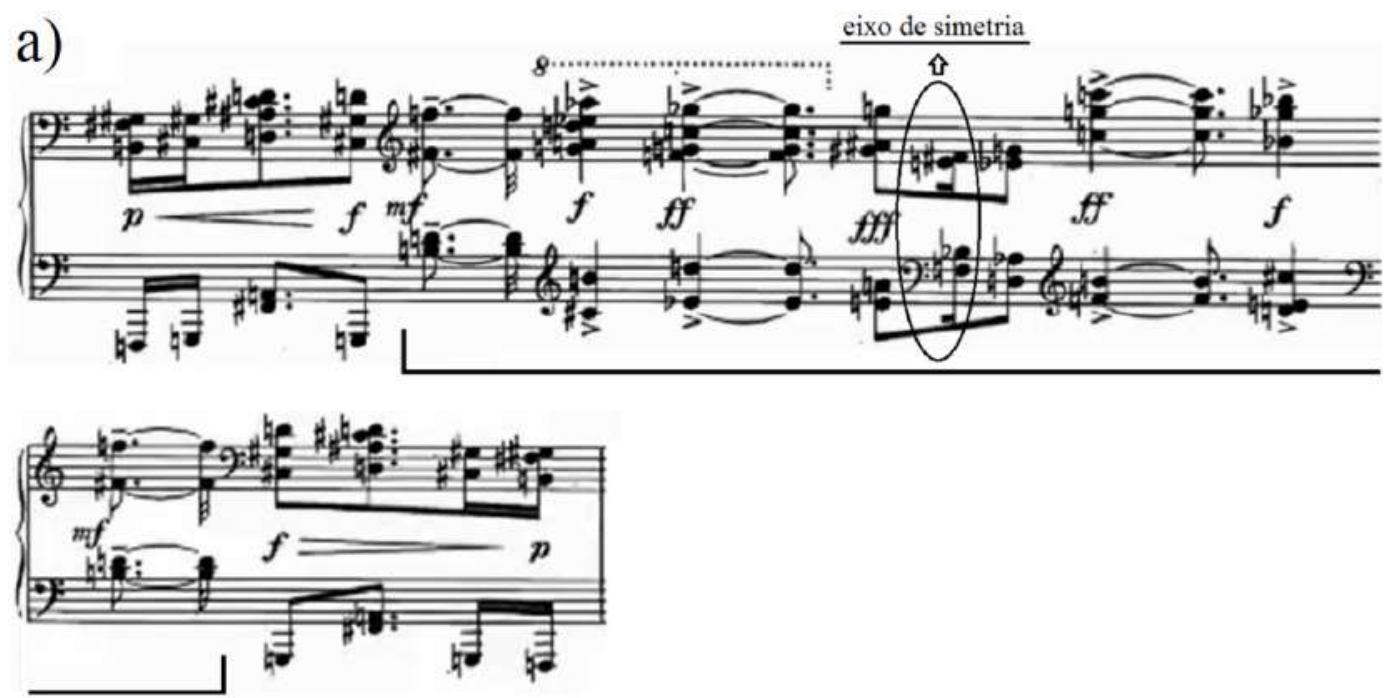

Exemplo 1a: Ritmo não retrogradável, em Cantéyodjayâ

b)

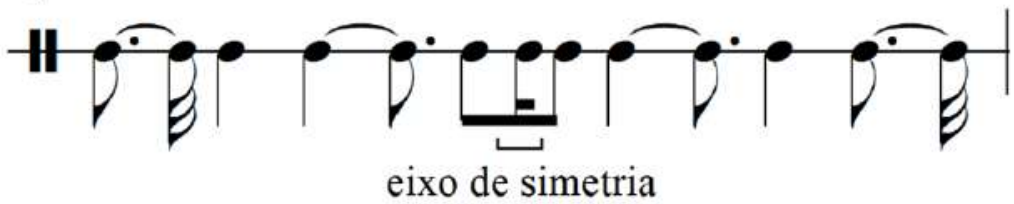

Exemplo 1b: Ritmo não retrogradável (isolado), em Cantéyodjayâ

Considerando o empenho de certos compositores (a exemplo do caso de Messiaen) na transcendência de uma figuração simbólica da música de outra cultura para a implementação de um ambiente sonoro de problematização, envolvendo a disposição à interação e à criação a partir de princípios reguladores das mesmas, é preciso refletir sobre em que medida iniciativas como essa são capazes de dar visibilidade a outras visões de mundo ou, pelo menos, a outras maneiras de lidar com a expressão e criatividade musical. Antes de encarar esse desafio, vale mencionar um caso ainda mais expressivo.

Em 1988 foi composta por Ersnt Widmer o seu opus 169, intitulado de De Canto em Canto II: Possível Resposta. Há algo de muito significativo nesta obra que condensa em seu âmago uma perspectiva ideológica do movimento de composição da Bahia. ${ }^{10}$ Vejamos o que nos diz alguém que acompanhou a sua estreia:

Foi no dia 17 de agosto de 1988 que a peça De canto em canto Il: possível resposta op. 169 foi estreada em Salvador, no Teatro Castro Alves, tendo Ernst Widmer como regente. A peça [...] acolhe a intervenção abrupta e inesperada do grupo

\footnotetext{
10 Denominação associada ao circuito de produção composicional iniciado em 1954 com os Seminários de Música da UFBA, mais tarde englobado pelas atividades ligadas à Escola de Música da UFBA, e que, passados mais de 60 anos, ainda se mantém ativo. Este movimento guarda relações profundas com todo o impulso artístico, sociocultural e político que resultou na formação do Grupo de Compositores da Bahia (GCB), que, nas palavras de Ilza Nogueira (1999, p.28), "é especialmente lembrado pela quantidade de produção, pela originalidade do produto, pelo compromisso com a novidade e com a tradição, pelo envolvimento com a cultura baiana, pela abertura a toda e qualquer expressão cultural, e pela grande influência que exerceu nos programas de ensino, pesquisa e difusão musical daquela Universidade".
} 
carnavalesco, ${ }^{11}$ que se posiciona em forma de semicírculo em torno da orquestra, tocando juntamente com ela. No final da obra, todos os músicos deixam o palco tocando seus instrumentos e se dirigem à entrada do teatro. Ainda lembro com a maior clareza possível essa parte final da performance, uma espécie de celebração que aconteceu no foyer do teatro, com os músicos dos dois grupos circulando e tocando fragmentos da música que havia sido tocada no palco, misturando-se com o público um tanto atônito e deslumbrado que saía da sala de concerto, sem entender muito bem o que estava presenciando. Todo vestido de preto, como regente, mas também usando colares de várias cores típicos do Candomblé da Bahia, Ernst Widmer também participou da performance. Ele circulava pelo espaço, misturando-se com os músicos, como se ainda estivesse regendo a peça, olhando de forma fixa na direção do horizonte. (LIMA, 2019, p.43).

Observa-se que, não bastasse o empenho do compositor em integralizar orquestra sinfônica e Afoxé Filhos de Gandhi ${ }^{12}$ num projeto artístico que admitia possíveis conflitos e incongruências (de sonoridades e perspectivas musicais), a peça ainda revela em seu tecido ideológico e estrutural simbolismos preciosos acerca de seu discurso. 0 primeiro é a referência à obra The Unanswered Question, de Charles Ives, que aparece não apenas problematizada no subtítulo (Possível Resposta), mas também no aproveitamento de seus materiais compositivos; o segundo é a própria utilização do afoxé, na sua formatação orgânica, imprimindo toda sua ambiência rítmico-temporal, que revela uma cosmovisão africana, e que se apresenta a partir do quarto dos cinco movimentos como uma resposta/consequência do fluxo dramático tecido até então; e, talvez mediando essas duas instâncias/entidades, fragmentos melódicos da Sinfonia n. 9, de Anton Bruckner, que tem como uma de suas principais marcas a dedicatória a Deus.

O que Widmer queria com essa engenharia conceitual pode ser imaginado a partir de suas próprias palavras, quando diz: "Não sei se existe a resposta que Charles Ives se refere, mas talvez quem dê a resposta sejam os Filhos de Gandhi" (apud LIMA, 1999, p.30). Quer dizer, uma declaração imprecisa, mas que, por detrás das suas implicações metafísicas, aponta para caminhos de reflexão múltiplos e convergentes: a relatividade do saber/conhecimento, frente a uma evidente pluralidade epistêmica, e a noção de tolerância enquanto ferramenta social construtivista podem ser alguns deles. Ideias, certamente, dificílimas de serem implementadas sob o ponto de vista polarizado das partes (seja a orquestra ou o afoxé, com seus idiomas e sotaques específicos), o que confere ao compositor o mérito de empreendimento do encontro/diálogo, trazendo à tona seus possíveis substratos.

Diante das argumentações tecidas até aqui e revisitando a noção de problema composicional (OLIVEIRA, 1992), percebe-se que há no compor da música de concerto uma espécie de permissividade ao conflito de ideias e aos consequentes diálogos quando este é eficientemente engendrado. Esta disposição parece caminhar num estágio de maturação ainda não alcançado no âmbito social, o que se afina com a perspectiva de

\footnotetext{
11 Referindo-se ao Afoxé Filhos de Gandhi.

12 Um dos afoxés mais tradicionais do carnaval de Salvador (BA), constituído basicamente por homens trajados de turbantes e vestes brancas, criado em 1949 com o ímpeto de manutenção de tradições religiosas africanas, espalhando mensagens de paz inspiradas no líder indiano Mahatma Gandhi.
} 
constituição do novo cristalizada na criação artística, expressa em Cornelius Castoriadis (2000), e legitima a sua capacidade em realizar um trabalho cultural (BOULMAN, 2003). Esse potencial chancela assertivas relativas ao ofício composicional, no sentido de abordagens reflexivas em termos de estudos culturais. Portanto, a composição (como pesquisa e como arte) poderia ser tomada como um instrumento de tradução intercultural.

A tradução intercultural alia-se à noção de tradução de saber e consiste no trabalho de interpretação entre duas ou mais culturas, com a premissa prioritária de identificar preocupações comuns, aproximações complementares, bem como contradições inultrapassáveis (SANTOS; MENEZES, 2009). Esta atividade tem o potencial de deslocar dispositivos de poder, visto que traz à tona novas possibilidades de compreensão de um dado assunto - "em sua condição híbrida de entrelaçamentos, pode gerar a articulação de ideias e conceitos, dentro de sistemas sociais rígidos institucionalizados" (GUGGISBERG, 2016, p.134) -, o que embute nela a vocação de alterar quadros de invisibilidade acerca de fazeres e saberes coletivos.

Foi a partir da noção de trabalho cultural, via perspectiva de tradução intercultural, que as cinco obras a serem analisadas em algumas de suas situações compositivas buscaram um diálogo com a epistemologia musical da cultura do candomblé, tendo em vista, mais que uma revelação, uma problematização propositiva de seus processos rítmicos.

\section{O compor da música de candomblé em cinco processos rítmicos ${ }^{13}$}

Grosso modo, o candomblé é uma manifestação cultural complexa de origens africanas, desenvolvida no Brasil. Segundo Edison Carneiro,

Embora eminentemente religioso e constituído por papéis hierarquizados de homens e mulheres, o candomblé assume sua vocação de reunir e de manter memórias remotas e outras próximas, referenciando culturas, idiomas, códigos éticos e morais, tecnologias, culinária, música, dança, entre tantas outras maneiras de manter identidades, de situar e manifestar cada modelo, nação. (CARNEIRO, 2008, p.XIV).

Sua música existe a partir de uma formação instrumental comumente restringida a um quarteto constituído de três atabaques e uma campana, que possibilita expressões puramente instrumentais, mas que também serve de sustentação para vozes. Os três tambores possuem afinações, funções e nomes distintos. $O$ atabaque rum é o maior, mais grave e de utilidade solística, enquanto os outros dois, o rumpi, de registro médio, e o lé, o mais agudo, obedecem ao papel de acompanhamento. A campana, neste caso chamada de $g \tilde{a}^{14}$ está sempre encarregada de repercutir padrões específicos de time-line,$^{15}$ os quais se apresentam de maneira variada nos atabaques rumpi e lé.

\footnotetext{
13 As bases desta seção estão alicerçadas em Amaro e Lima (2016), onde se pode compreender com mais detalhe as suas direções metodológicas.

14 Este instrumento, com raridade, pode ser dobrado por um chocalho.

15 Também chamados de "claves" ou "toques", são padrões rítmicos cíclicos e acelerados, caracterizados frequentemente por uma estrutura interna assimétrica, como 5 + 7 ou 7 + 9 (ver KUBIK, 2010a, p.42-46; LÜHNING, 1990).
} 


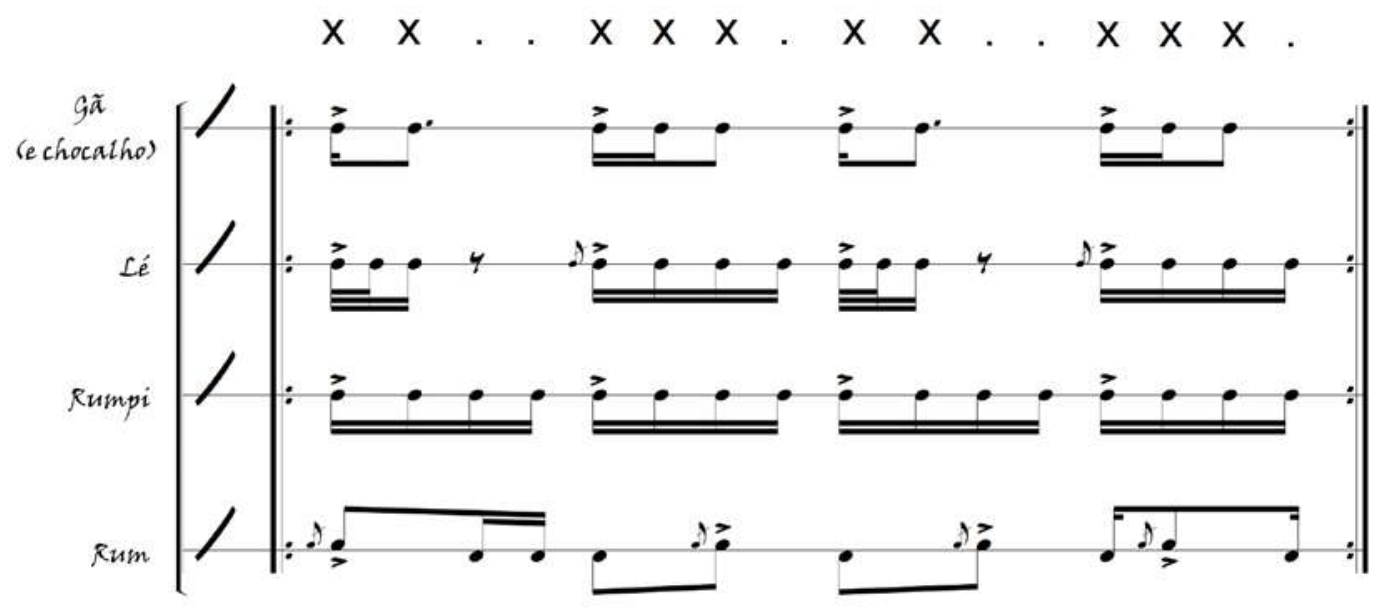

Exemplo 2: Ritmo agueré, no candomblé

O exemplo 2 ilustra uma possibilidade comum ${ }^{16}$ do toque de candomblé agueré, associado ao orixá Oxóssi. Com este toque, pode-se compreender como ocorrem as atuações instrumentais do seu conjunto musical: o gã, como sempre, se encarrega de sustentar temporalmente, com precisão e proeminência, a clave (time-line) em questão, de onde derivam todas as implicações rítmicas repercutidas nos outros instrumentos; os atabaques rumpi e lé sempre apresentam uma espécie de variação da clave que, no mesmo instante que evidencia o seu ciclo numérico de pulsos, reforça seus pontos específicos de acentuação, os quais determinam suas seções agrupacionais - em muitas ocasiões, eles tocam o mesmo material musical (variando apenas em termos de registros), contudo, quando tocam coisas diferentes (como é o caso do exemplo 2), o rumpi tende a reforçar os pulsos, enquanto o lé, uma "versão" mais "movida" da clave; e o rum sola entre frases rítmicas determinadas e outras improvisadas (de acordo sempre com a dança das filhas de santo e a manifestação dos orixás - entidades de culto), promovendo ao resultado sônico expressões diversificadas, que estão para além das previsões de conjuntura do todo rítmico restrito à organização da clave.

Sobre esta instrumentação, há ainda detalhes importantes a serem reforçados. Os atabaques ocupam uma posição de destaque, pois são considerados essenciais para a invocação dos orixás - tais instrumentos funcionam como ferramentas de mediação entre as dimensões humana e espiritual. Dentre eles, o rum ainda ocupa uma posição hierárquica superior, pois é a partir do seu desempenho que o orixá em questão é gradualmente manifestado, e depois de manifestado desenvolve um diálogo intenso a partir da dança. Numa concepção de subserviência ao teor improvisatório do Rum, os outros dois atabaques (em uníssono ou com variações rítmicas sutis de um para o outro), juntos ao gã, tendem a implementar uma atmosfera rítmica cíclica e com características agrupacionais ${ }^{17}$ e de acentuação condizentes com a individualidade e personalidade do

16 Um mesmo toque de candomblé pode apresentar leves diferenças, a depender da casa ou nação de referência.

17 Referente à noção de agrupamento vistas nas teorias do ritmo, como, por exemplo, em Cooper e Meyer (1960), Cone (1968), Berry (1976), Epstein (1979) e Lerdahl e Jackendoff (1987). 
orixá ao qual a música é dedicada, sempre determinada por uma clave ${ }^{18}$ específica que se mantém inalterada durante toda a canção.

É do antagonismo entre a perspectiva temporal não linear (KRAMER, 1988), cíclica ou circular (ou espiral) - imposta pelos time-lines (expostos no gã, e de maneira variada nos atabaques de acompanhamento) - e o consistente perfil de temporalidade linear (KRAMER, 1988) referente à trajetória direcional que envolve o desenvolvimento rítmico narrativo das improvisações de Rum que situações de polirritmia se afloram. E foi a partir da observação dos modos de interação entre estes instrumentos que cinco processos de desenvolvimento rítmico foram identificados como estratégias compositivas recorrentes no tipo de música em questão. ${ }^{19}$

\subsection{Ressignificação rítmica}

Ressignificação rítmica é definida como a transformação ou, simplesmente, mudança da perspectiva intuitiva de um evento rítmico de grande evidência, desencadeada pela ação de outro evento de menor expressão, cuja função é, exatamente, promover novas feições e expectativas.

O exemplo 3 ilustra quatro recortes da transcrição de uma gravação denominada de Adarrum de Ogum. Em todos é possível perceber o mesmo material rítmico: a clave vassi, entoada pelo gã e reforçada pelo caxixi e atabaques rumpi e lé - estes últimos apresentando uma variação que expõe os principais pontos de acentuação do toque, os quais marcam a sua divisão agrupacional assimétrica $(5+7)$. Por outro lado, observa-se também que em cada excerto a clave é submetida a atuações diversificadas do rum, que implicam diferenciações de seu significado rítmico natural, visto que projetam nela pontos de acentuação não previstos em sua estrutura básica, criando versões sonoras "renovadas". Se em 3b e em 3c o rum atua na manipulação da sensação do ponto de iniciação do ciclo rítmico da clave - acarretando feições diferenciadas (rotacionadas) da mesma -, em 3a este mesmo instrumento propõe a ela um ambiente de síncopes, e em 3d subverte a sua perspectiva métrica. Assim, o rum consegue promover diferentes impulsos de ordem rítmica, capazes de alterar a maneira como o padrão rítmico principal da música é percebido, fazendo com que ele seja intuído de maneiras sortidas.

18 Existe uma grande quantidade de toques ou claves no contexto do Candomblé. Parte deles e suas especificidades podem ser vistas no capítulo 6 de Cardoso (2016).

19 Pondera-se que a dimensão criativa na música de candomblé não passa por instâncias de autonomia e autoria bem definidas. 


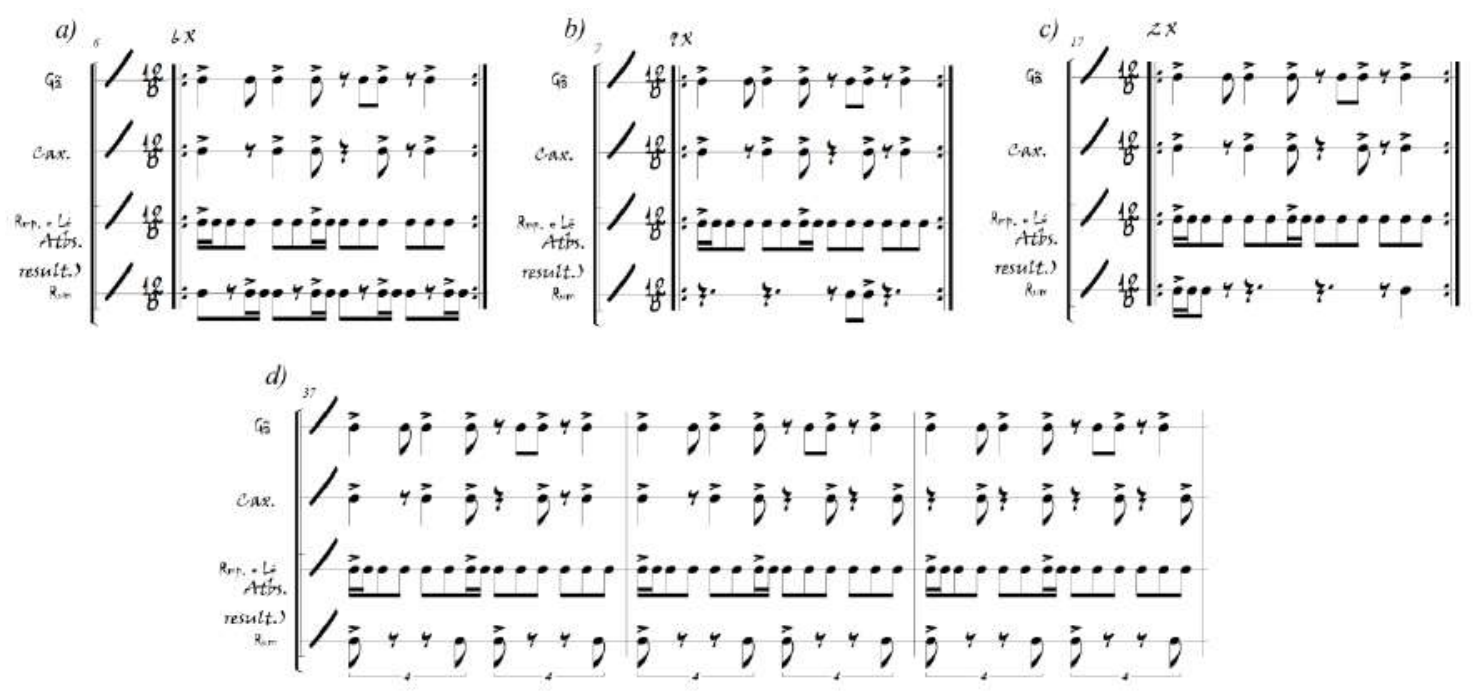

Exemplo 3: Ressignificação rítmica

\subsection{Dissociação rítmica}

Dissociação rítmica é definida como um desprendimento, acompanhado por um progressivo desenvolvimento do membro de um evento rítmico formado a partir de uma verticalidade (sobreposição de materiais), resultando em dois ou mais caminhos rítmicos paralelos: o reminiscente do evento rítmico primário e o(s) resultante(s) do processo de desmembramento.

No exemplo 4 (transcrição da gravação do toque runtó) é possível perceber a recorrência de uma realização composicional que se consuma através duma progressão entre "juntos" e "separados". Observa-se um evento rítmico conciso (c. 1, marcado em caixa azul) formado pela sobreposição de três materiais afins, correspondente à junção das partes do gã e dos atabaques rum, rumpi e lé. Ao longo de poucos compassos que se sucedem, um membro do evento mencionado, o relativo ao material do atabaque rum, desprende-se gradualmente do "todo" (linha vermelha), assumindo características próprias e, assim, constrói um caminho contrapontístico paralelo que interage com o evento primário, ainda sustentado pelos outros atabaques e o gã, que permanecem ciclicamente inalterados. Assim, o rum desmembra-se ritmicamente do conjunto, assumindo progressivamente a função de solista, propondo, inclusive, dissonâncias rítmicas que enfatizam a polirritmia de todo o contexto, até que alcança certa independência (c. 4) - o processo é repetido (c. 5-9), com variantes significativas. 

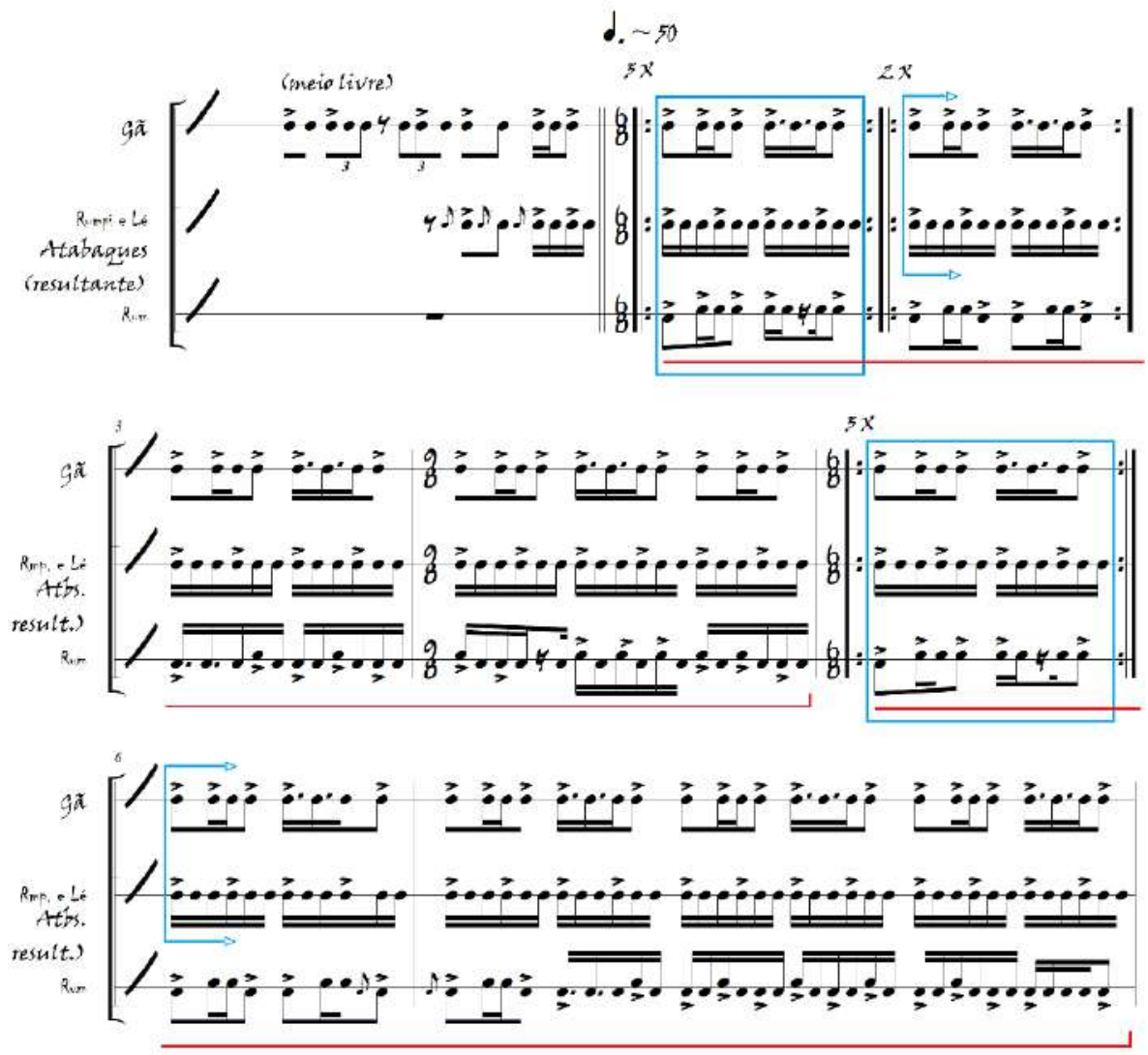

Exemplo 4: Dissociação rítmica

\subsection{Sintonização rítmica}

Sintonização rítmica é um ajuste vertical de materiais rítmicos desiguais, no que diz respeito às suas estruturas agrupacionais e de acentuação, que outrora estavam sobrepostos a partir de uma perspectiva polirrítmica, e que passam, então, a compartilhar do mesmo princípio motívico e estrutural.

O exemplo 5 (transcrição da gravação do toque Igbin) ilustra esta abordagem com clareza. Nota-se uma espécie de ajuste súbito que homogeneíza todas as figurações rítmicas dispostas verticalmente, outrora participantes de uma construção desigual, tendida à polirritmia. Esse ajuste se estabelece como algo em prol da regularidade e é motivado por uma instabilidade em termos de projeções métricas (HESTY, 1997). É possível perceber um composto polirrítmico de doze pulsos e longitudinalmente irregular (c. 5-9), que é transformado em um composto homorrítmico e regular (c. 11-13, marcado em caixa vermelha), como se as figurações temporais entrassem em sintonia. Tal transformação é motivada por um pequeno ponto de tensão (c. 10), provocada por uma alteração de projeção métrica que frustra a sensação de continuidade de ciclos longitudinais de 12 pulsos, estabelecida anteriormente. Em suma, o que se destaca com relevância nas dimensões auditiva e analítica é uma mudança abrupta de texturas que 
implica na passagem direta de um contexto sonoro de estruturas rítmicas desiguais para outro, onde há uma espécie de emparelhamento rítmico.

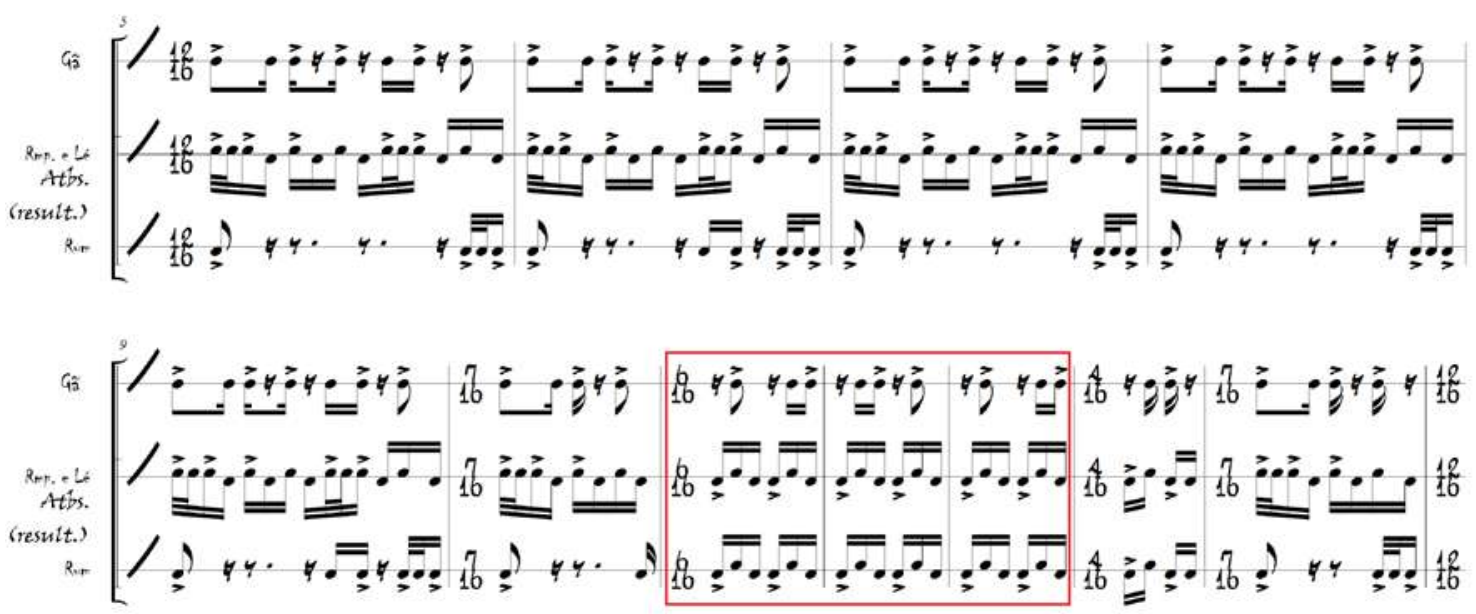

Exemplo 5: Sintonização rítmica

\subsection{Suspensão rítmica}

A suspensão rítmica é a construção de um estado de tensão provocado pela ausência de resposta a um estímulo ou impulso rítmico, resultante do não cumprimento de uma expectativa alimentada por evidências rítmicas precedentes.

No exemplo 6 (transcrição da gravação do toque Oquele), percebe-se que é a partir deste recurso que o rum executa um motivo simples e de muita contundência (círculos azuis), no sentido de marcar precisamente o início dos ciclos rítmicos identificados na clave executada pelo gã e repercutida no rumpi e no lé, gerando uma expectativa de recorrência que é várias vezes cumprida. Subitamente, o rum cessa a execução deste motivo (trecho marcado em linha vermelha), gerando uma tensão justificada pela frustração de expectativa de manutenção deste material, colocando-o em estado de latência. Nessa direção, a sensação de ciclo que estruturalmente ainda permanece em voga com a atuação do gã, do rumpi e do lé passa por um período de grande instabilidade, que é experienciada na dimensão auditiva, tendendo fortemente à promoção de um estado de ansiedade e funcionando como uma articulação cadencial. 


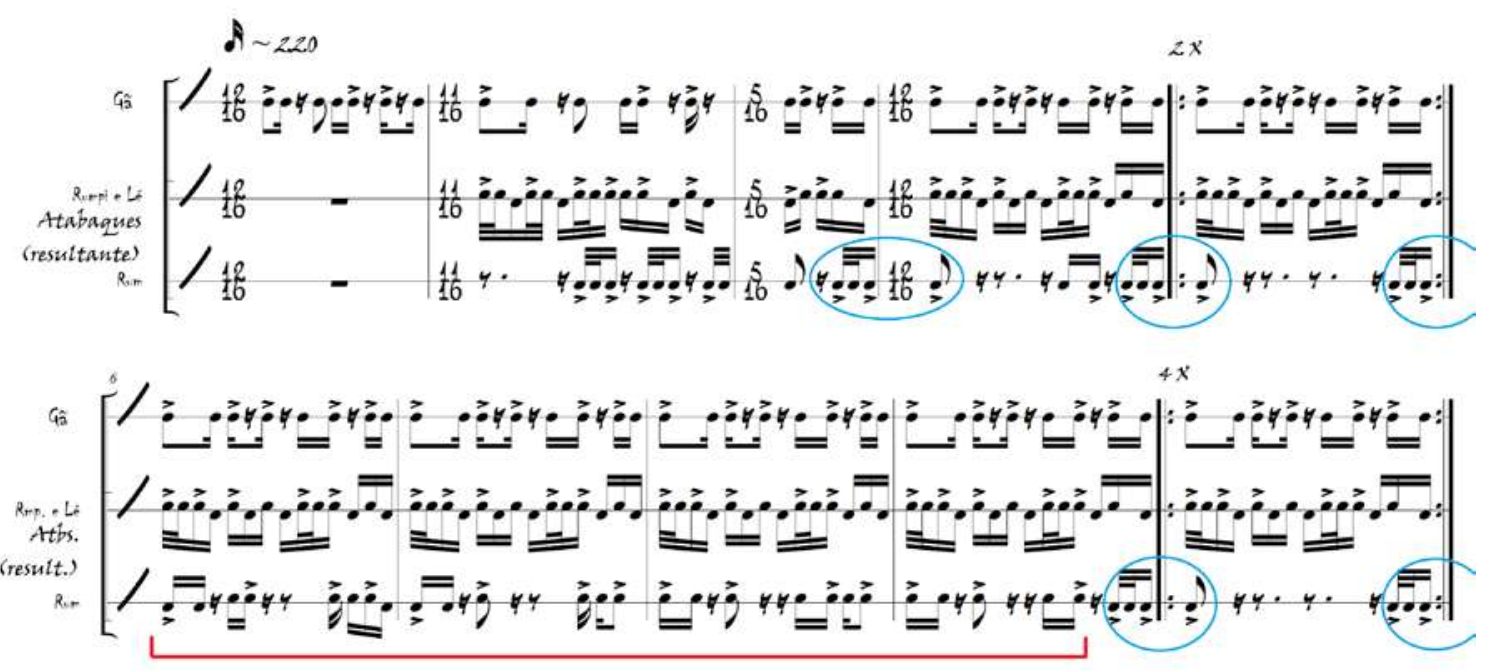

Exemplo 6: Suspensão rítmica

\subsection{Sublimação rítmica}

Sublimação rítmica é definida como a mudança abrupta para uma perspectiva rít$\mathrm{mica} /$ temporal consideravelmente distinta, motivada por um evento rítmico pontual.

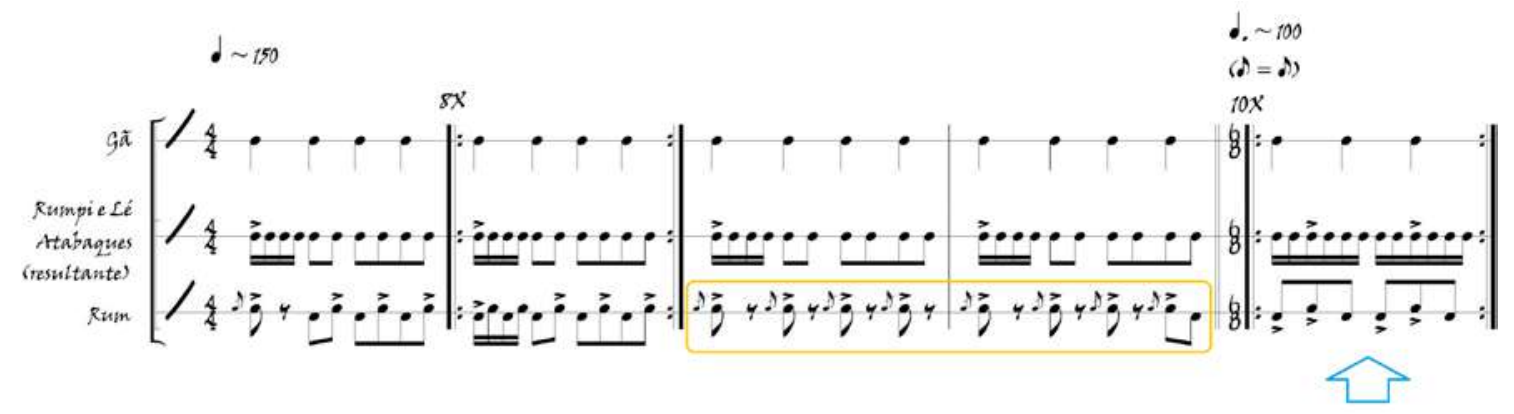

Exemplo 7: Sublimação rítmica: um segundo exemplo

No exemplo 7 (transcrição da gravação do toque Adarrum) observam-se duas perspectivas rítmicas consideravelmente distintas e suficientemente contrastantes: a primeira (c. 1-4) orientada por um fluxo temporal linear de pulso simples - com uma figuração da linha de rum que, reforçada pelas linhas de rumpi e lé, projeta um caminho de acúmulo de energia para os primeiros tempos de cada compasso -, e a segunda (c. 5, seta azul), de pulso composto e essência temporal circular, embora com atividade rítmica atenuada e conflito métrico interno - haja vista o efeito de hemíola provocado pela implicação binária do gã contra a atuação ternária de todos os atabaques -, o que impõe uma sensação de aceleração no andamento. Na perspectiva auditiva, este processo inspira uma mudança abrupta de sensações musicais, sem que haja nenhum tipo de transformação progressiva, embora seja motivada pela atuação do rum, que articula uma "chamada rítmica" (caixa amarela, c. 3-4), como se o "estado" rítmico/temporal passasse por um processo de sublimação. 


\section{Ações artísticas: a reverberação da interface em cinco obras}

A partir da problematização conceitual e compositiva dos processos rítmicos descritos, cinco obras foram compostas: 1) Dakunohrum; 2) Como Brisa nas Costas de Santos; 3) Impulsos; 4) Lapsos de um Encontro; e 5) Ecos n. 3 (sobre o primeiro impulso). Um dado importante a ser considerado sobre elas é que todas foram feitas sob encomenda ou colaboração, sendo algumas a partir de exigências peculiares, o que implicou uma diversidade de temáticas abordadas.

\subsection{Do impulso poético à concepção das obras}

O pensamento composicional das obras foi simpático ao esquema de Roger Reynolds (2002). Nesta direção, três níveis de abstração foram criteriosamente definidos na montagem de cada projeto musical e, em geral, hierarquizados como está disposto no exemplo 8.

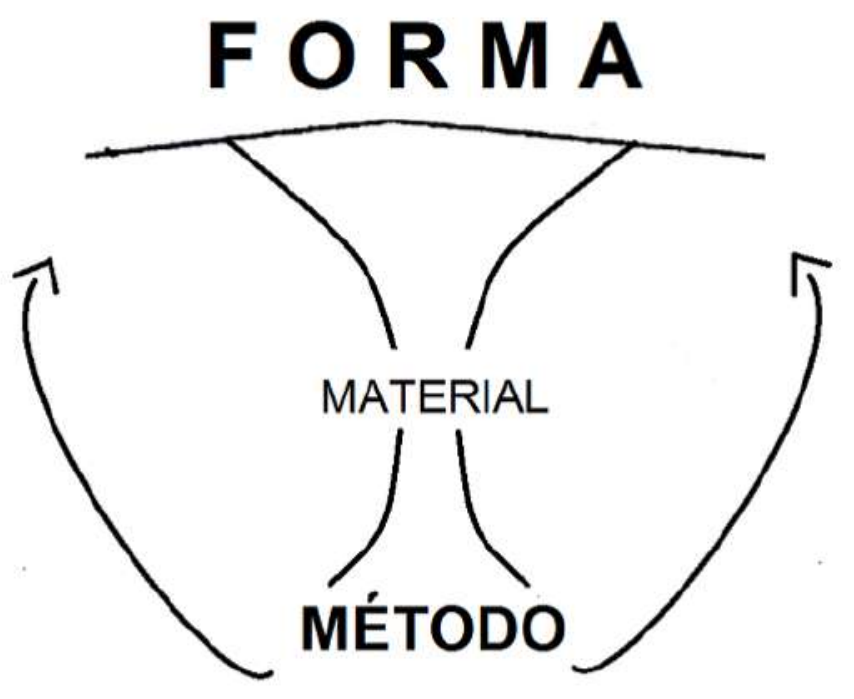

Exemplo 8: Abstração do pensamento composicional das obras

Desta maneira, a "forma" sempre foi pensada logo de saída, e, das vezes que houve surpresa acerca de algum impulso criativo no nível dos materiais, seja via intuição ou intenção dirigida ao aproveitamento de algum material específico (como ocorreu com alguns ritmos do candomblé), refletiu-se como ele poderia responder à composição como um todo (à sua "forma"). Este perfil global das obras, a própria "forma", foi planejado com certo rigor e poeticamente regido por um discurso narrativo inspirado em tramas autorais, algumas das quais se restringiam a um universo estritamente sonoro - as entidades musicais constituídas representavam elas mesmas, e não algo objetivamente associado ao mundo "extramusical" -, como acontece em Impulsos. ${ }^{20}$ 
Logo após o estabelecimento de uma estrutura formal, as atenções eram voltadas ao nível dos materiais, que foram selecionados sem nenhum critério específico e em momentos diversos de cada processo composicional, mas sempre com uma tendência à escolha de ideias rítmicas que participassem do imaginário musical afro-baiano ou texturas, gestos, conjunto de alturas, dentre outros aspectos associados ao imaginário da música de concerto contemporânea e ao rock progressivo, ou seja: traços identitários da minha personalidade. Peças como Como Brisa nas Costas de Santos e Lapsos de um Encontro exigiram uma atenção voltada à coleta de materiais relativos a outros horizontes culturais, pelas razões que serão observadas na seção destinada à abordagem analítico-descritiva de cada obra.

O nível do método é o que especialmente nos interessa no âmbito desta discussão. É onde, de fato, os materiais são manipulados de modo a servir à composição em sua totalidade. É nele onde são localizadas as estratégias que giram em torno das implementações dos processos rítmicos identificados no candomblé, e é por onde foi pretendido expor e, quem sabe, traduzir o aspecto compositivo de uma outra epistemologia musical, sempre numa perspectiva dialógica - o compor da música de concerto como o compor que há na música de candomblé, segundo o meu olhar, formando o meu próprio compor, no sentido do cumprimento dos desafios demandados para e por cada peça.

É importante destacar que os processos rítmicos identificados na música de candomblé sempre foram utilizados para implementar situações expressivas condicionadas pela poética das obras, o que significa dizer que eles não foram aplicados arbitrariamente, e que, na individualidade de cada peça, seus usos foram variados e com importâncias desiguais. Por exemplo: em Dakunohrum, apenas dois processos foram empregados, dentre os quais a noção de ressignificação rítmica protagoniza a seção da obra mais longa e de maior impacto dramático; e a aplicação da sublimação rítmica ocorre de maneiras distintas, quando se compara Impulsos e Lapsos de um Encontro com Ecos n. 3 nas duas primeiras, este processo é utilizado para a articulação sucessiva de contrastes, enquanto, na última, para a delimitação de estruturas formais de média e longa escala.

Na seção 4.2, cada peça, de acordo com a sua posição cronológica de criação, será abordada segundo as suas singularidades e discutida sob um viés analítico que revelará, numa média de três exemplos objetivos, suas situações composicionais mais relevantes e recorrentes. ${ }^{21}$

\footnotetext{
posições. Não há no meu processo a expectativa, talvez ingênua, de um entendimento das mesmas no âmbito das experiências de escuta dos ouvintes, por mais que eu me esforce para dar conta de tendências interpretativas, levando em consideração alguns aspectos objetivos da percepção musical culturalmente compartilhados.

21 A ideia de expor situação distintas de obras distintas, e não uma obra em sua integralidade e detalhes cronológicos, passa pala intenção de demonstrar como os processos apreendidos do candomblé são polivalentes e potencialmente úteis em projetos composicionais diversificados.
} 


\subsection{As obras e suas situações analíticas}

\subsubsection{Dakunohrum}

Das cinco obras apresentadas neste trabalho, talvez seja essa a que considero a mais representativa e que guardo com certa distinção. Seu nome diz muito sobre a pesquisa que a envolve: dentre outros significados atrelados, dakun, em iorubá, equivale a um pedido respeitoso de licença; Dakunohrum (dakun + oh + rum), portanto, é um jogo de palavras que, juntas, representam um pedido de licença ao atabaque rum, no sentido de uma permissividade de diálogo com o seu suposto saber simbólico. A peça foi escrita para 14 percussionistas, a pedido do percussionista Jorge Sacramento, para ser estreada no VII Festival de Percussão 2 de Julho.

Existe uma razão clara para o lugar de destaque desta peça: dentre as cinco, essa é a única construída a partir de uma representação metafórica de sensações e emoções específicas de minha experiência com a pesquisa de campo - uma espécie de autoetnografia. ${ }^{22}$ A primeira vez que adentrei no Terreiro do Gantois e a primeira vez que fui a uma festa pública de candomblé denotam uma sequência de etapas e sentimentos que podem ser expressos em: 1) a perplexidade para com o novo, controlada por uma postura investigativa que me exigia alguma neutralidade analítica; 2) a contenção de momentos muito precisos onde eu me via participando da manifestação cultural (curtindo suas peculiaridades musicais), pois achava que era preciso voltar ao "eu pesquisador" objetivo e imparcial; 3) a impressão sutil de que era possível compreender a complexidade do "novo" através da abordagem crítica de seus elementos individuais constitutivos; 4) a percepção intuitiva de que a subjetividade e uma experiência mais orgânica também poderia ser uma estratégia metodológica de compreensão dos fenômenos observados; e 5) a racionalização de tudo que foi vivenciado. É essa experiência que delineia a estrutura formal de Dakunohrum, impondo à mesma uma representação narrativa metaforizada na construção das texturas e intenções de caráter que determinam suas seções.

No trecho que corresponde à sua primeira grande seção da obra (c. 1-37), observa-se uma alternância estratégica de texturas contidas, de sensação temporal imprecisa e de tendência não linear, tal como é ilustrado no exemplo 9 (vide a atmosfera sonora implementada pelos trêmulos dos teclados, os ataques de sinos tubulares e glockenspiel que anulam qualquer causalidade métrica, e a improvisação pautada em interpretações gráficas realizada pelo berimbau); e outras de muita intensidade e precisão rítmica, com implicações métricas bem definidas, com linearidade temporal objetiva e que incitam a movimentação corporal (exemplo 10). Este jogo de idas e vindas desses dois tipos de manifestações musicais simboliza metaforicamente o ambiente reflexivo evocado pela necessidade de frieza e serenidade analítica para com a observação de fatos experien-

\footnotetext{
22 Em 1975, o antropólogo Karl G. Heider foi um dos primeiros autores a utilizar o termo "autoetnografia" ao se referir às descrições que o grupo humano o qual estudava fazia de sua própria cultura - um conceito que abre margens para concepção de produções artísticas que, de uma maneira direta, refletem sobre experiências particulares de seu(s) autor(es) (CANO; OPAZO, 2014, p.149).
} 
ciados em algumas situações da pesquisa de campo e o despertar progressivo, algumas vezes contestado pela racionalidade imposta pelo "eu pesquisador", de uma vivência mais orgânica e intuitiva dos mesmos fatos.

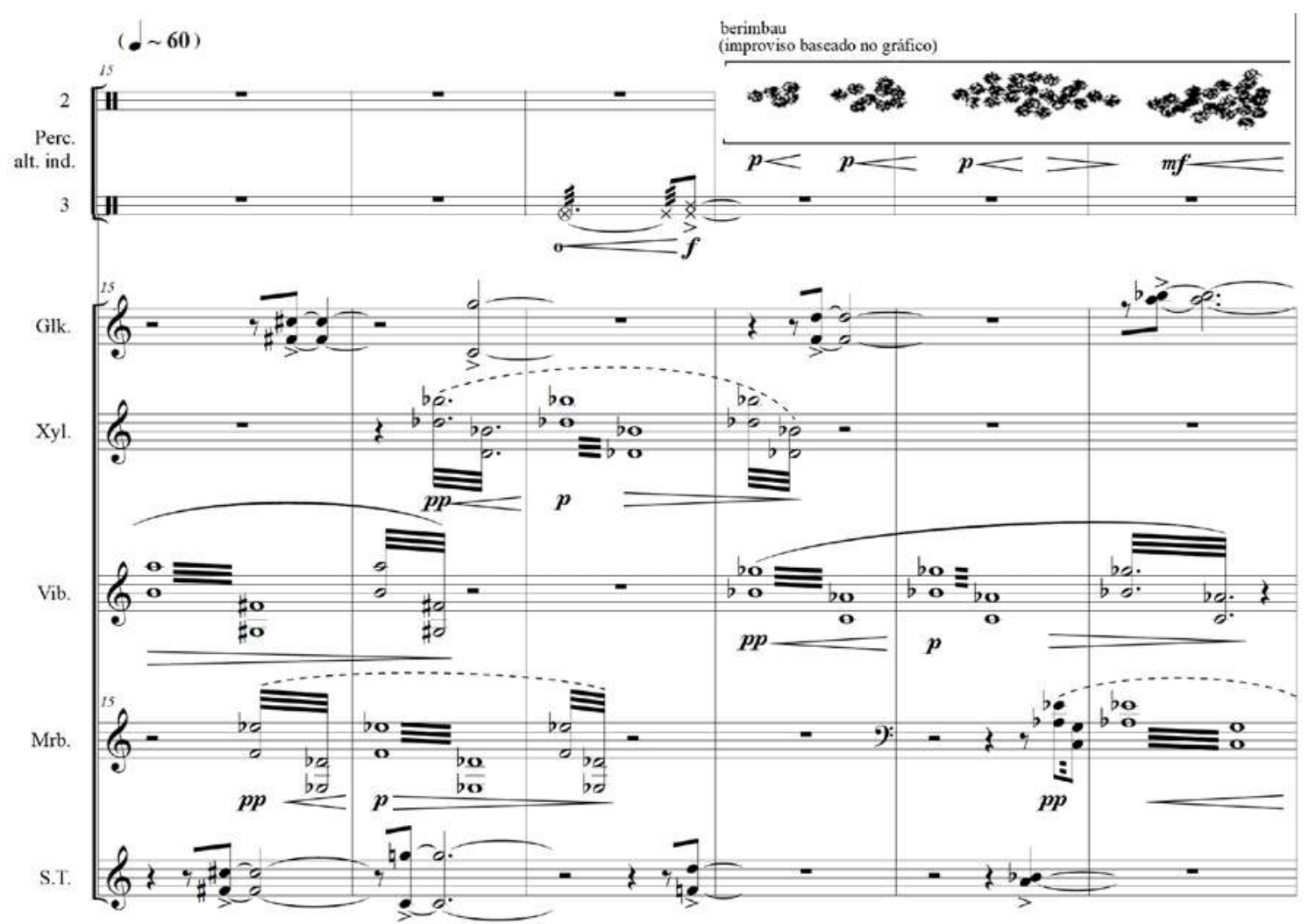

Exemplo 9: Atmosfera não linear, em Dakunohrum 


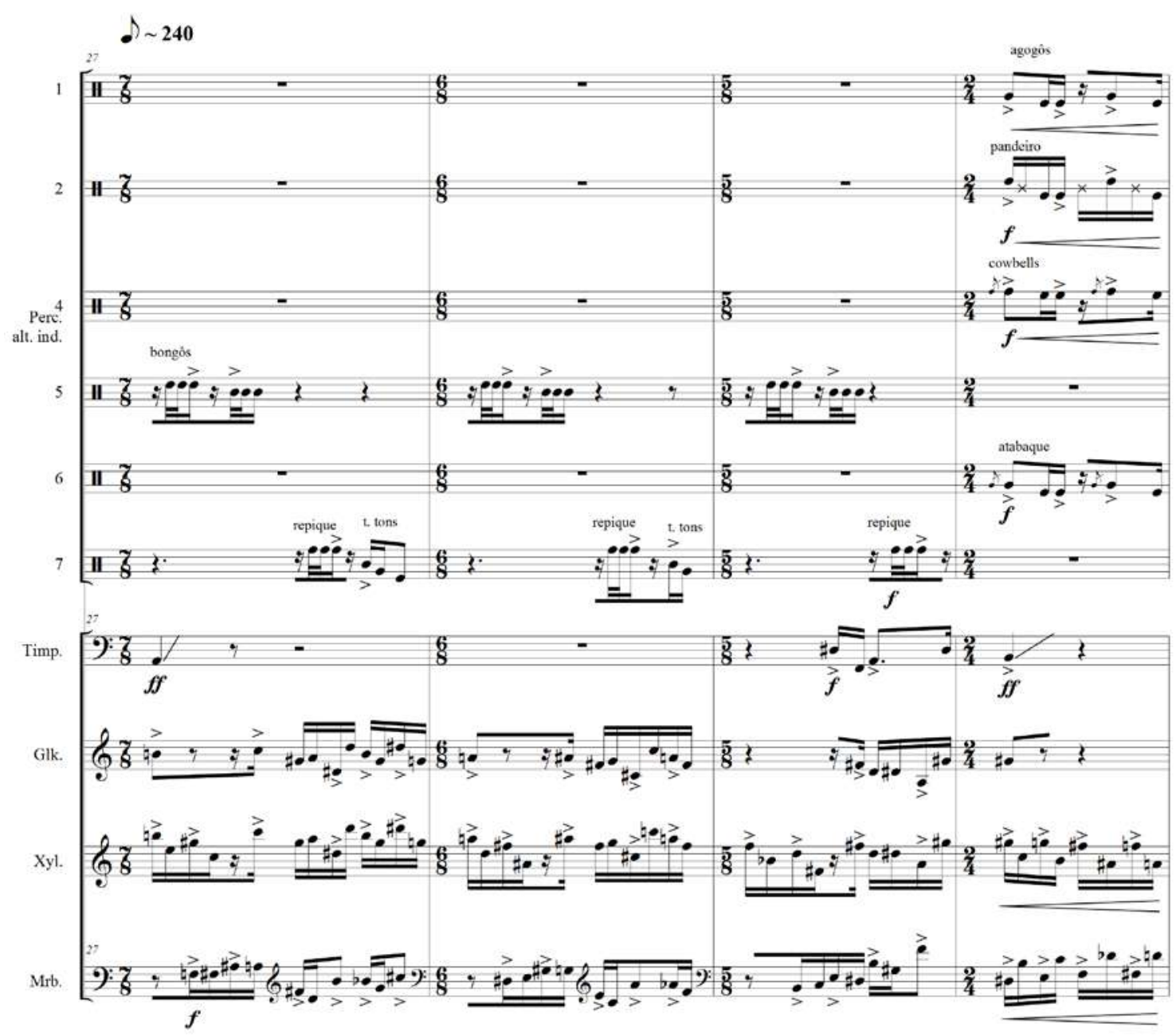

Exemplo 10: Texturas lineares, em Dakunohrum

A "impressão sutil de que era possível compreender a complexidade do 'novo' através da abordagem crítica de seus elementos individuais constitutivos" também aparece transfigurada na trama musical de Dakunohrum. Umas das seções intermediárias (c. 38-47) toma esta ideia como motivação para a construção de um grande gesto onde materiais musicais autossuficientes em suas particularidades são progressivamente aninhados numa engrenagem modular de repetição, dando origem a uma textura confusa, complexa e cheia de energia, tal como está ilustrado no exemplo 11. 


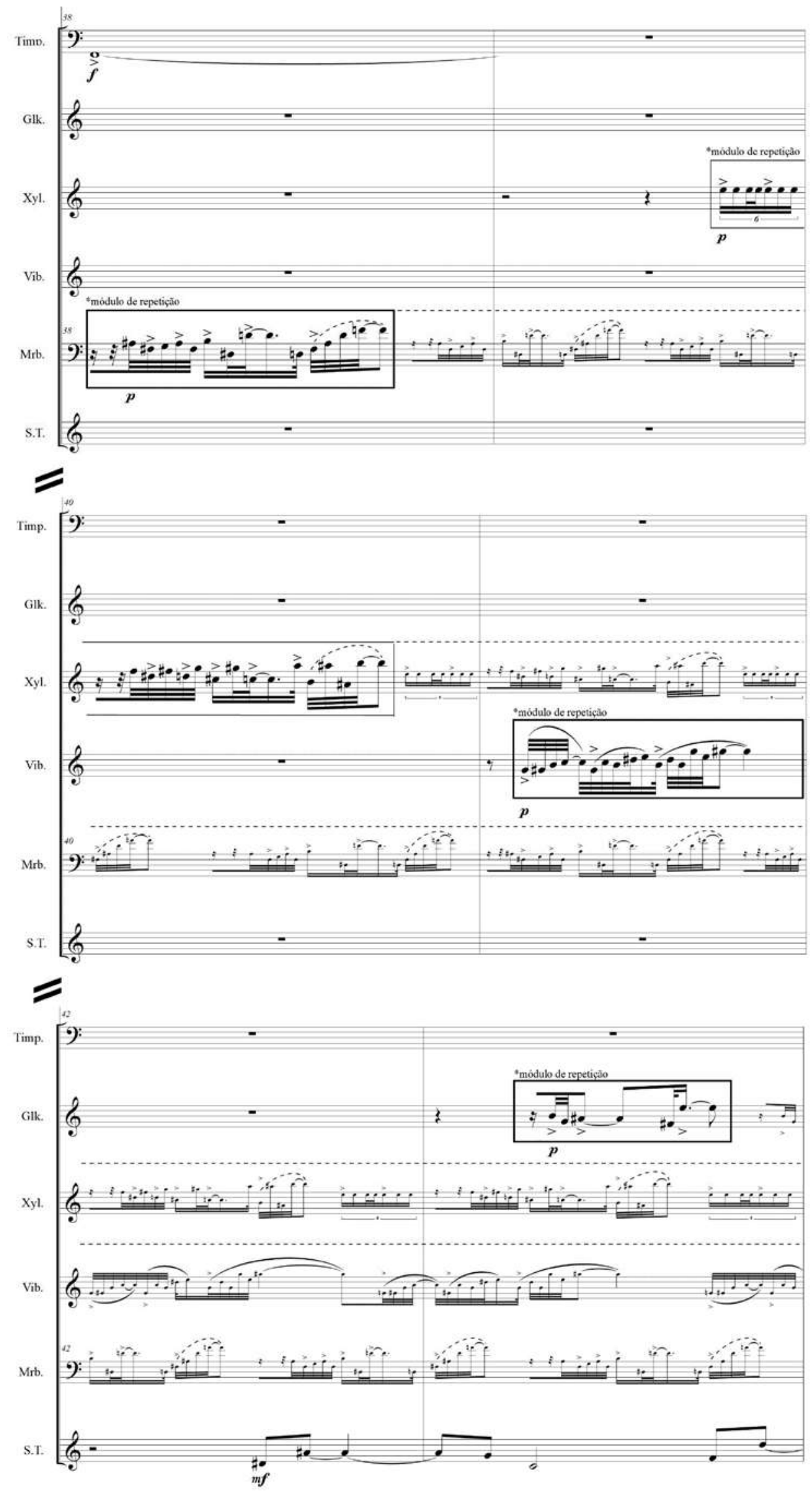

Exemplo 11: Textura modular, em Dakunohrum (c. 38-43) 
Nesta construção narrativa que simbolicamente representa eventos específicos de meu percurso etnográfico, a consciência da necessidade de uma experiência orgânica e subjetiva como estratégia metodológica de pesquisa aparece musicalizada na seção mais longa da obra (c. 77-150), onde uma confabulação contrapontística de estruturas rítmicas cíclicas, intensas, dançantes e de fluxo contínuo traz à tona uma atmosfera ritualesca, pautada, inclusive, numa adaptação, poeticamente licenciada, da energia idiossincrática da música de candomblé e na utilização protagonizada de seus instrumentos típicos (atabaque e agogô). Um trecho pontual deste importante momento da obra está ilustrado no exemplo 12.

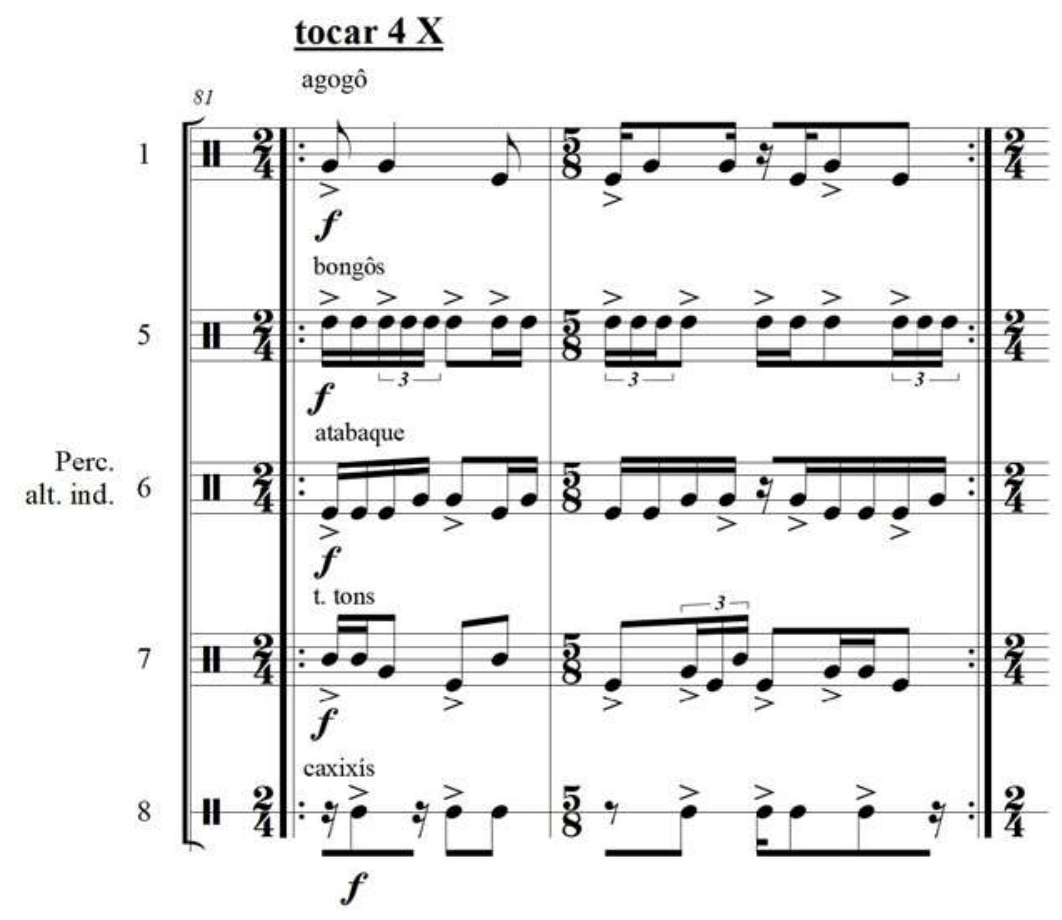

Exemplo 12: Atmosfera ritualesca, em Dakunohrum

A peça tem o seu desfecho demarcado por uma seção que rememora os materiais principais da obra, todos atrelados, mais uma vez, a uma textura rala, contida e de tendência não linear, que é enfaticamente interrompida por espécies de explosões abruptas que expõem curtíssimos gestos rítmicos de muita intensidade. Todo este trecho representa os momentos finais de algumas experiências etnográficas, cuja ação reflexiva, de interpretação e racionalização da própria experiência, toma conta da atividade mental do "eu pesquisador". Um detalhe específico deste trecho final diz respeito ao último compasso da obra, onde é articulada uma figuração rítmica no agogô e no atabaque comum à finalização de cantigas típicas do contexto de candomblé, cuja função é revelar a fonte da experiência etnográfica que inspira a concepção geral da obra. 


\subsubsection{Situação analítica I: sublimação rítmica como princípio de agenciamento de contrastes}

Com bastante frequência, sobretudo no primeiro terço da obra, o conceito de sublimação rítmica atua como um princípio agenciador da alternância contínua de seções que se diferenciam pelos seus caráteres e disposições texturais: uma de tendência não linear, onde a percepção de metas e direcionalidade composicionais, bem como as sensações métricas e até de pulso, ficam relativamente diluídas; e outra cuja sensação do fluxo temporal é mais precisamente medida, onde existe uma direcionalidade evidente.

Vale destacar que as texturas de tendência não linear, no caso desta peça, são construídas a partir de duas maneiras: 1) andamentos lentos e figurações rítmicas longas e interpenetráveis, que dificultam a percepção objetiva de agrupamentos e, portanto, da relação entre valores acentuados e não acentuados, e, consequentemente, de regularidade em termos de pulso; e 2) estruturas modulares que acomodam materiais musicais independentes que se interpenetram num complexo que inspira desordem (vide o exemplo 11). Já as texturas de linearidade são formadas a partir do extremo oposto: andamentos rápidos, valorizados por figurações rítmicas curtas que potencializam a percepção de agrupamentos, a intuição de pulsos regulares e uma sensação métrica bem definida, num fluxo temporal direcional.

A mudança desses dois tipos de texturas é sempre catalisada por um instrumento (quase sempre o tímpano), que realiza uma ação musical de ativação de mudança, atuando como o rum, nos casos pouco frequentes de contrastes de temporalidades na música de candomblé, vistos em ritmos com o adarrum.

No exemplo 13a é possível perceber o desfecho de uma textura não linear (c. 2124), que condiz com o surgimento do material musical pivô da sublimação rítmica (frase de tímpano aliada a um ataque de queixada, marcadas em círculo amarelo). No exemplo 13b, visualiza-se um tipo de textura completamente diferente, linear, direcional e alimentada por uma espécie de regressão métrica, onde a sensação temporal está "sublimada" em relação ao que ocorria em compassos anteriores. Este mesmo processo compositivo reaparece de maneiras distintas na obra, em termos de densidade, dinâmica e timbre. Na verdade, os contrastes principais da peça são motivados por esse princípio, o que resulta na utilização da sublimação rítmica como um mecanismo estratégico de articulação formal. 


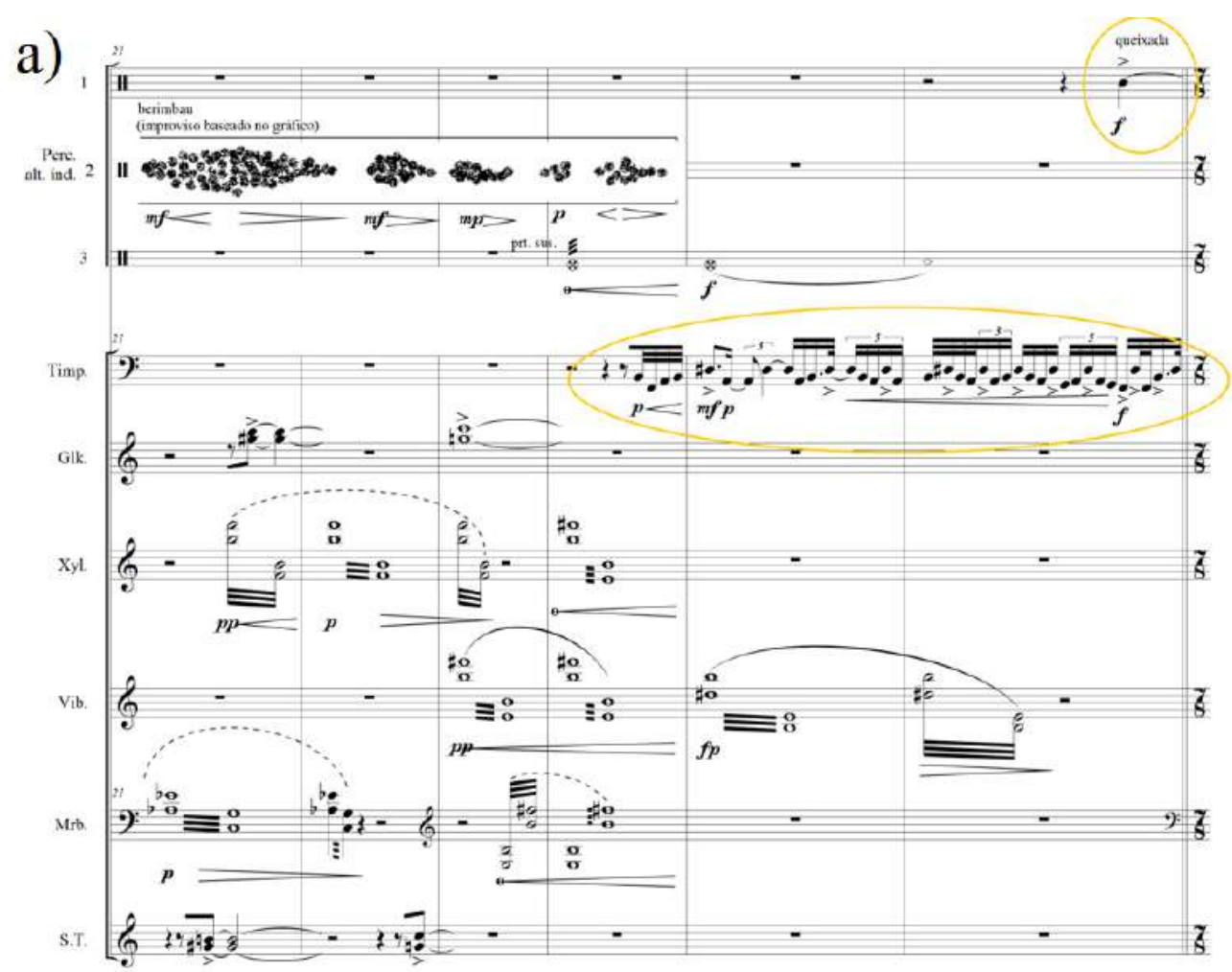

Exemplo 13a: Sublimação rítmica como princípio de agenciamento de seções contrastantes, em Dakunohrum (de tendência não linear, c. 21-26)

b)

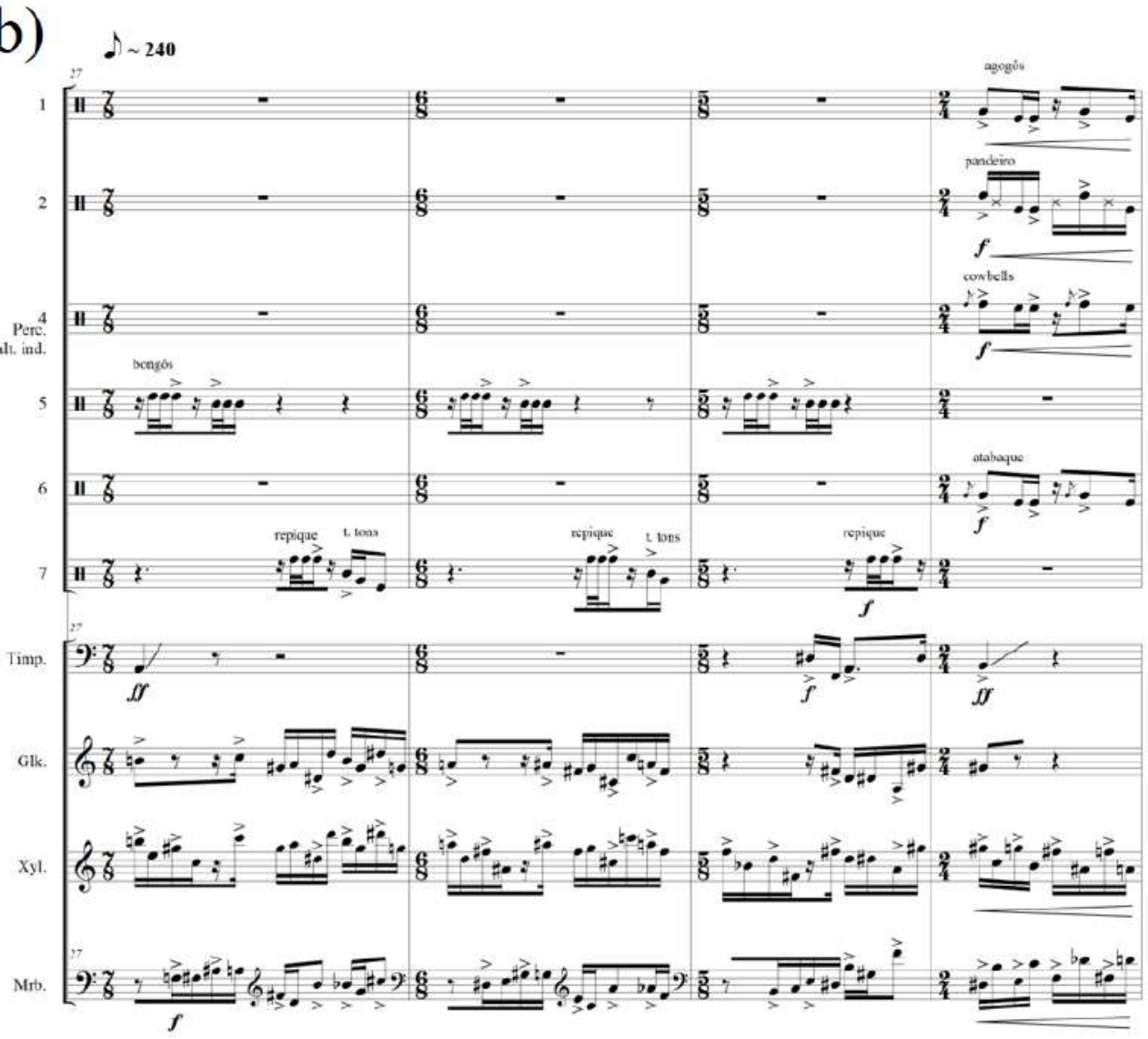

Exemplo 13b: Sublimação rítmica como princípio de agenciamento de seções contrastantes, em Dakunohrum (de tendência linear e direcional, c. 27-30) 


\subsubsection{Situação analítica II: a ressignificação rítmica como princí- pio de variação de material}

A ressignificação rítmica preenche quase todas as ações compositivas da segunda grande seção de Dakunohrum. Ela é implementada a partir de uma estratégia simples, mas que causa um interessante efeito auditivo: um material rítmico assemelhado a uma clave de candomblé (um espécie de ijexá transformado ${ }^{23}$ - exemplo 14) é executado pelo agogô por um longo período e submetido a ambientes rítmicos diversificados que promovem diferentes feições à sua identidade e fazem com que ele seja ouvido e interpretado de maneira diferente. Neste sentido, o conceito de ressignificação rítmica é utilizado com a finalidade de promover variações múltiplas de um mesmo material musical, sem que a sua essência seja alterada - os contextos sonoros nos quais ele aparece submetido é que são alterados.

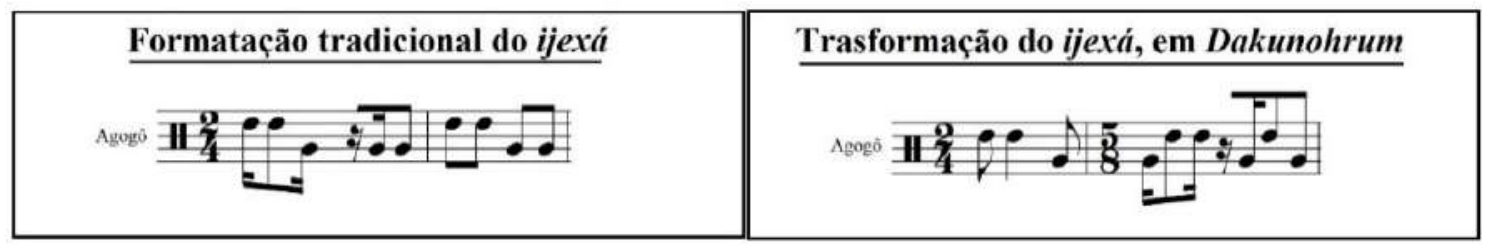

Exemplo 14: Transformação do ijexá, em Dakunohrum

Os exemplos 15a, 15b e 15c ilustram três feições distintas do material rítmico apresentado pelo agogô, levando em consideração as diferentes maneiras que ele é intuído, a partir do contexto musical que ele integra. Em 15a, observa-se uma textura homofônica, na qual o toque de agogô, como elemento de acompanhamento, acomoda um solo de sinos tubulares que desvirtua a sua ordem métrica, propondo ao mesmo uma maneira diferente e ressignificada de localização temporal - os sinos tubulares desenvolvem uma melodia temporalmente regular, de fluxo binário (apoiada pela ordem precisa de entrada dos teclados: de duas em duas semínimas), que força uma interpretação alternativa à expectativa natural associada à sua organização agrupacional (essencialmente irregular). Em 15b, vê-se uma textura polirrítmica na qual o padrão irregular de agogô se contrapõe a outros padrões regulares e de tendência ternária, que também impõem uma lógica diferente de percepção temporal. E, em 15c, tem-se outra textura polirrítmica, sobre a qual o toque cíclico e irregular de agogô se contrapõe a outro padrão também cíclico e de estrutura irregular (implementado pala marimba e pelo xilofone), embora longitudinalmente maior - essa diferença de tamanho entre os dois materiais, tendo em vista as suas disposições espaciais, resulta numa engrenagem de movimentação contínua dos pontos de acentuações relativos aos seus modos de interação, permitida pelo cruzamento de seus ciclos distintos de periodização, ${ }^{24}$ implicando uma variante intuitiva do ritmo expresso pelo agogô.

\footnotetext{
23 Nesta transformação, os dois agrupamentos correspondentes ao que poderíamos considerar como os dois compassos do ijexá aparecem trocados de ordem, o primeiro deles com um ataque suprimido e o segundo com um ataque adicionado, numa disposição métrica variada.

24 Desta engrenagem surge uma expectativa de que em dado momento os pontos de iniciação de cada ciclo se encontrarão. Até que isto aconteça, eles são continuamente recombinados, de modo que um interfere em como o outro é percebido em cada recapitulação.
} 

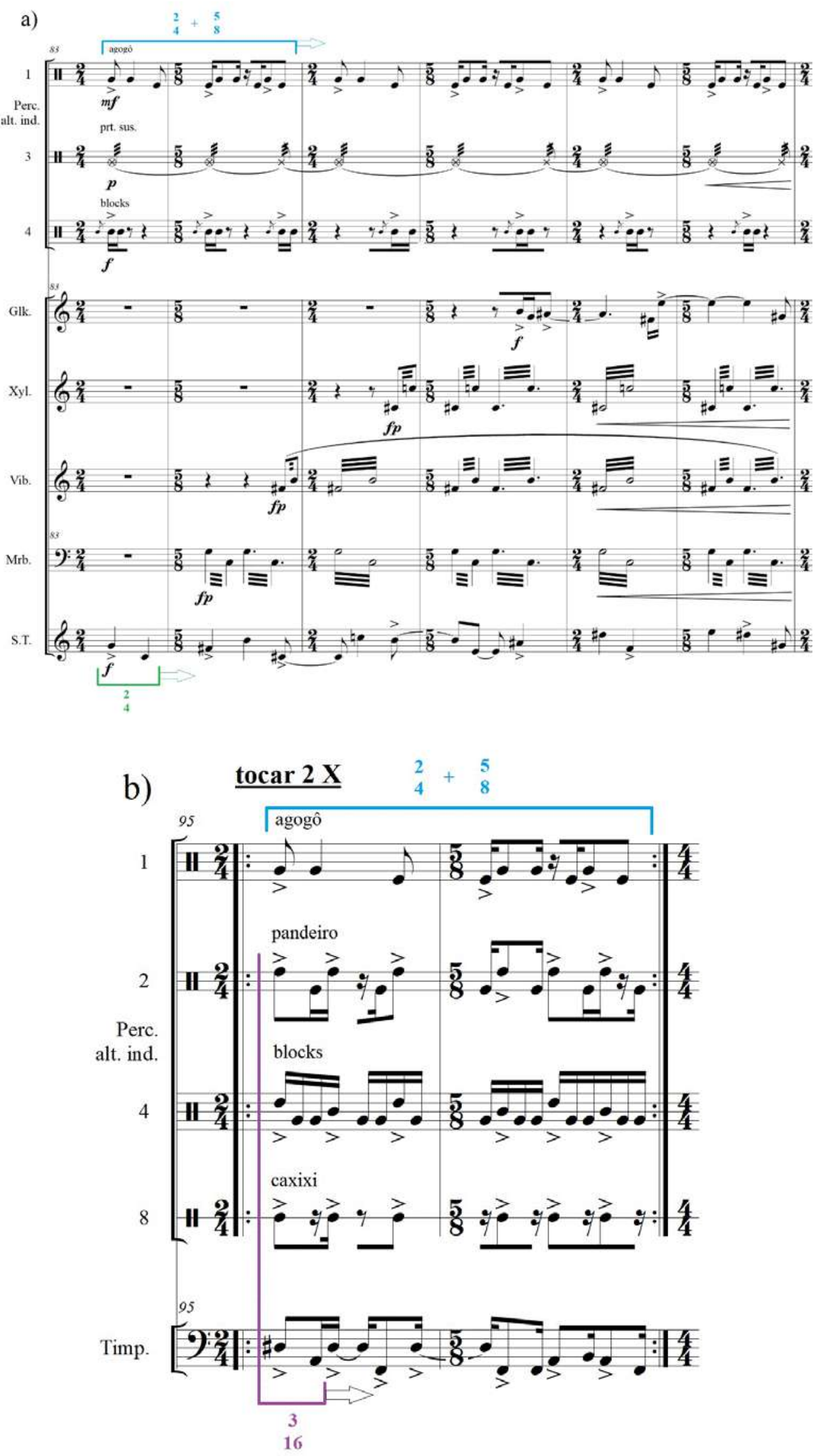


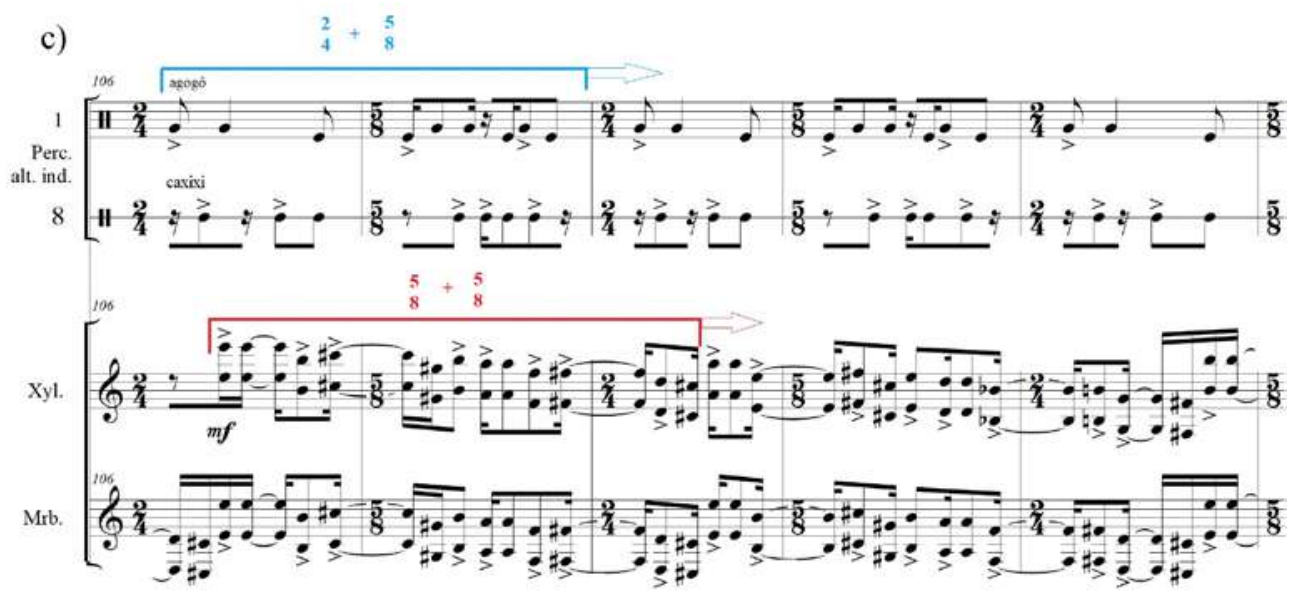

Exemplo 15: Ressignificação rítmica, em Dakunohrum

\subsubsection{Situação analítica III: a sublimação rítmica como princípio de interrupção momentânea de uma ordem musical previamente constituída}

Na última seção da obra é possível perceber uma outra abordagem da sublimação rítmica. Nesta, o princípio conceitual é usado como processo compositivo para promover interrupções momentâneas de uma ordem musical previamente estabelecida. Lembremos: na seção final de Dakunohrum há uma espécie de rememoração dos materiais principais da obra, todos atrelados a uma textura rala, contida e de tendência não linear apresentada em seus compassos iniciais. Essa ordem é remontada progressivamente, mas não adquire consistência, pois, em intervalos temporais imprevisíveis, a continuidade da atmosfera sonora criada é ameaçada por pequenos eventos rítmicos bastante contrastantes. Estes são sempre desencadeados por uma motivação musical, uma intervenção rítmica, seja ela executada pelo timpanista ou pelo percussionista 8 , que toca um set baseado na montagem de uma bateria (repique, caixa clara, 3 t. tons e prato). Tais instrumentos, de uma maneira alternativa à apresentada na "situação analítica I", assumem a função simbólica do rum. O exemplo 16 ilustra um desses momentos - as intervenções rítmicas que desencadeiam os eventos contrastantes estão marcadas em círculos vermelhos. 


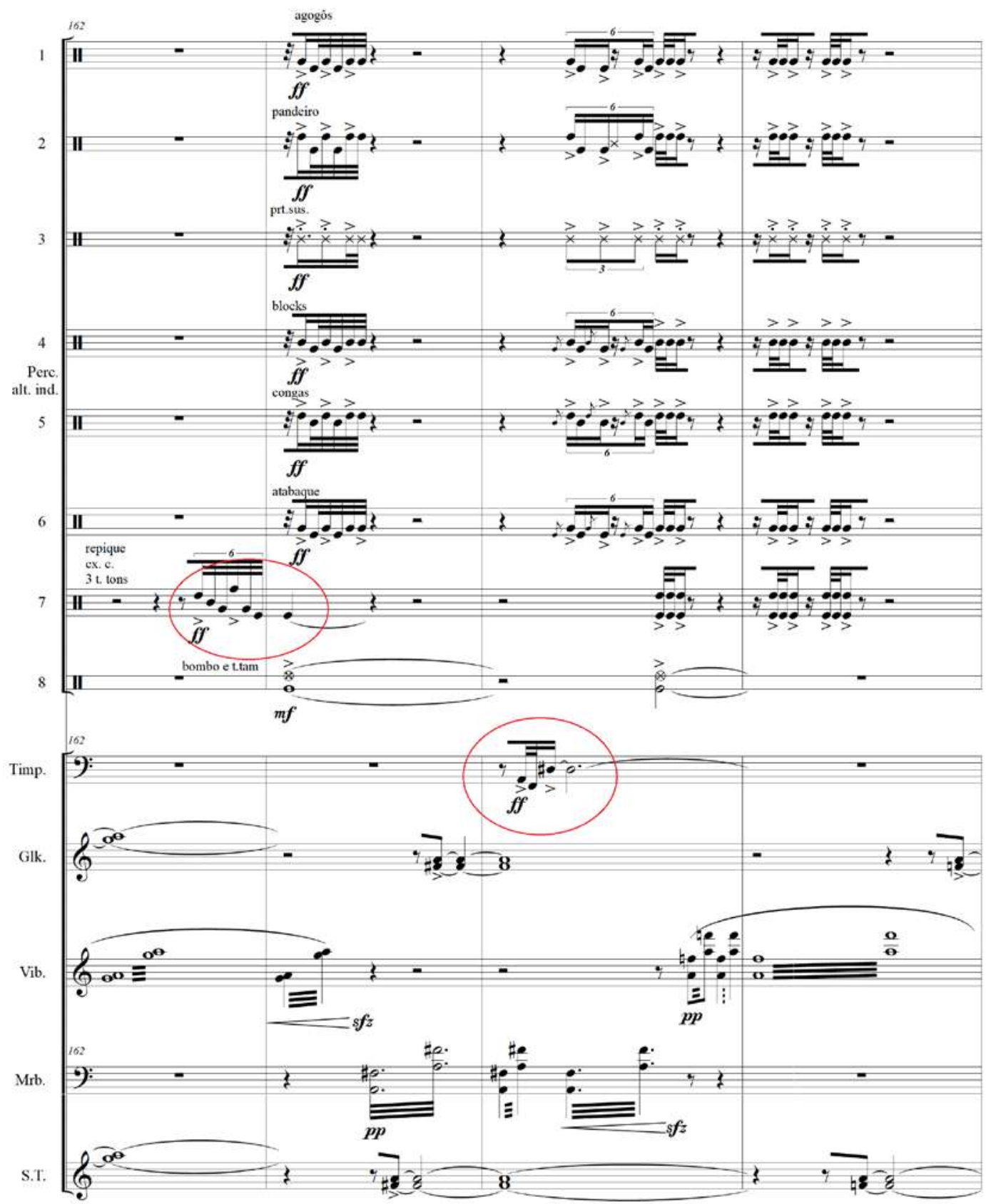

Exemplo 16: Sublimação rítmica como princípio de quebra de fluxo musical, em Dakunohrum

\subsubsection{Como Brisa na Costa de Santos}

A concepção geral desta obra nasceu de circunstâncias bem específicas: recebi um convite para escrever uma peça para flauta, clarinete, bouzouki ${ }^{25}$ e piano, que deveria homenagear algum aspecto da vida ou obra do compositor santista Gilberto Mendes, falecido no primeiro dia daquele mesmo ano (2016). As exigências da enco- 
menda foram fundamentais para o planejamento composicional. A minha estratégia foi homenagear uma das obras mais conhecidas de Mendes: Vento Noroeste. Neste sentido, pensei numa trama narrativa que pudesse me ajudar na elaboração de um discurso musical: o vento noroeste, metaforicamente assumido como a própria obra do referido compositor, chegaria como brisa na baía de Todos os Santos, e nela adquiriria traços de baianidade - isso justifica o título Como Brisa nas Costas de Santos. Sendo assim, o vento noroeste, como brisa, apareceria na composição metaforizado em seis recortes pontuais da peça de Mendes, a serem utilizados como citações literais, que ganhariam outras implicações musicais. O número seis não surge de uma arbitrariedade: a menção à baía de Todos os Santos propõe alguma associação à cultura do candomblé, e nesta há uma entidade de culto (orixá) que, por razões religiosas, ocupa uma posição de destaque: Oxalá, cujo dia da semana simbólico é sexta-feira.

O exemplo 18 (c. 43-50) ilustra parte desta trama. Neste, o segundo recorte de Vento Noroeste (exemplo 17) aparece exposto no piano, já desenvolvido (após ter sido citado, com fidedignidade, em compassos anteriores), e pouco a pouco vai sendo influenciado por um gesto musical marcado pela interatividade da flauta, clarinete e bouzouki, gesto esse que desemboca (c. 49 e 50), justamente, numa versão melódico-harmônica do ritmo de candomblé vassi, rotacionado e variado (exemplo 19).

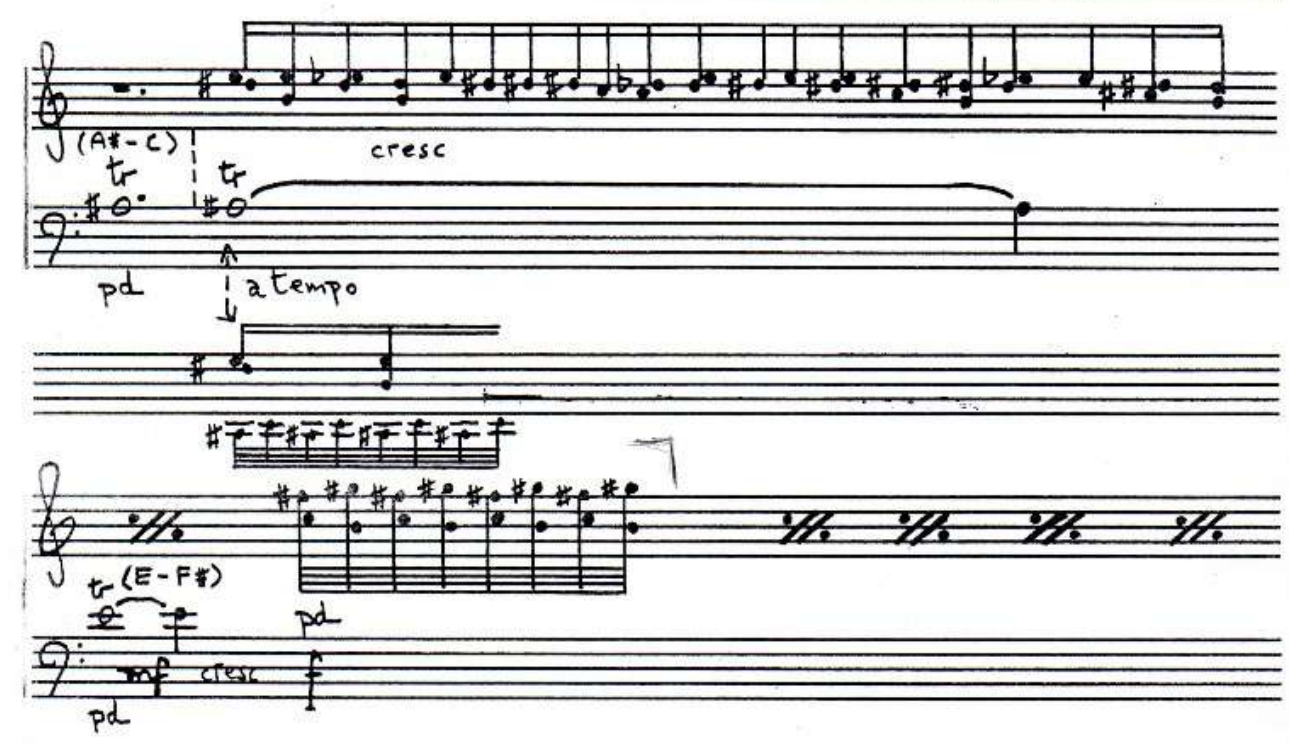

Exemplo 17: Recorte citado de Vento Noroeste (partitura original) 

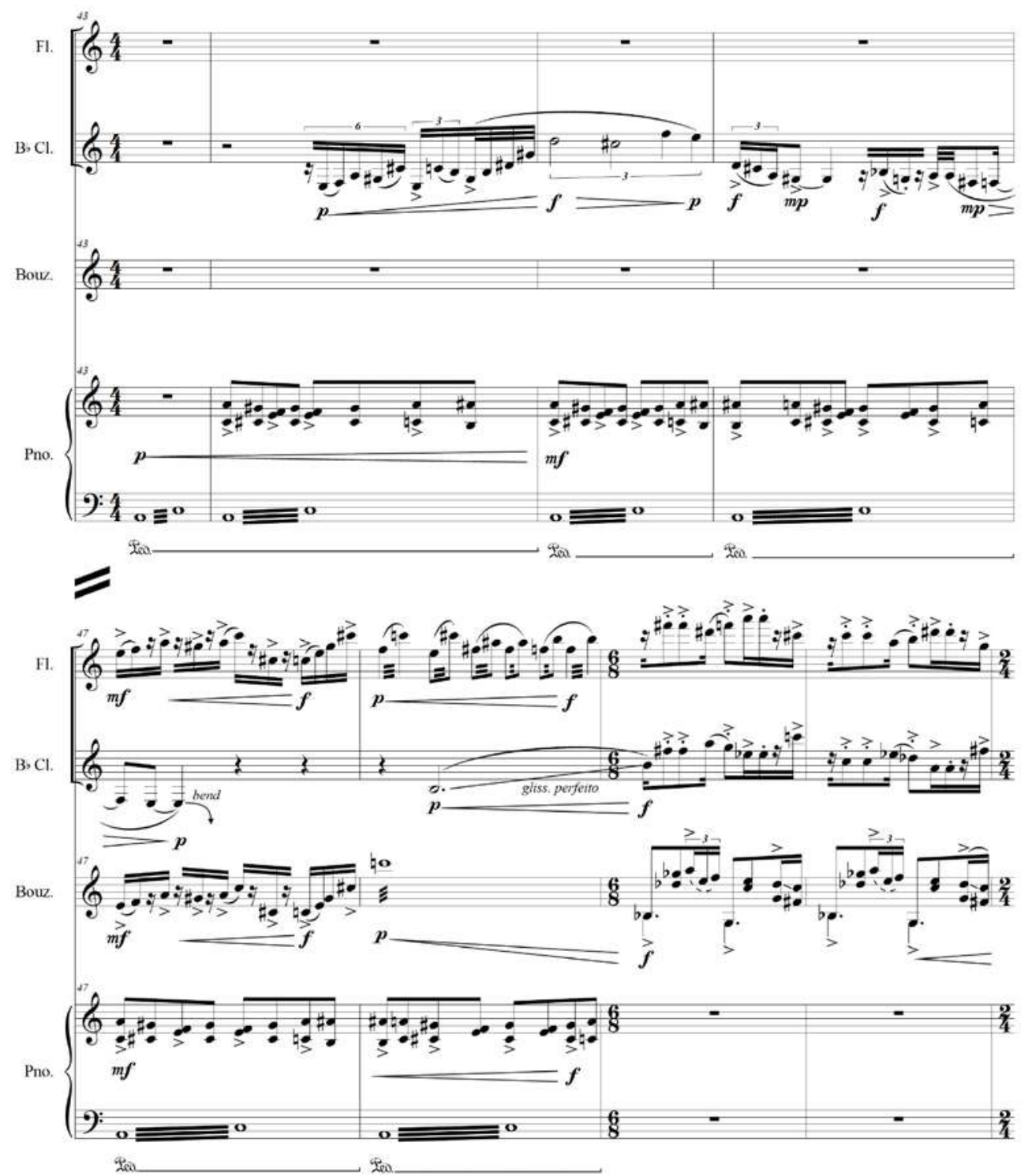

Exemplo 18: Recorte citado de Vento Noroeste, em Como Brisa nas Costas de Santos

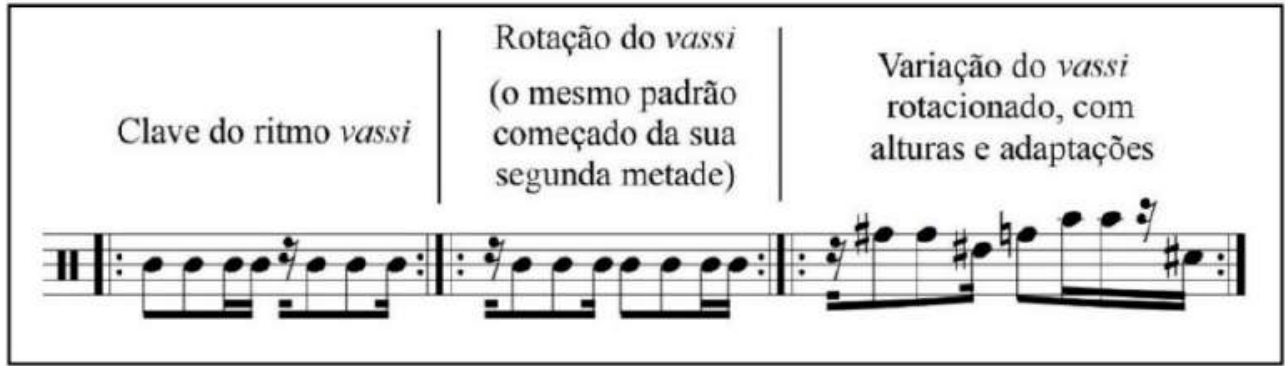

Exemplo 19: Rotação do vassi, em Como Brisa nas Costas de Santos

\subsubsection{Situação analítica I: a sintonização rítmica como princípio de transformação textural}

Em momentos estratégicos de Como Brisa nas Costas de Santos, o conceito de sintonização rítmica foi utilizado enquanto metáfora para a ideia de "juntos $\mathrm{X}$ separa- 
dos - em sintonia X fora de sintonia" - , tal como é possível perceber, com frequência, na música de candomblé, onde a atuação do rum determina situações de polirritmia, quando ele se descola do grupo construindo linhas rítmicas independentes, ou de homorritmia, quando ele atua como um potencializador dos pontos de acento e agrupamentos específicos de uma determinada clave, executada no gã e atabaques rumpi e lé. Com esta premissa, gestos musicais foram criados a partir de texturas que acomodam linhas completamente independentes entre os instrumentos, impondo sensações polifônicas e polirrítmicas, que são contrapostas a texturas onde as linhas instrumentais se desenvolvem conjuntamente, isto é, entram em sintonia. Isto pode ser visualizado no exemplo 20: os compassos 35 e 36 ilustram o desfecho de uma textura implementada a partir de linhas instrumentais individuais e não necessariamente complementares, que é contraposta a uma outra textura onde todos os instrumentos atuam conjuntamente (c. 38-42). O compasso 37 (marcado em caixa vermelha) funciona como uma espécie de eixo que une os dois gestos distintos, e, neste sentido, funciona como um ativador da sintonização.

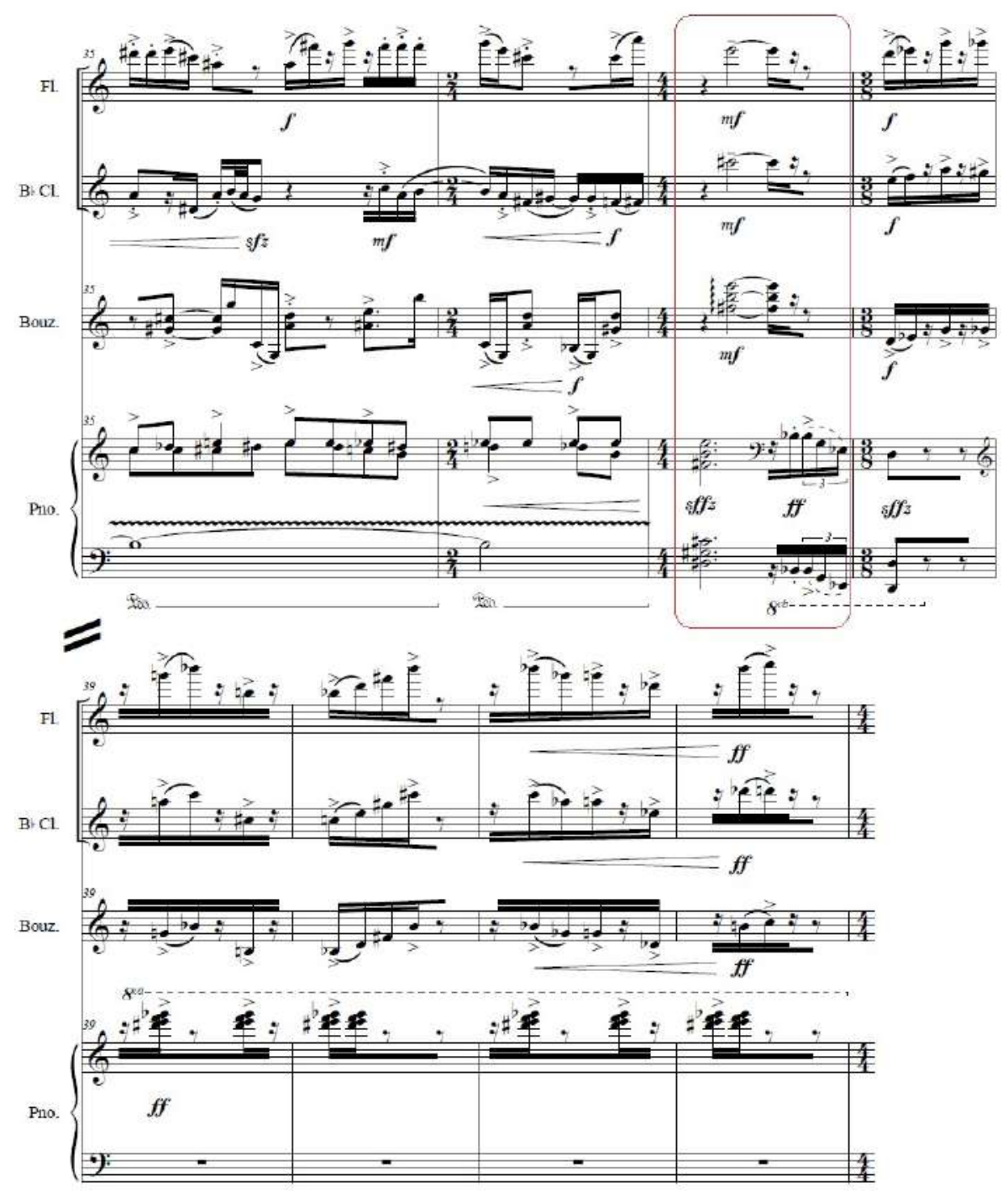

Exemplo 20: Sintonização rítmica como princípio de transformação textural, em Como Brisa nas Costas de Santos 


\subsubsection{Situação analítica II: a dissociação rítmica como processo de desenvolvimento rítmico e gestual}
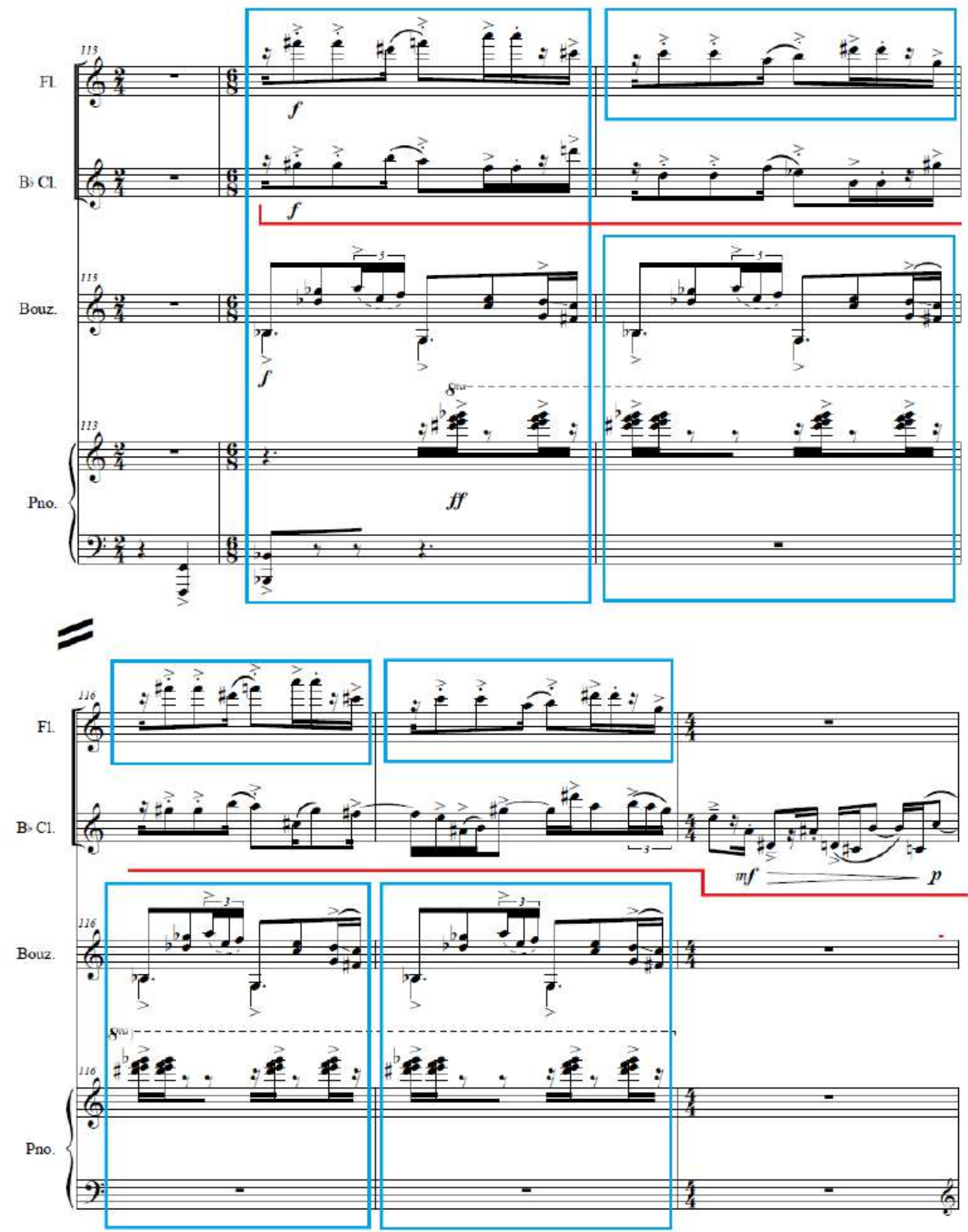

Exemplo 21: A dissociação rítmica como processo de desenvolvimento rítmico e gestual, em Como Brisa nas Costas de Santos

Como recurso compositivo favorável ao desenvolvimento rítmico e gestual de um contexto musical fundamentado na retroalimentação de materiais numa perspectiva cíclica, o processo de dissociação rítmica foi implementado nesta obra de maneira idêntica ao que é vivenciado naturalmente na música de candomblé, tal como foi descrito a partir das transcrições. Com este ímpeto, um composto rítmico formado a partir da sobreposição de linhas instrumentais individuais (marcado em caixas azuis), ilustrado no 
exemplo 21 (c. 113-118), é reiterado ciclicamente durante quatro compassos, enquanto uma parte deste composto, correspondente ao clarinete (marcada em linha vermelha), é descolada progressivamente do "todo", e, assim, dissociada, criando um caminho individual e paralelo, assumindo pouco a pouco uma função solista. Esta ideia alicerça o pensamento composicional da seção que inicia o percurso de desfecho da peça (c. 110-130), com variações importantes em termos de densidade, timbre e de elemento a ser dissociado - por exemplo: em compassos seguintes ao trecho ilustrado, o mesmo composto rítmico é alvo do processo de dissociação, com a diferença significativa de que a parte correspondente ao bouzouki é desmembrada.

\subsubsection{Situação analítica III: a suspensão rítmica como recurso para a promoção de tensão}

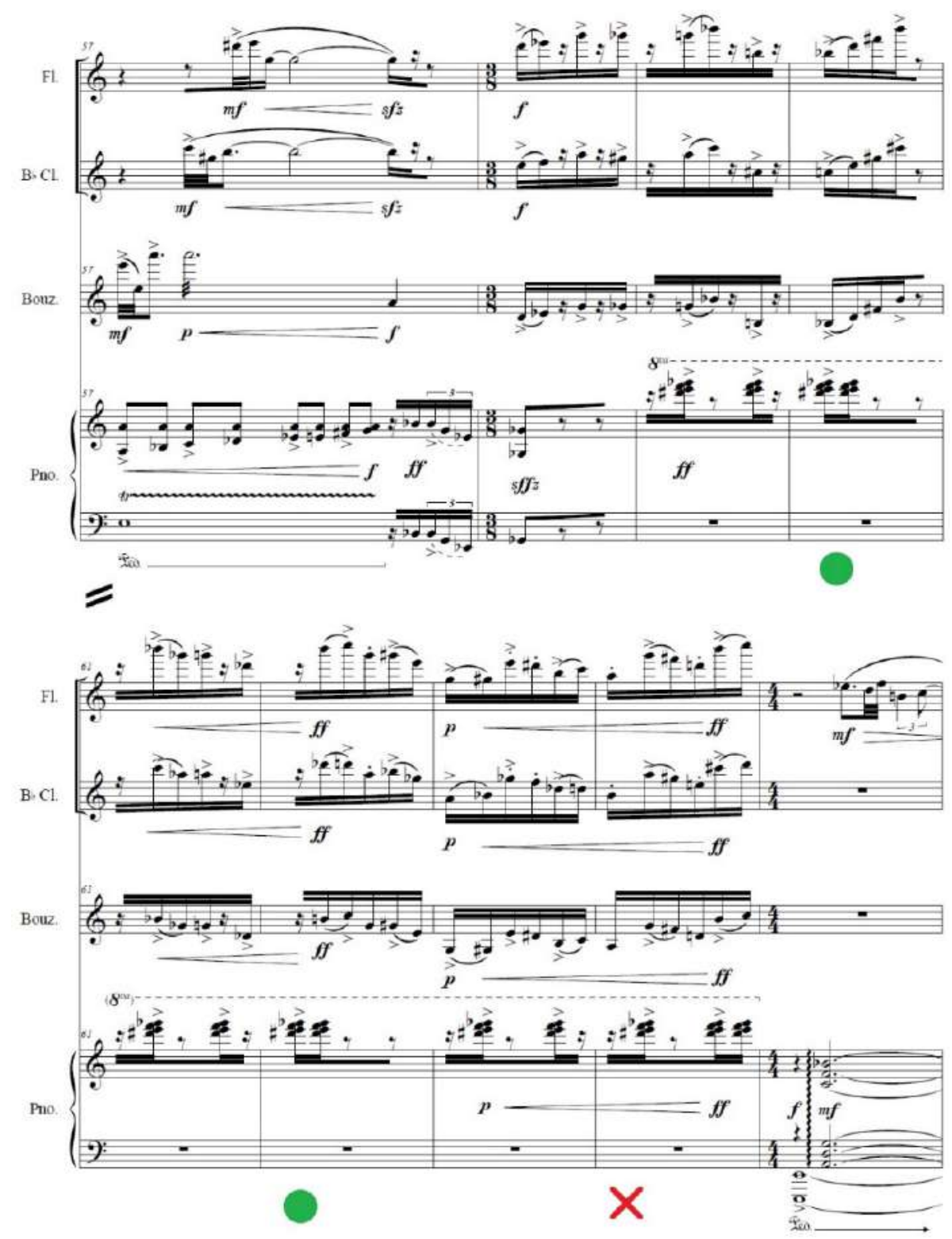

Exemplo 22: A suspensão rítmica como recurso para a promoção de tensão, em Como Brisa nas Costas de Santos 
Gestos similares àquele onde o corpo instrumental aparece sintonizado, no exemplo 20, são frequentemente reiterados na obra, como uma espécie de refrão, com a função objetiva de promover uma homogeneização do discurso musical, outrora difuso e pulverizado. Há um momento específico em que ele antecede uma importante mudança de seção, mais ou menos no ponto médio da obra (exemplo 22), assumindo, portanto, um papel cadencial. Neste, a ideia de suspensão rítmica aparece como um recurso para a promoção de tensão. Observa-se que o gesto é apoiado por ataques de clusters ao piano, que marcam com precisão a gravidade métrica (sinalizada pelos pontos verdes). No final do gesto, este apoio é suprimido (sinalizado pelo " $X$ " em vermelho), causando uma sensação de suspensão e criando uma tensão importante no seu desfecho, que é "resolvida" na seção que o segue.

\subsubsection{Impulsos}

Esta peça foi escrita para a ocasião do concerto de estreia da temporada Em Refluxo, do Camará Ensemble, tendo como base a formação de um septeto (flauta, clarinete, banjo, violão, violino, violoncelo e percussão múltipla). Diferentemente do que vimos até então, o processo de feitura desta música não responde a nenhuma estrutura narrativa previamente elaborada - as tramas projetadas para esta aventura são pura e simplesmente sonoras, muito embora o estabelecimento de limites que faz brotar o seu ímpeto criativo se relacione com o papel de imponência que a clave exerce na música de candomblé e em seus resultados sonoros.

Grosso modo, Impulsos promove uma problematização a respeito dos padrões de gã mais comuns do candomblé, quando faz deles materiais germinadores de um discurso composicional ligado ao imaginário da música de concerto contemporânea, expondo as suas genuínas potencialidades sonoras e submetendo-os também a situações temporais, harmônicas e gestuais dificilmente imaginadas no contexto natural da referida cultura. Nesta direção, a concepção geral da peça é identificada num perfil global que tem o início marcado por manifestações demasiadamente sutis dessas claves, onde as mesmas se apresentam de maneira absolutamente velada, e, gradualmente, vão se impondo no fluxo sonoro, fazendo valer as suas identidades, em direção a uma seção de clímax formal imponente e cheia de energia, onde elas conversam entre si e tomam conta de toda superfície musical.

Para os momentos que projetei a manifestação velada das claves, trecho que corresponde à primeira grande seção da obra (até o c. 40), procurei representá-las pelo que considero como o elemento estrutural mais básico de todo time-line pattern frequentemente apreciado no candomblé: o agrupamento Tróqueo $(-\mathrm{U})^{26}$ - o elemento que,

\footnotetext{
26 Cooper e Meyer (1960) chamam de padrões de agrupamentos rítmicos, ou, simplesmente, de ritmo, o que pode ser definido mais precisamente como "a forma com que uma ou mais batidas não acentuadas são agrupadas em relação a uma acentuada" (1960, p. 6). Para os autores, existem cinco tipos que, no âmbito da teoria, são associados aos padrões gregos de prosódia, os Pés-Gregos: 1) lambo, fraco-forte (U -); 2) Anapesto, fraco-fraco-forte (U U -); 3) Tróqueo, forte-fraco (- U); 4) Dáctilo, forte-fraco-fraco (- U U); e 5) Anfíbraco, fraco-forte-fraco (U - U). Nesta bibliografia, e em muitas outras posteriores que tratam da teoria do ritmo, buscando inclusive uma fundamentação cognitiva (CONE, 1968; BERRY, 1976; EPSTEIN, 1979, 1985; LERDAHL; JACKENDOFF, 1983; KRAMER, 1988; HASTY, 1997, entre outros), há uma esperança de que a combinação desses agrupamentos básicos deem conta da observação analítica de grande parte das estruturas rítmicas vivenciadas pelo mundo, em suas diferentes culturas.
} 
por exemplo, garante a assimetria dos toques irregulares, mesmo quando a sensação de pulso se manifesta de maneira composta, tal como ocorre no já mencionado vassi. O exemplo 23 demonstra a presença do agrupamento tróqueo em diferentes claves, impondo a sua implicação binária (ou quaternária, a depender do nível de pulsos observado). É importante destacar como ele articula a assimetria do vassi, formando as partes binárias e quaternárias dentro da estrutura " $4+3+2+3$ (ou $7+5$ )".

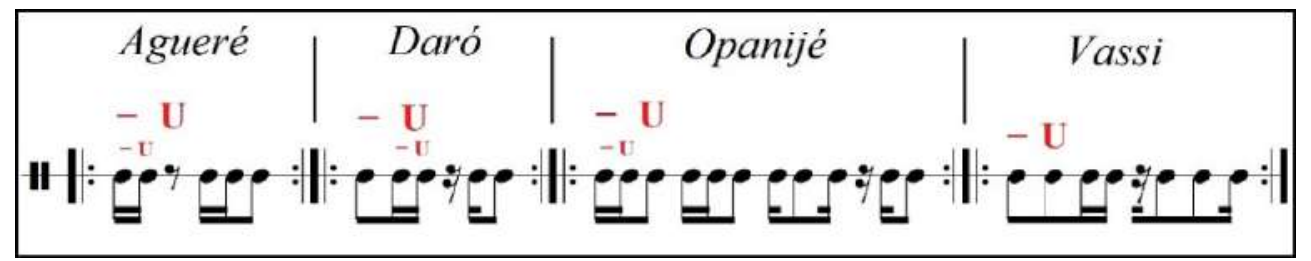

Exemplo 23: O agrupamento tróqueo (- U) como elemento rítmico básico estrutural de variadas claves de candomblé

Esta pequena estrutura, como representação de uma variedade de claves, fundamenta o elemento motívico principal da primeira seção de Impulsos - de onde toda a energia da música provém (exemplo 24a) e para onde toda a energia da música retorna (exemplo 24b). O final da obra é marcado pela execução do mesmo.

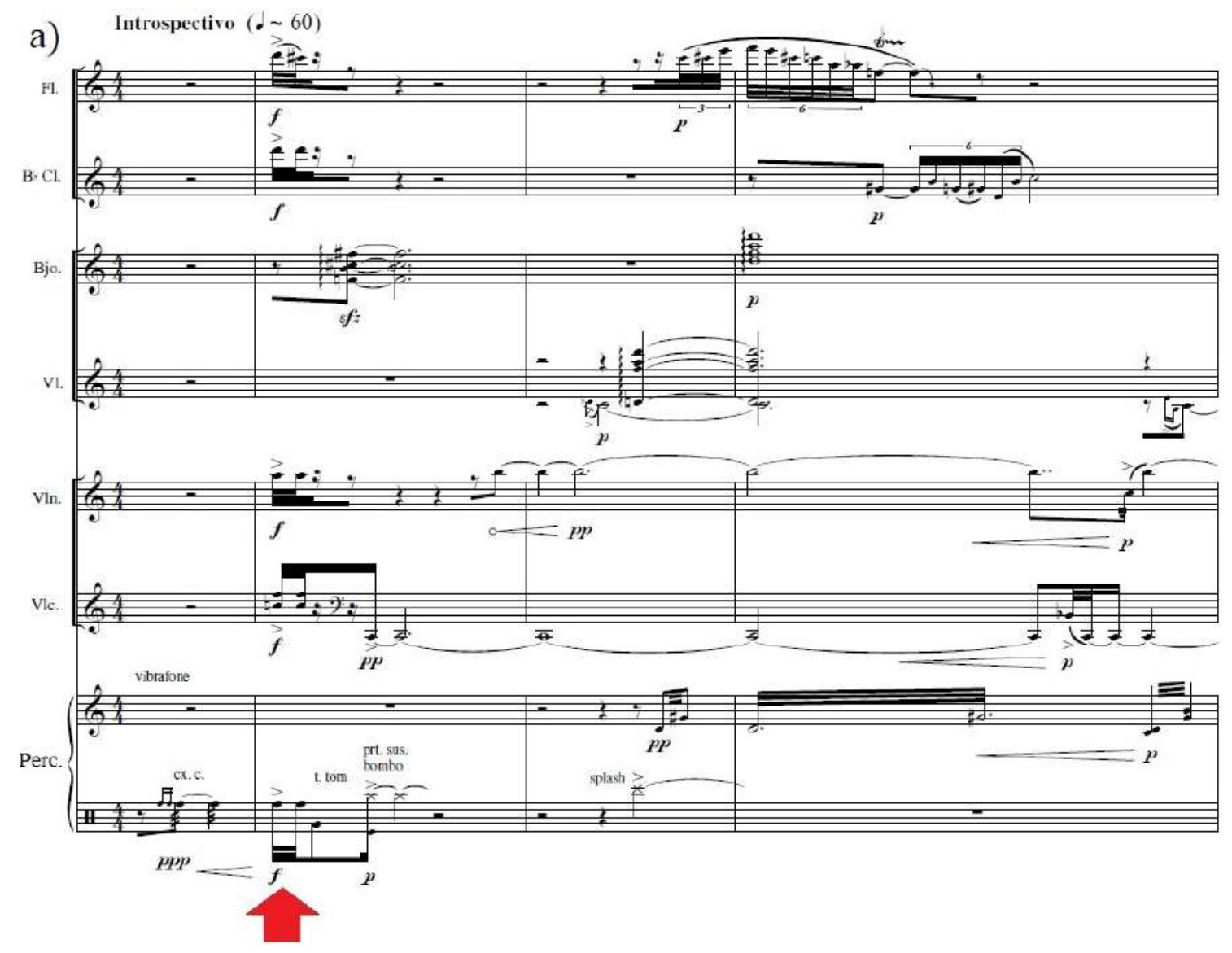




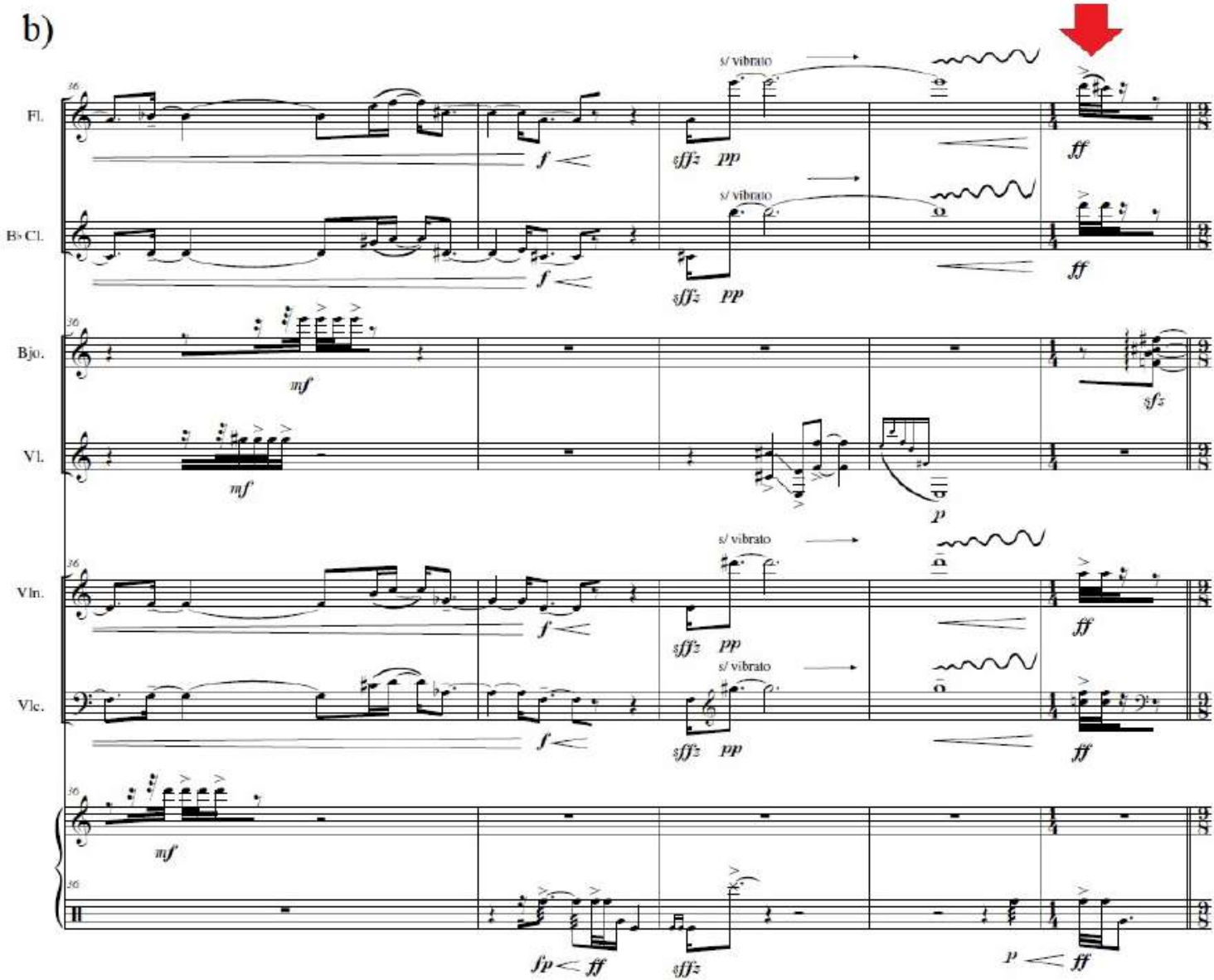

Exemplo 24: O agrupamento tróqueo como elemento básico das relações sonoras da primeira seção de Impulsos

A primeira seção de Impulsos é seguida de uma seção intermediária na qual várias claves de candomblé são citadas na íntegra pelo percussionista, ao passear pelo colorido timbrístico de seu set de instrumentos, entretanto com baixo potencial de reconhecimento, pelo fato de que elas são tocadas de uma maneira difusa, uma após outra, com um intervalo temporal impreciso, sem a engrenagem cíclica ligada à sua idiossincrasia, e como plano de fundo para uma textura que tem lá as suas complicações, com picos de uma "linearidade multidirecionada" (KRAMER, 1988). O primeiro toque citado é o agueré, que é seguido consecutivamente pelos savalu, daró, batá, vassi e jicá. ${ }^{27}$ Os mesmos voltam a ser tocados na ordem contrária até a repetição do agueré (c. 41-70). Esta seção, de caráter transitório, antecipa a parte mais importante da obra, na qual alguns desses toques, todos com as suas respectivas linhas típicas de rum, assumem o protagonismo do discurso musical de uma maneira bem peculiar.

\subsubsection{Situação analítica I: processo modulante de claves sucessivas}

No âmbito da seção de clímax formal de Impulsos (c. 82-118), quatro claves específicas de candomblé são abordadas: agueré, daró, opanijé e batá. Cada uma delas 
demarcando seus impulsos rítmicos próprios e idiossincráticos, quase que simultaneamente, mas sem se misturarem ou perderem a organicidade. Tais toques são explorados em suas diferenças, quando contrapostos horizontalmente, implementando um fluxo compositivo constantemente interrompido, numa perspectiva temporal multidirecional. Em larga escala, através de uma espécie de processo modulante, o agueré é progressivamente tomado pelo daró, que cede espaço para o opanijé, que, por sua vez, é superado pelo batá - algo improvável no contexto tradicional do rito de candomblé. Assim, os trechos de agueré vão ficando cada vez menores, enquanto os de daró vão crescendo; os trechos de daró vão ficando cada vez menores, enquanto os de opanijé vão crescendo; e, por conseguinte, os trechos de opanijé vão perdendo espaço, enquanto os de batá ganham força. O exemplo 25 (c. 90-101) demonstra parte disso: o agueré amalgamado no fraseado do banjo (c. 90, 91 e 94) é progressivamente invadido pelo daró, impresso no violino (c. 93 e 94; 96-99), que, paulatinamente, passa a ser interrompido pelo opanijé expresso nas articulações rítmicas da melodia do clarinete (c. 100 e 101).

Outro ponto a ser esclarecido brevemente são as maneiras pelas quais cada padrão rítmico ganha corpo e se desenvolve no tecido musical desta seção. Em geral, através de uma espécie de simulação do comportamento musical relativo ao quarteto instrumental da música de candomblé: há sempre elementos que aparecem de modo progressivo representando cada um dos quatro instrumentos. Observa-se que, enquanto o banjo assume o papel dos atabaques rumpi e lé na montagem do agueré, a percussão personifica o gã, e o violão, o rum (c. 90 e 91); enquanto o violino assume o papel de gã na montagem do daró, a percussão personifica os atabaques rumpi e lé, e o violoncelo, o rum (c. 96-99. Esta traquitana rítmica, que naturalmente inspira parte dos processos rítmicos discutidos anteriormente, visto a simulação poeticamente licenciada do grupo musical de candomblé em um contexto de instrumentos ocidentais, é revestida de uma abordagem de alturas baseada em estruturas escalares simétricas, em especial as aumentadas e octatônicas, e em níveis graduais de densidade textural e impacto gestual. 

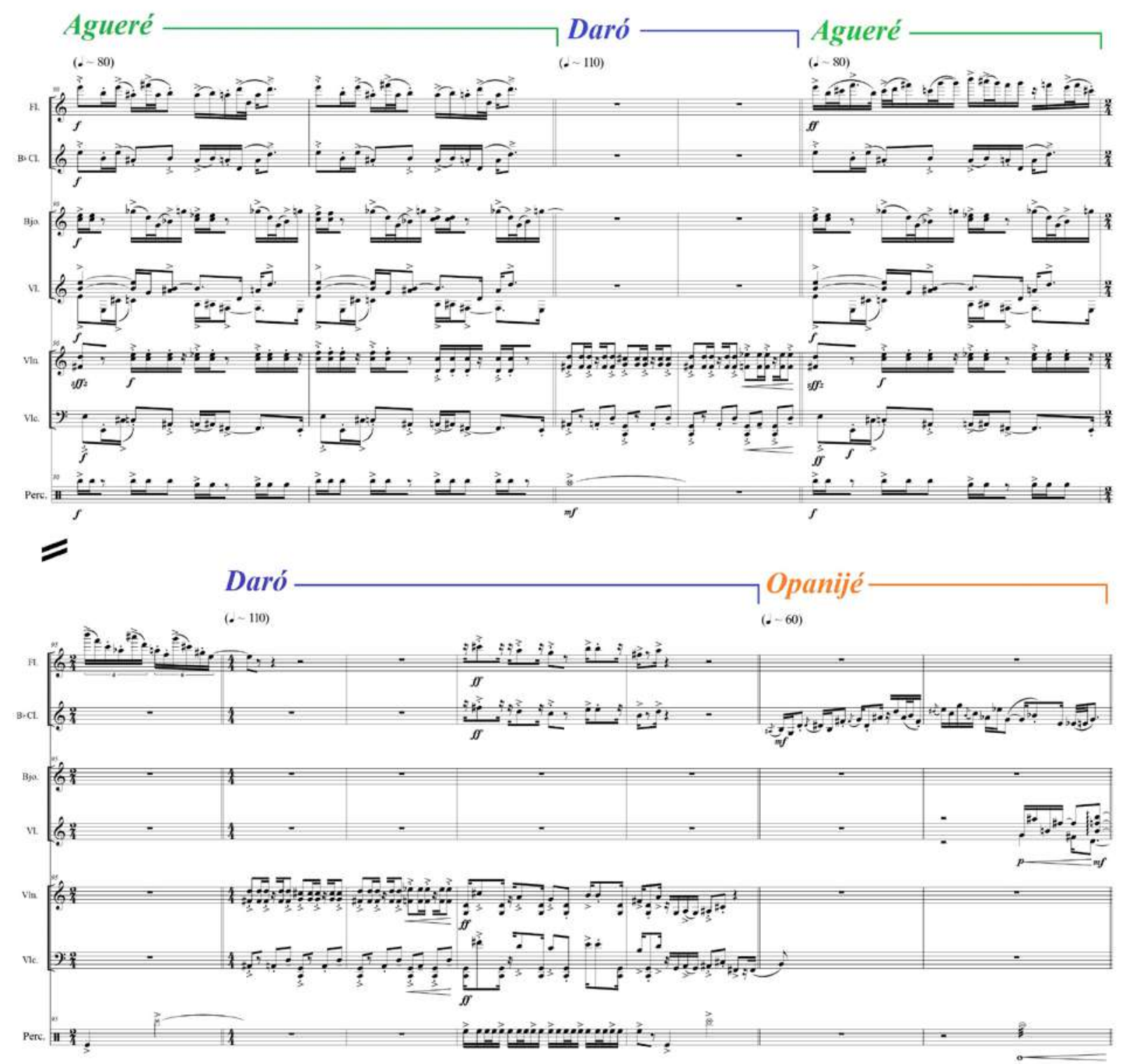

Exemplo 25: Processo modulante de claves em sucessão, em Impulsos

\subsubsection{Lapsos de um Encontro}

Lapsos de um Encontro foi escrita para flautas andinas, charango e violão, em colaboração com Katalina Gutiérrez (flautas andinas e charango) e Vladimir Bonfim (violão), durante uma série de encontros semanais ao longo dos meses de março e abril de 2018.

Devo dizer que, a princípio, trabalhar com Katalina e Vladimir foi um grande desafio composicional - se por um lado tínhamos o violão, instrumento que conheço relativamente bem e que seria tocado por Vladimir, um instrumentista que eu já conhecia e que é especialista em performance de música contemporânea (o meu metier), por outro, tínhamos as flautas andinas e o charango, instrumentos que eu mal conhecia e que seriam tocados por Katalina, estrangeira, recém-apresentada a mim e que fazia parte de um contexto musical completamente diferente (atrelado à música tradicional andina). 
Diante desta problemática, o mais sensato foi começarmos o trabalho por uma conversa, onde falaríamos de música numa concepção geral, apresentaríamos os instrumentos envolvidos (técnicas, sonoridades etc.) e sentiríamos como eles poderiam funcionar conjuntamente. Feito isso, a estratégia inicial foi bolar um excerto musical com certa consistência e apresentar aos instrumentistas para ver o que eles achavam. Depois das impressões e aprovação deles, propus, em conversa, o planejamento da obra.

Em termos gerais, a peça respondeu a um intento narrativo relativo às minhas impressões musicais e pessoais acerca dos instrumentistas. Nesta direção, a composição se encarregou de promover conflitos e acordos sonoros entre a música andina (ponderando minha falta de conhecimento profundo sobre o assunto e visão tendida a uma deturpação) e o imaginário abrangente da música brasileira contemporânea. Obviamente, as minhas intenções não eram a representação dos instrumentistas parceiros no tecido musical, muito menos da música andina ou contemporânea brasileira, mas coletar materiais específicos para tentar fazer com que ambos se sentissem presentes na peça, ainda que parcialmente, e a partir disso construir um discurso compositivo.

Esse jogo de promoção de conflitos e acordos segundo as metáforas musicais das identidades dos instrumentistas (evidentemente a partir da minha leitura) é o motor do perfil global da composição. A obra está dividida em oito seções que se estabelecem através da alternância do protagonismo sonoro de características relativas ao universo musical de um ou de outro instrumentista, como pode ser observado na seção 2, exemplo 26 (c. 15-22), onde gestos idiomáticos do violão e pertencentes ao imaginário da música contemporânea determinam as relações musicais; e na seção 7, exemplo 27 (c. 76-96), onde ritmos tradicionais andinos assumem a superfície musical e condicionam as implicações compositivas.

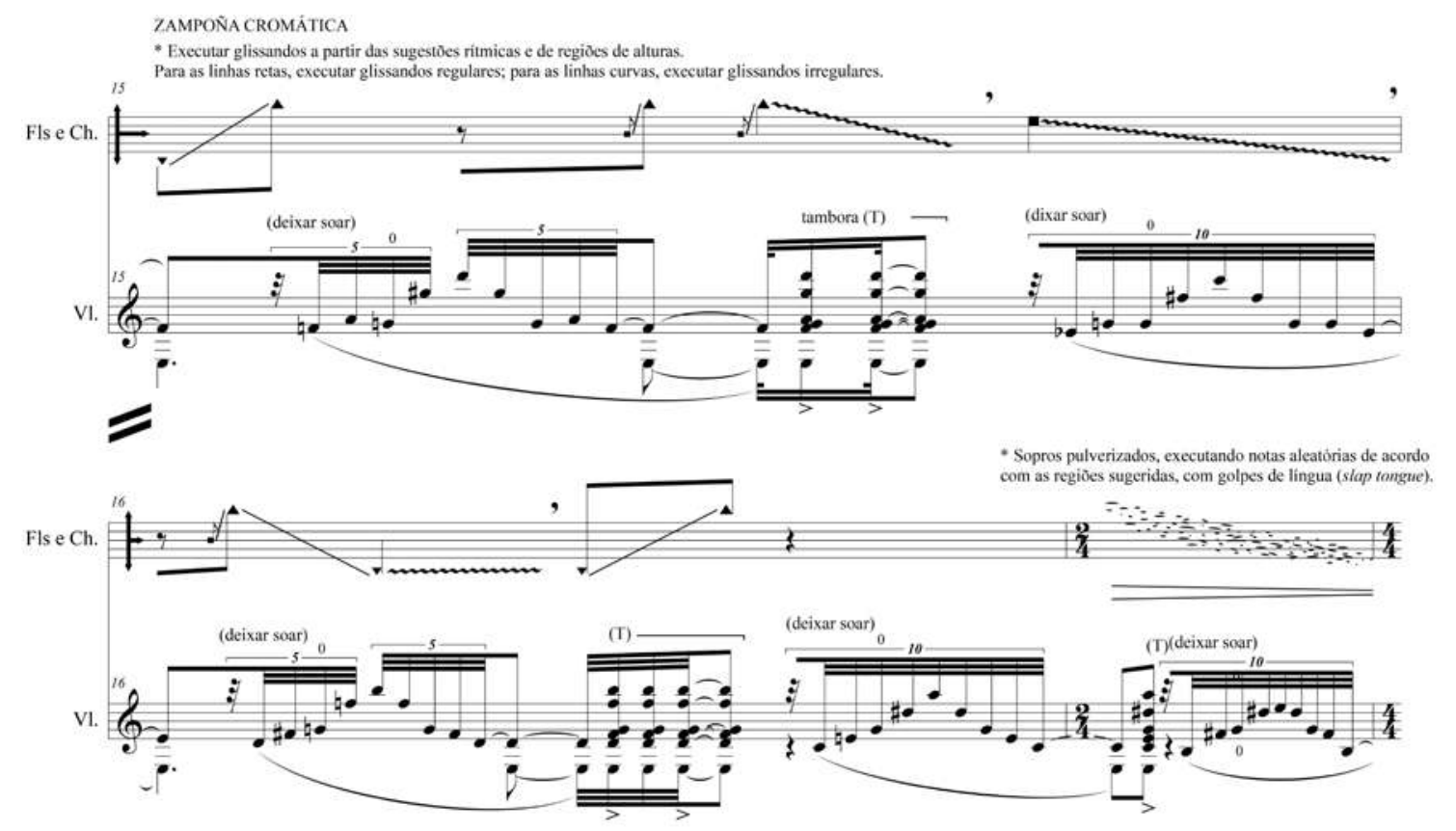

Exemplo 26: Trecho da seção 2, de Lapsos de um Encontro 


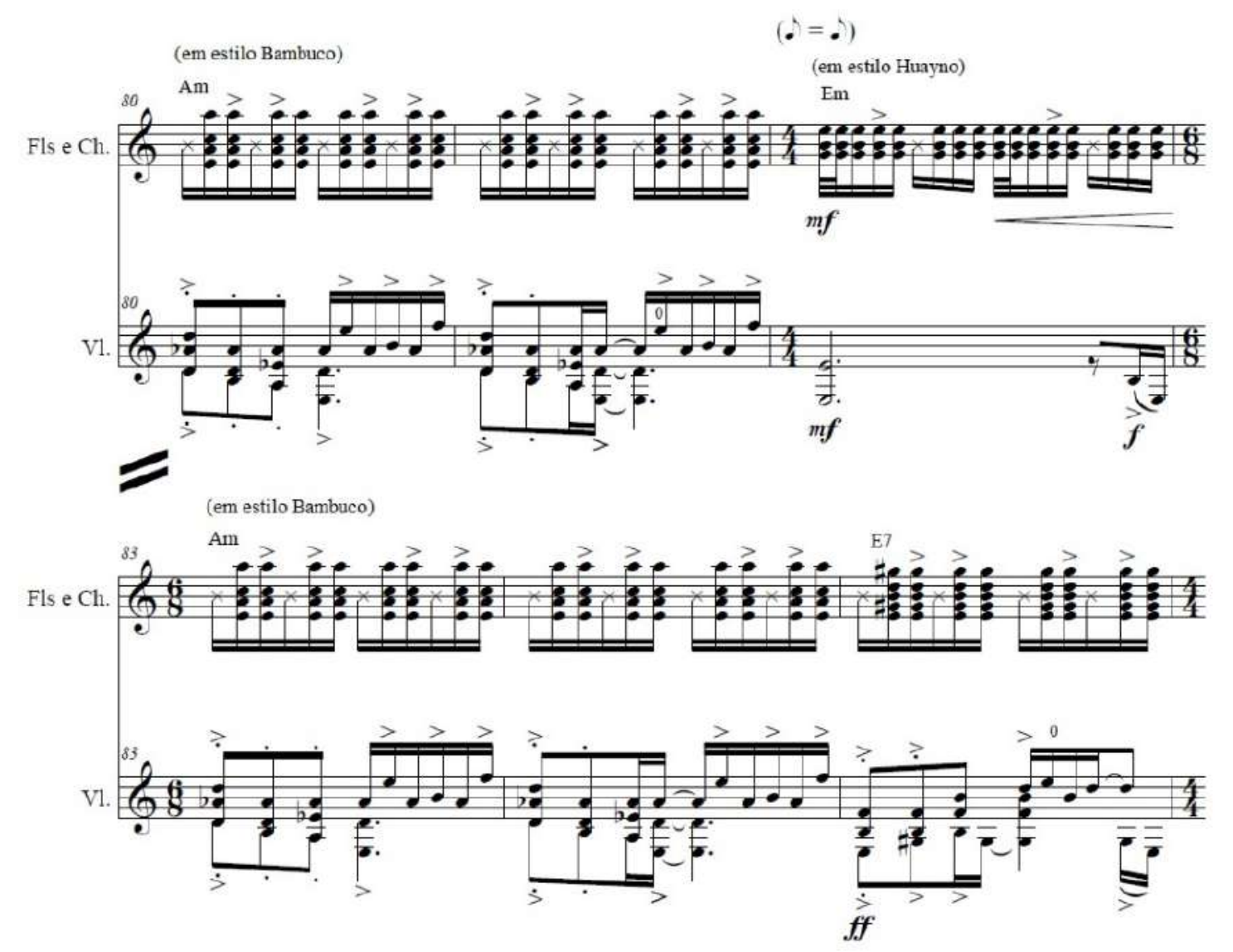

Exemplo 27: Trecho da seção 7, de Lapsos de um Encontro

\subsubsection{Situação analítica I: a ressignificação rítmica como processo de promoção de conflitos rítmicos e métricos}

Durante toda a seção 4 de Lapsos de um Encontro (c. 32-48), há um circuito compositivo de conflitos favorecido pela noção de ressignificação rítmica. Neste, existe uma alternância constante de materiais musicais distintos por suas especificidades, que são expostos no primeiro plano sonoro, ora apresentados pelo charango, ora apresentados pelo violão. Quando um material é apresentado por um desses instrumentos, o outro impõe, em contraponto e a princípio como plano de fundo, um material diversificado, de características agrupacionais e, consequentemente, métricas contrastantes, cuja função é promover uma nova perspectiva rítmica intuitiva do material inicialmente apresentando, implicando uma ressignificação do mesmo.

O exemplo 28 ilustra tal processo. Observemos que é apresentado no charango um material que condensa arpejos regulares agrupados de três em três semicolcheias (c. 37 e 38), quando, num caminho paralelo a este e em contraponto, surge um material no violão (c. 39 e 40), também constituído de uma sucessão de arpejos, embora estruturado de agrupamentos que envolvem um conjunto de cinco semicolcheias - os novos impulsos métricos associados ao material do violão promovem em todo o excerto musical uma nova configuração de acentuações, que proporciona um novo modo de 
escuta para os arpejos executados no charango. Adiante ocorre algo parecido: o referido contraponto de violão se transforma em um material igualmente de agrupamentos assimétricos $(5+7)$, que protagoniza o discurso musical a partir dos compassos 41 e 42 , o qual é submetido a arpejos quaternários executados pelo charango, como acompanhamento a partir do compasso 43, que o ressignifica, no sentido de impor ao contexto sonoro uma nova sensação rítmica e métrica.

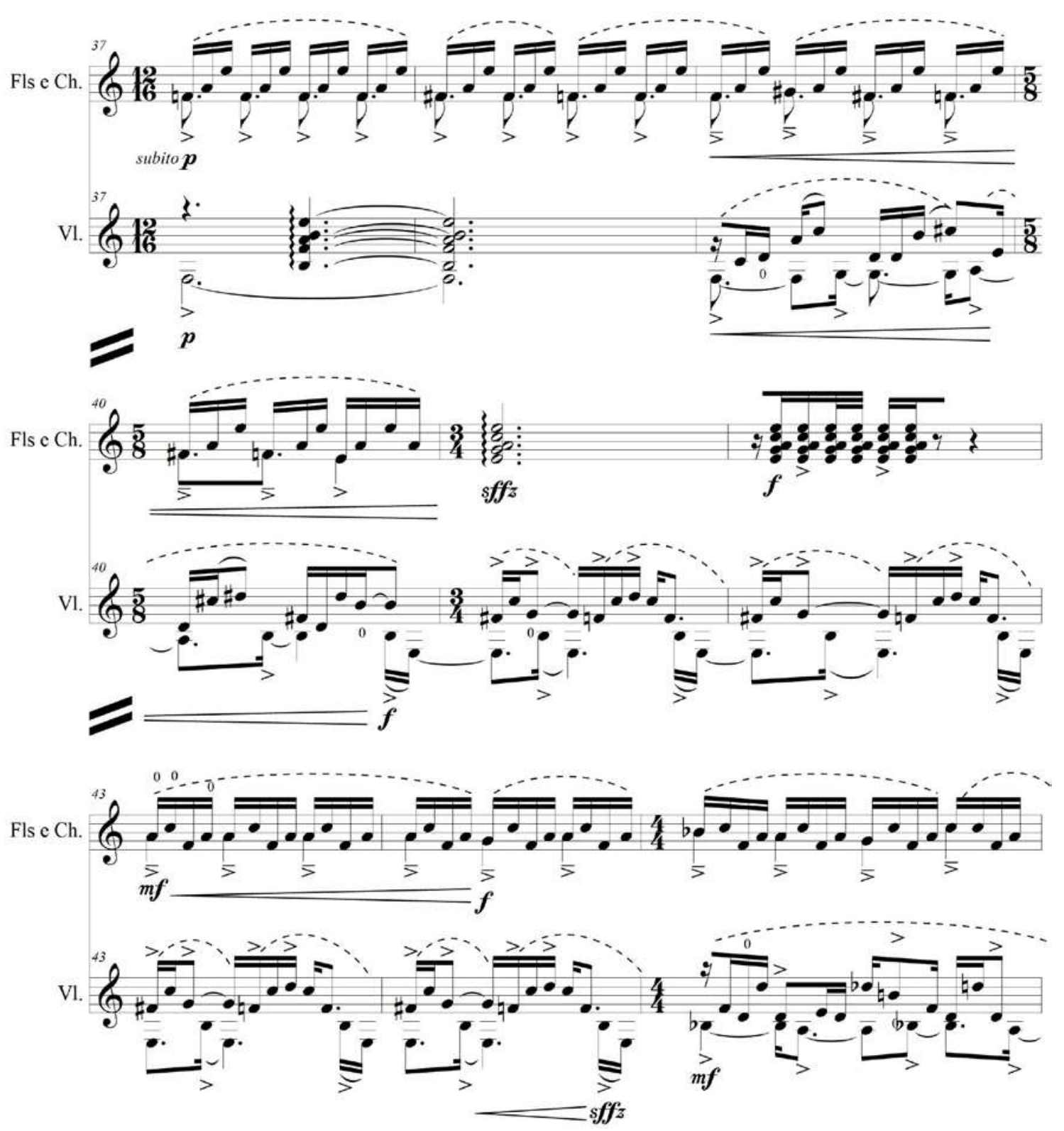

Exemplo 28: A ressignificação rítmica como processo de promoção de conflitos rítmicos e métricos, em Lapsos de um Encontro 


\subsubsection{Situação analítica II: a dissociação rítmica como processo de desenvolvimento rítmico e gestual}

De modo muito similar ao que é relatado no exemplo 21, observam-se seções em Lapsos de um Encontro onde a construção de gestos é moldada a partir do implemento do processo de dissociação rítmica. O exemplo 29 demonstra o encontro de dois materiais musicais distintos - um padrão rítmico formulado através duma variação da clave de candomblé opanijé, que sustenta acordes idiomáticos no charango, e um fragmento melódico ressonante de violão - que juntos formam um composto sonoro (marcado em seta azul, c. 99). A partir de então, o membro do composto correspondente à parte do violão é pouco a pouco desenvolvido ritmicamente numa trajetória de intensificação (marcada em linha vermelha) que dialoga com uma reminiscência do composto primário mantida pela imutabilidade do charango, até que atingem, no compasso 133, um grau considerável de independência, como um ponto de finalização do fluxo gestual.

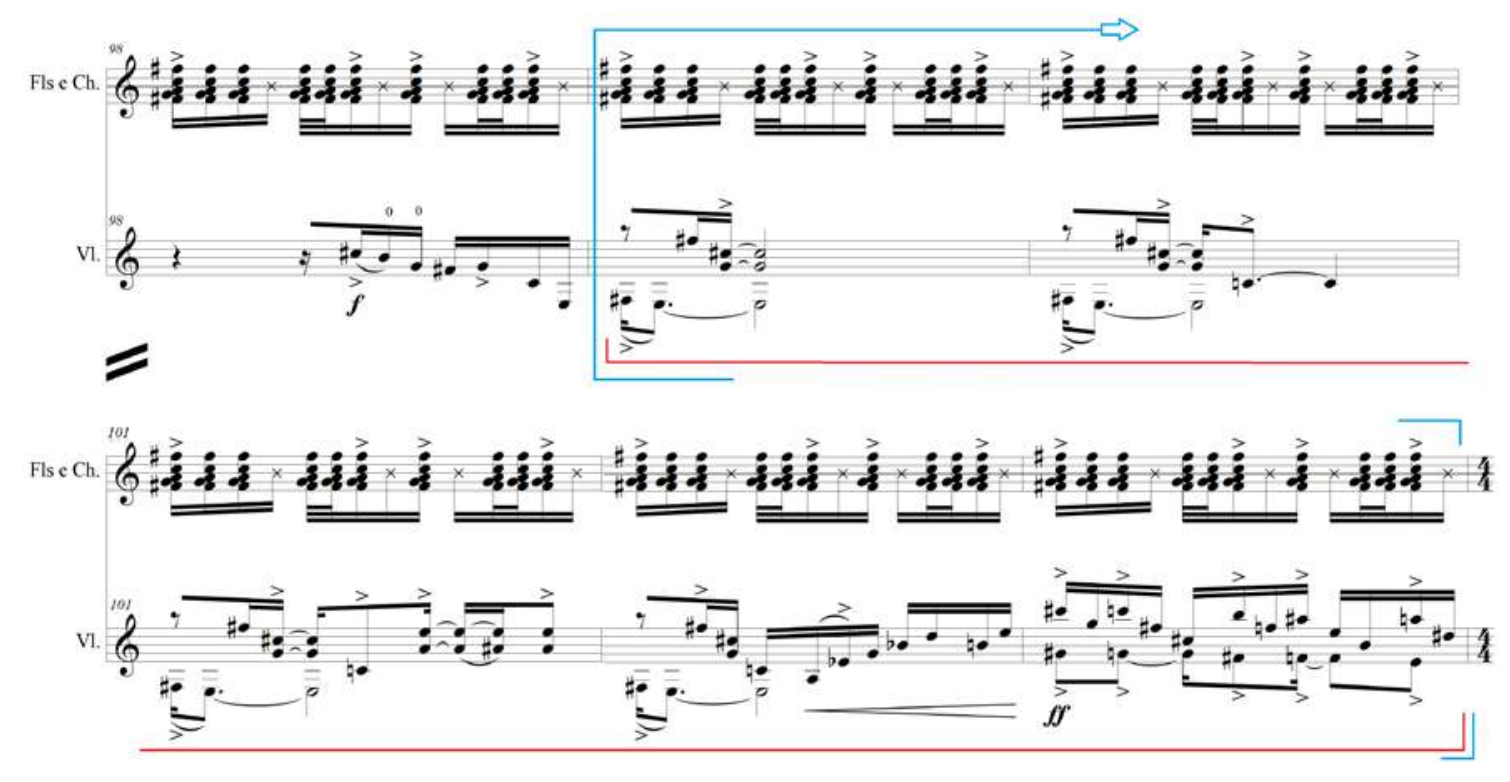

Exemplo 29: A dissociação rítmica como processo de desenvolvimento rítmico e gestual, em Lapsos de um Encontro

\subsubsection{Ecos n. 3 (sobre o primeiro impulso)}

A última das obras a ser comentada no contexto deste artigo responde a um convite do percussionista Jorge Sacramento, para participar de um projeto envolvendo a criação de peças para voz solista e grupo de percussão, que foram registradas no mais novo disco do Grupo de Percussão da UFBA - Ouça Sfot Poc, ${ }^{28}$ gravado entre 2018 e 2019.

Ecos é uma série de peças que venho desenvolvendo para voz (solistas) e grupo de câmara, cuja concepção diz respeito à metáfora da voz como uma encarnação plena do "eu poético" atrelado aos textos escolhidos, e o grupo instrumental como uma espécie 
de manifestação do que é reverberado e ecoado de sua psique. Nesta ocasião, decidi tratar de um tema pouco visitado quando se analisa o imaginário da música de concerto contemporânea: o amor. Mas o amor aqui tratado é o amor lato sensu, associado à ideia grega do "amor agápico", aquele que supostamente aparece como o impulso que orienta a empatia, a generosidade e a tolerância - por isso o subtítulo é sobre o primeiro impulso. Aliás, a noção de tolerância desperta relações musicais importantes para o planejamento estrutural e artístico da obra. Não por acaso, há na peça referências explícitas de aspectos simbólicos de religiões distintas que, no tecido conjuntivo da obra, encontram um lugar de convivência propositiva - os exemplos 30a e 30b ilustram este aspecto: no primeiro, a ideia do mantra mais importante do hinduísmo, o "Om" ou "Aum", cantado pela solista, encontra-se imerso numa conjuntura rítmica ligada à música de candomblé, apoiada numa fusão das claves ijexá e igbin; e no segundo, um ambiente rítmico similar serve de acompanhamento para uma versão poeticamente licenciada da chamada Oração da Paz, mais conhecida como Oração de São Francisco, associada ao cristianismo.

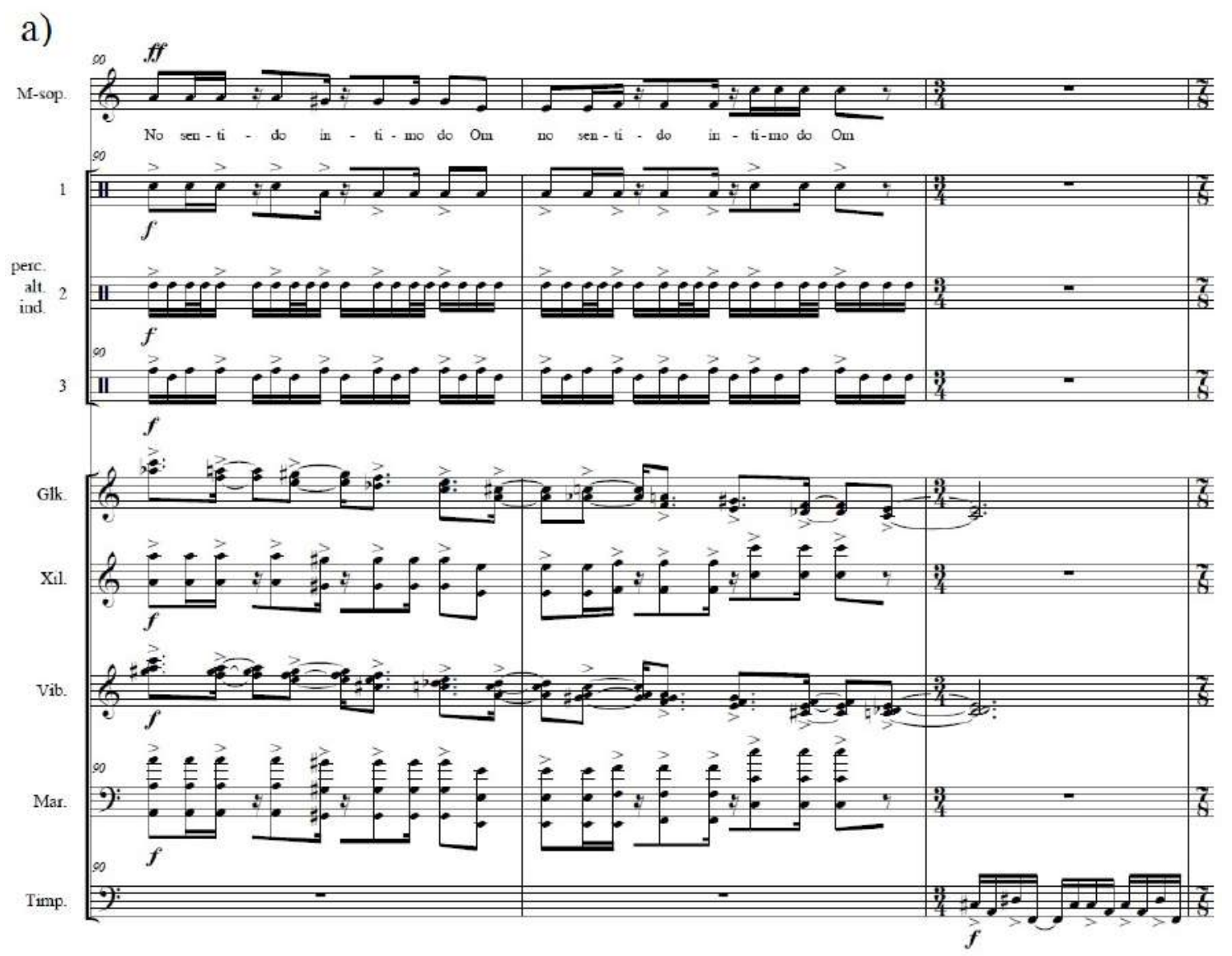




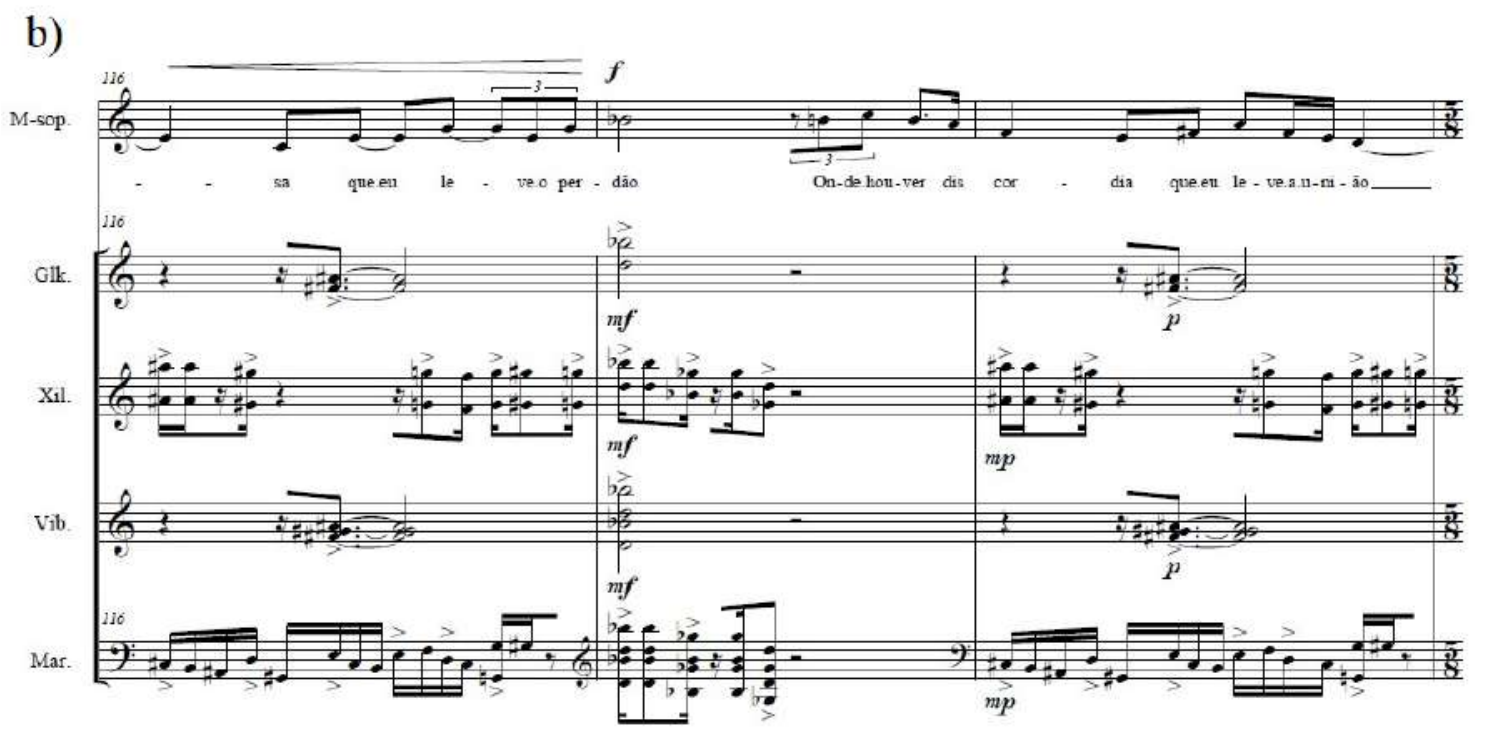

Exemplo 30: Encontro de simbologias religiosas em Ecos n. 3 (sobre o primeiro impulso)

Ademais, resta esclarecer que a formação instrumental completa da composição é voz mezzo-soprano e oito percussionistas (divididos entre instrumentos de altura determinada e indeterminada), e os textos utilizadas são: Ecos do primeiro impulso, de minha autoria, e Oração da Paz (ou Oração de São Francisco), de domínio público.

\section{TEXTOS UTILIZADOS}

\section{Ecos do Primeiro Impulso}

(Vinicius Amaro)

Celebrar o Amor

Ese entregar pra poder ver o mar com algum sabor Othar e ver...

Sentir, chorar e ser o porque do som

Colher o ar, vivenciar o sonhar...

Se deixar levar pelo intimo ritmico de outro othar othar e ver..

Sentir, chorar e ser o porquê do som

Movendo o entorno pelo encanto invulgar

Forindo o encosto do entre-lugar

No sentido intimo do $O_{m}$

Celebrar o Amor
Oração da $P_{a z}$

(dominio público)

Senhor, fazei-me instrumento de vossa paz Onde houver ódio, que eu leve o amor, onde houver ofensa, que eu leve o perdão Onde houver tiscórdia, que eu leve a união onde houver dúvida, que eu leve a fé Onde houver erro, que eu leve a verdade Onde houver desespero, que eu leve a esperança Onde houver tristeza, que eu leve a alegria onde houver trevas, que eu leve a luz 6, Mestre, fazei que eu procure mais Consolar que ser consolato

Compreender que ser compreen dido

Amar que ser amado

Pois é dando que se recebe

É perdoando que se é perdoato

Eé morrendo que se vive para a vida eterna 


\subsubsection{Situação analítica I: a ressignificação rítmica como processo de variação gestual}

Na terceira seção de Ecos n. 3 (sobre o primeiro impulso), há um gesto importante formado a partir de trêmulos de teclados (marimba e vibrafone) e um ostinato sincopado de tímpano (de onde surge um fragmento melódico marcante de glockenspiel), cuja função é a de contenção de uma grande efusão sonora precedente e, progressivamente, de criação de um momento de tensão que promove expectativas para um novo estado de efusão. Este gesto, quando repetido, mostra-se ressignificado em relação à sua versão anterior por alguma variante rítmica que implica uma reconfiguração da sua lógica intuitiva. Desta maneira, a noção de ressignificação rítmica é abordada como processo de variação gestual. Os exemplos 32a e 32b demonstram duas feições do mesmo gesto que, a despeito de suas ligeiras modificações em termos de altura, se diferenciam mesmo pelas divergentes implicações métricas de um toque de congas que, no primeiro caso, impõe uma sensação métrica binária (marcada em linha verde), e, no segundo, uma sensação métrica assimétrica em 5/8 (marcada em linha roxa).

a)
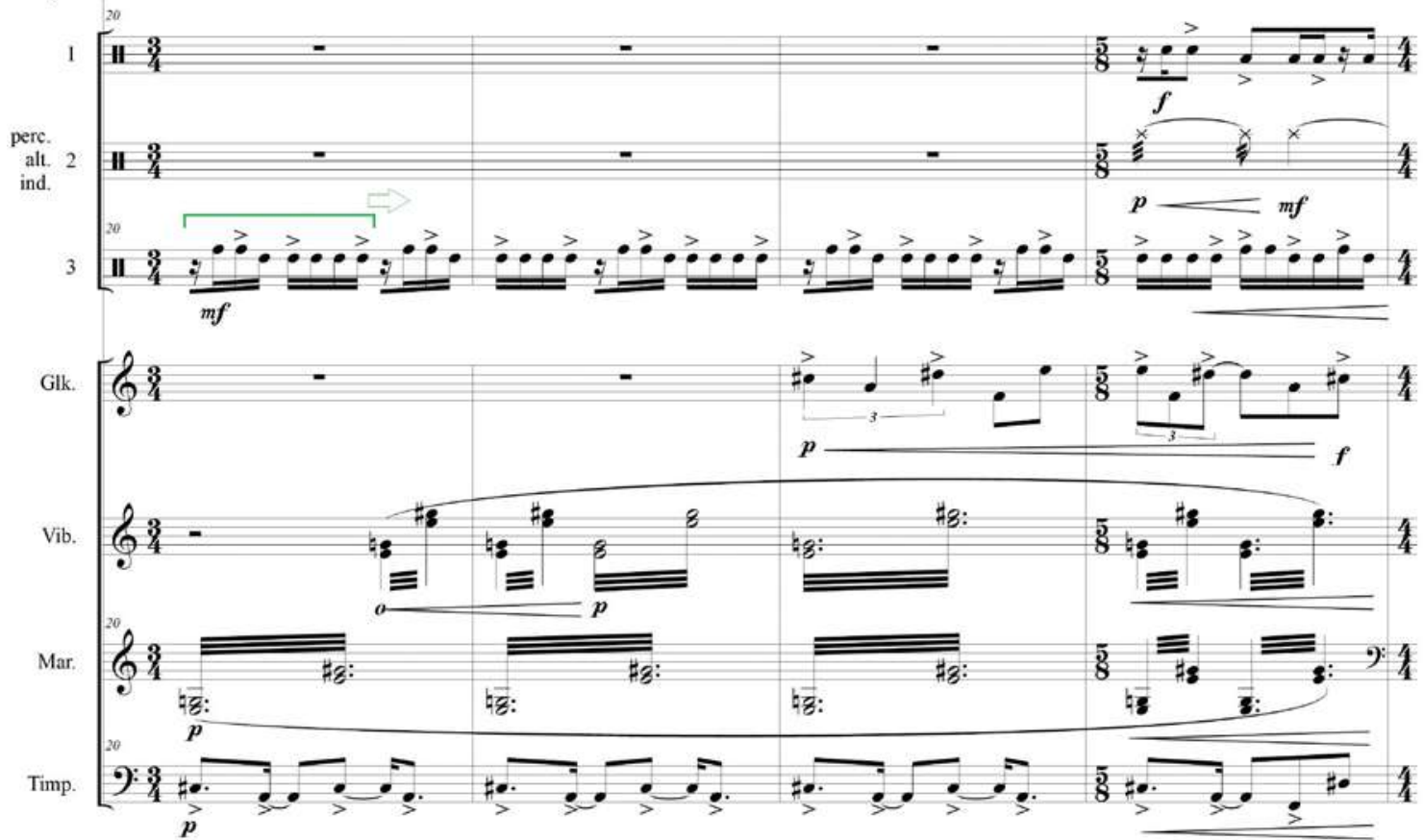
b)
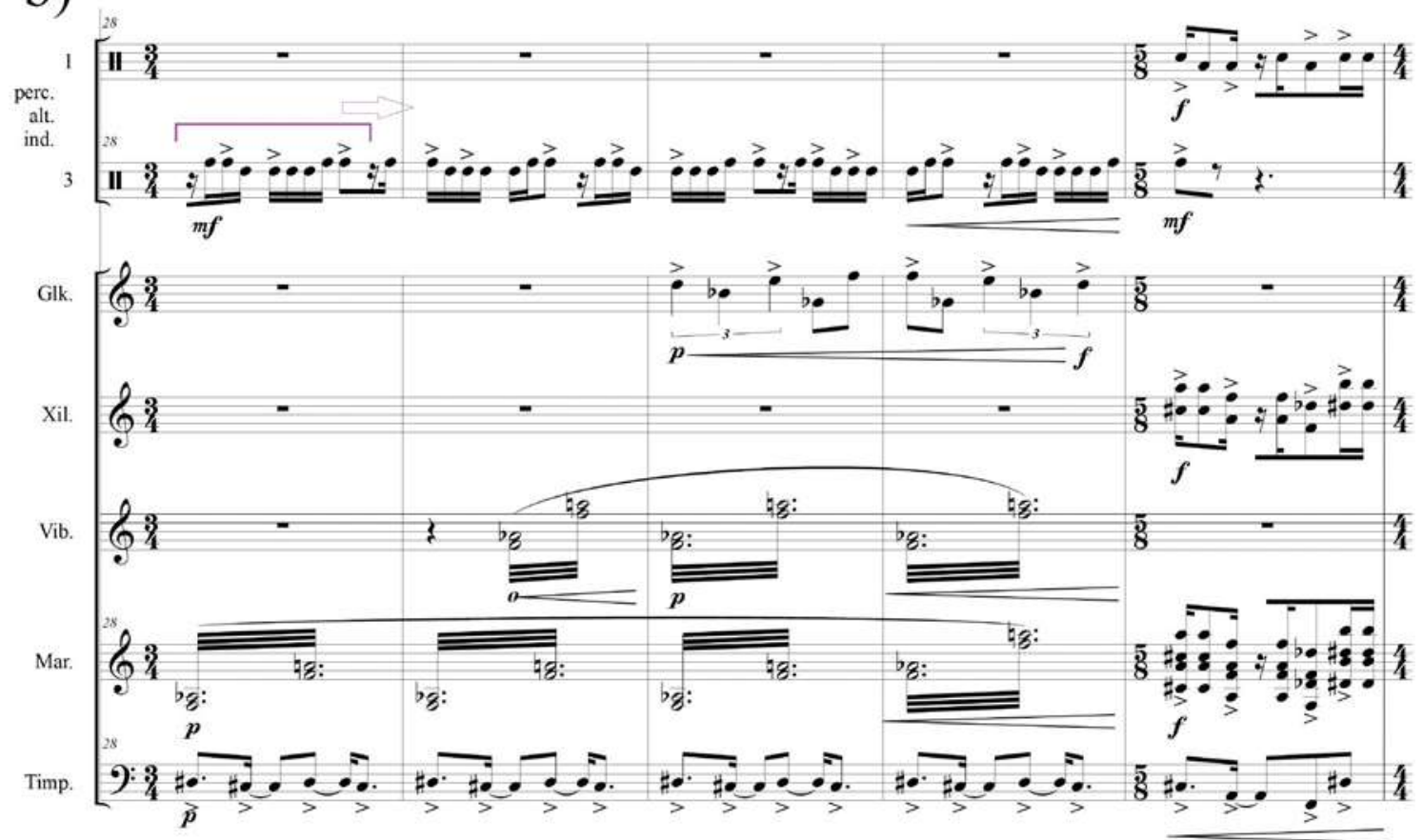

Exemplo 32: A ressignificação rítmica como processo de variação gestual em Ecos $n$. 3 (sobre o primeiro impulso)

\subsubsection{Situação analítica II: a sublimação rítmica como processo de transfiguração de caráter}

O fluxo sonoro de $E \cos n$. 3 é marcado por uma variedade de disposições de contrastes, muitas vezes demasiadamente curtos, que implicam alterações contínuas e aparentemente abruptas do caráter da peça. Grande parte destas alterações é desencadeada por uma ação específica da voz solista, que, tal como o rum no contexto da música de candomblé, promove figurações rítmico-gestuais capazes de transfigurar a lógica musical vigente, e, neste sentido, a noção de sublimação rítmica é assumida como um processo de transfiguração do caráter musical. Os exemplos 33a e 33b demonstram este princípio: em ambos há um gesto melódico de impulso anacrústico realizado pela voz, sendo que, no primeiro caso, de modo ascendente, reaviva uma construção gestual de médio porte presente no início da obra (discutida nos exemplos 32a e 32b), promovendo um grande contraste em relação ao que o precede; e, no segundo, de modo descendente, promovendo a anunciação de um novo contraste que, no caso, diz respeito à instituição de uma nova seção (a última parte da obra, antes da recapitulação de seu início). 


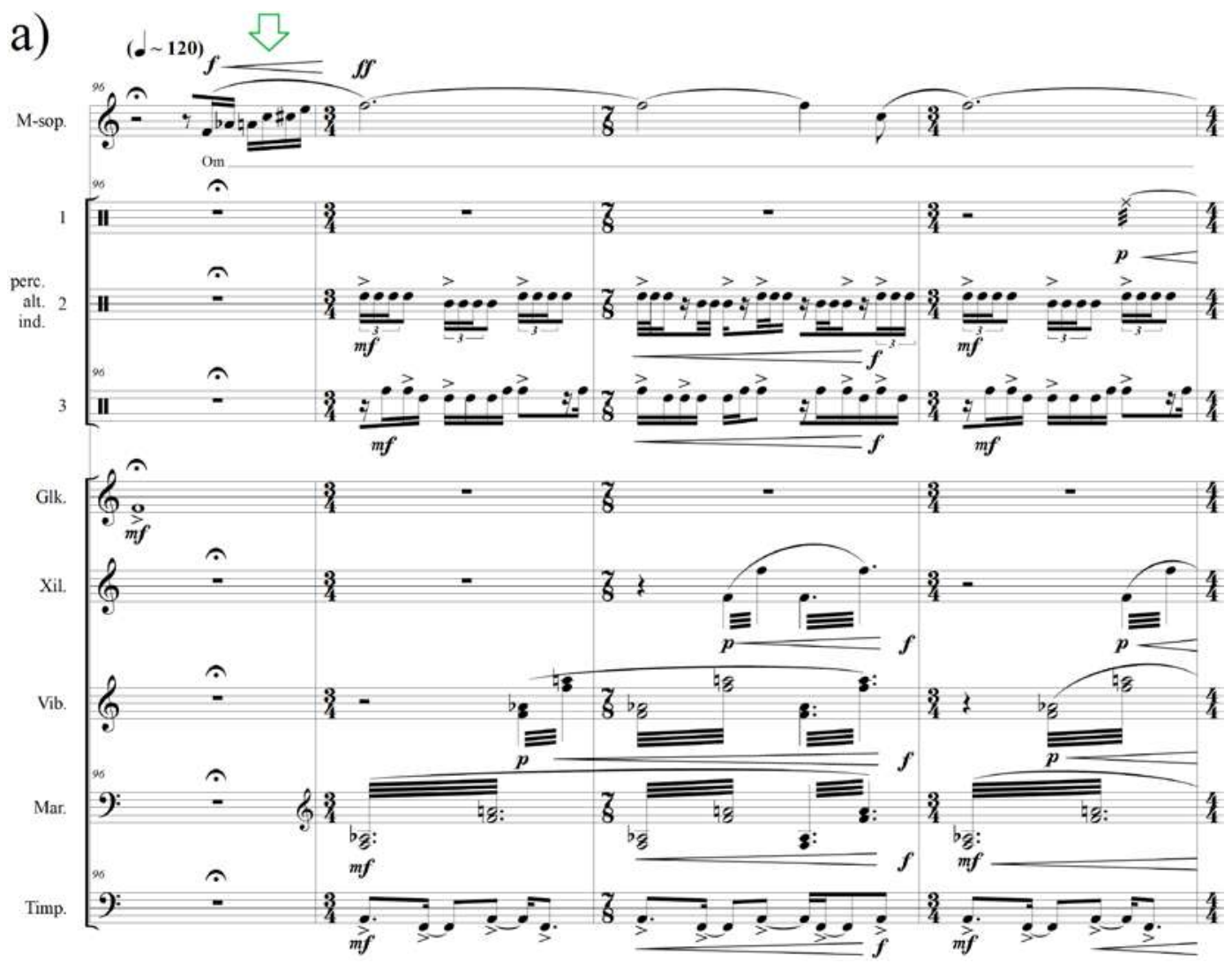

b)
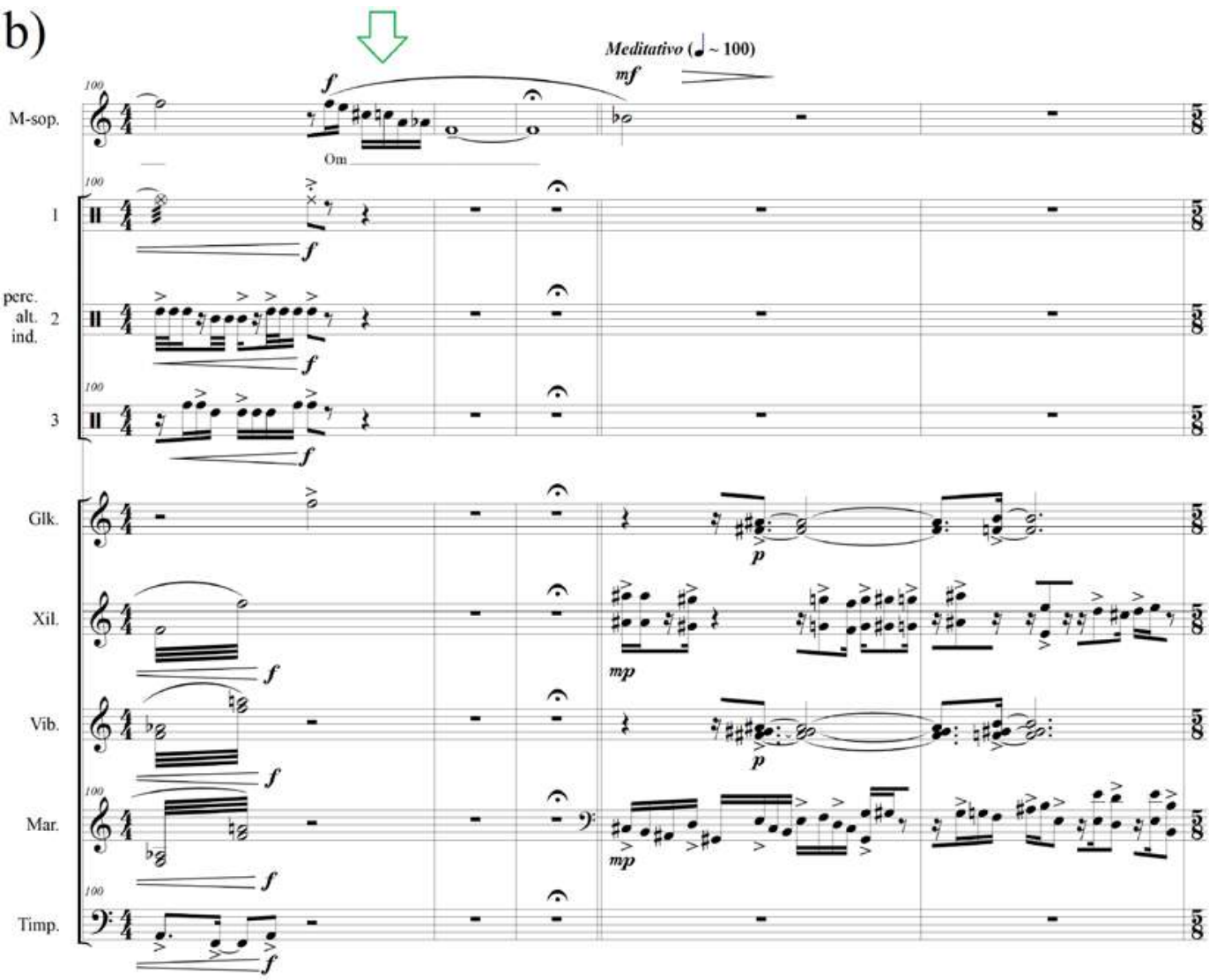

Exemplo 33: A sublimação rítmica como processo de transfiguração de caráter, em Ecos n. 3 (sobre o primeiro impulso) 


\subsubsection{Situação analítica III: a dissociação rítmica como processo de intensificação gestual}

No clímax de Ecos n. 3 (c. 130-141), um trecho importante da Oração da Paz é entoado numa conjuntura rítmica que faz alusão à sonoridade mais orgânica do quarteto instrumental de candomblé, que cresce pouco a pouco mediante a adição dos teclados, até que chega ao compasso 138 num alto grau de energia, ainda inédito na peça (potencializado pelo simbolismo da seção). Um ingrediente fundamental para esta construção dramática é uma extensa frase de tímpano (marcada em linha roxa), que, a princípio incipiente enquanto membro do composto rítmico que simula o quarteto instrumental de candomblé (marcado em colchetes amarelos) e que, desde antes da entrada dos teclados, passa por um processo de desmembramento, ficando cada vez mais particularizada, até que se mostra completamente dissociada (c. 137 e 138), impondo suas características de acentuações rítmicas próprias. Esta traquitana compositiva, ilustrada no exemplo 34, demonstra uma estratégia de utilização da noção de dissociação rítmica como processo de intensificação gestual - os números em roxo marcam os passos progressivos da dissociação. 

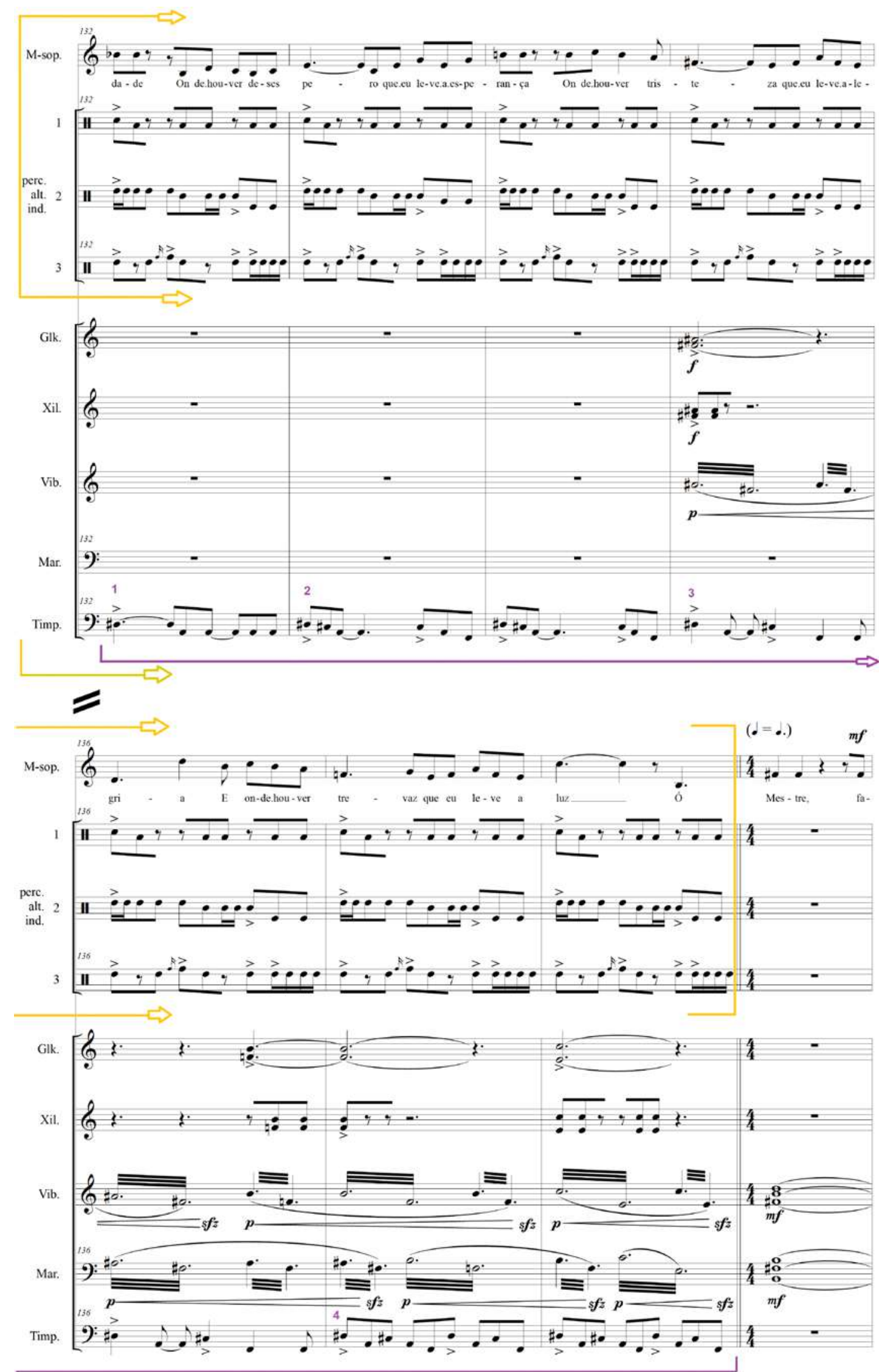

Exemplo 33: A dissociação rítmica como processo de intensificação gestual, em $E \cos n .3$ (sobre o primeiro impulso) 


\section{Comentários de síntese}

No presente artigo, cinco obras musicais foram abordadas no sentido objetivo de uma demonstração, com ênfase descritiva e analítica, de suas implicações relativas a uma pesquisa de interface entre composição e etnomusicologia acerca dum suposto compor ligado à música de candomblé, assumido na observação de seus processos rítmicos. Na realidade, cultivo a impressão de que tais peças não apenas aferem ou respondem ao impulso essencial que se apresenta como motivo central da pesquisa, como também podem ser encaradas como uma manifestação alternativa da própria investigação, afinal, composição não é só um comentário, uma opinião ou uma exibição, e sim "uma experiência multidimensional, que pode conduzir o ouvinte através de um determinado caminho, que propõe uma paisagem para exploração, de tal maneira que um arco, uma trajetória propositiva com engajamento e resposta terá sido percorrida ao final"29 (REYNOLDS, 2002, p.3).

Sendo assim, e a despeito da resistência histórica à ideia de que a pesquisa em artes, e mais especificamente em composição, pudesse dispensar a tradução de suas realizações para o plano discursivo - o que implicou a fundamentação do modelo tradicional de pós-graduação em artes no Brasil, que nos últimos anos vem sendo oxigenado pela concepção de pesquisa artística -, atrevo-me a dizer que o conjunto dessas obras é, em si, uma feição da própria pesquisa, visto que nele está, em representação sônica, as razões que movem o traçado discursivo que tecemos até aqui. Notemos que:

1. O que inspira a concepção de cada uma das obras é a esperança de que música, ainda que num contexto de concerto, pode ser muito mais que informação sonora e experiência cognitiva. O compor, assim, pode carregar um discurso e apresentar um posicionamento político que, inclusive, atenda às demandas sociais. A descolonização do saber, que ganha força em movimentos contra hegemônicos, é uma demanda social atual que, no domínio musical, desperta interesses importantes neste trabalho. É daí que surge um pensamento articulado da união de forças entre os campos da composição e da etnomusicologia, que se assume como o espírito composicional de cada uma das obras. Quer dizer: em nenhumas das aventuras compositivas abordadas aqui a voz que fala como protagonista é a voz da dita música erudita, nem pura e simplesmente a voz de um compositor imune ao seu entorno. Ao contrário, a voz que fala como protagonista de todas as peças é a voz do diálogo entre epistemologias musicais, ou seja, uma voz que escuta vozes distintas que dizem coisas diversificadas acerca dos modos de proceder com expressão musical. A princípio, esta é a proposta de trabalho cultural levantada por mim com ponto central das composições;

2. Por aqui, há também um interesse muito específico de não apenas compreender, mas, em igual medida, trazer à tona e compartilhar um possivel compor relativo à epistemologia musical do candomblé, e mais: aprender com ele. É por meio deste intuito que

\footnotetext{
29 Original: "A true composition is not only a remark or stance or display, but a dimensional experience that either leads the listener along a path or proposes a landscape for exploration in such a way that na arc, a trajectory of proposal, engagement, and response has been traversed by its end" (REYNOLDS, 2002, p.3).
} 
o processo criativo das obras se emancipa, no sentido de uma perspectiva decolonial dos paradigmas epistêmicos da música de concerto contemporânea. Não por acaso, os processos compositivos que as fundamentam, de maneira criativa e ressignificada, são aqueles observados na música de candomblé. A propósito, é importante destacar que, na proposta de trabalho cultural realizado pelas obras, há também o compromisso de expor características compositivas da epistemologia musical em questão de modo explicativo - claro, com a ressalva de que cada obra ocupa o seu lugar no mundo e se apresenta na cabeça de cada ouvinte de maneira completamente imprevisível.

Seja como for, com as reverberações deste trabalho se espera contribuir com o que é discutido atualmente em composição, sobretudo no que diz respeito à música contemporânea, em suas dimensões poéticas, estéticas e filosóficas, no horizonte frutífero da interdisciplinaridade.

\section{REFERÊNCIAS}

AGAWU, Kofi. Representing african music: postcolonial notes, queries, positions. New York: Routledge, 2003.

AGAWU, Kofi. Structural analysis or cultural analysis? Competing perspectives on the "standard pattern" of west african rhythm. Journal of the American Musicological Society, n. 59, p. 1-46, 2006.

AGAWU, Kofi. The african imagination in music. New York: Oxford University Press, 2016.

ALMÉN, Byron. A theory of musical narrative. Bloomington: Indiana University Press, 2008.

AMARO, Vinicius; LIMA, Paulo C. O compor do Candomblé: uma abordagem analítica em direção a um diálogo com a música de concerto contemporânea. In: Paralaxe 2: perspectivas de interpretação, teoria e composição musical. Salvador: Ed. UFBA, 2016. p. 185-212.

BERRY, Wallace. Structural functions in music. New York: Dover, 1976.

BOHLMAN, Philip V. Music and culture: historiographies of disjuncture. In: CLAYTON, Martin; HERBERT, Trevor; MIDDLETON, Richard (ed.). The cultural study of music: a critical introduction. New York: Routledge, 2003. p. 45-56.

BRANDA LACERDA, M. Música instrumental no Benin: repertório Fon e música Bàtá. São Paulo: Ed. Universidade de São Paulo, 2014. 
BRÜN, Herbert. My words and where i want them. London; Champaign: Princelet Editions, 1990.

BRÜN, Herbert. When music resists meaning: the major writings of Herbert Brün. Org. Arun Chandra. Middletown: Wesleyan University Press, 2004.

Cage. New Haven: Yale University Press, 2002.

CANCLINI, Néstor G. Culturas híbridas: estratégia para entrar e sair da modernidade. São Paulo: Ed. Universidade de São Paulo, 2008.

CANO, R. L.; OPAZO, U. S. C. Investigación artística en música: problemas, métoาdos, experiencias y modelos. Barcelona: Fonca-Esmuc, 2014.

CARDOSO, Ângelo N. A linguagem dos tambores. 2006. 402 f. Tese (Doutorado em Etnomusicologia) - Programa de Pós-Graduação em Música, Escola de Música, Universidade Federal da Bahia, Salvador, 2006.

CARNEIRO, Edison. Candomblés da Bahia. 9. ed. São Paulo: WMF Martins Fontes, 2008.

CASTORIADIS, Cornelius. A instituição imaginária da sociedade. Rio de Janeiro: Paz e Terra, 1982.

CHUA, Daniel. Absolute music and the construction of meaning. New York: Cambridge University Press, 1999.

COOPER, Grosvenor; MEYER, Leonard. The rhythmic structure of music. Chicago: The University of Chicago Press, 1960.

GUGGISBERG, Sonia. O procedimento de tradução na Cultura, na arte e sua condição antropofágica. Crise, tradução e processos sociais, Algazarra, São Paulo, n. 4, p. 133145, dez. 2016.

HASTY, Christopher F. Meter as rhythm. New York: Oxford University Press,1997.

KLEIN, Michael; REYLAND, Nicholas. Music and Narrative since 1900. Bloomington: Indiana University Press, 2013.

KRAMER, Jonathan D. The time of music. New York: Schirmer, 1988.

KUBIK, Gerhard. Theory of african music. Chicago: University of Chicago Press, 2010 a. V. 1. 
KUBIK, Gerhard. Theory of african music. Chicago: University of Chicago Press, $2010 \mathrm{~b}$. V. 2.

LACERDA, Marcos Branda. Música instrumental no Benin: repertório Fon e música Bàtá. São Paulo: Ed. Universidade de São Paulo, 2014.

LAKOFF, George; JOHNSON, Mark. Philosophy in the flesh: the embodied mind and its challenge to western thought. New York: Basic Books, 1999.

LASKE, Otto E. Toward an epistemology of composition. Journal of New Music Research, v. 20, n. 3, p. 235-269, 1991.

LERDAHL, Fred; JACKENDOFF, Ray. A generative theory of music. Cambridge: MIT Press, 1987.

LIMA, Paulo C. Ernst Widmer e o ensino de composição musical na Bahia. Salvador: Faz Cultura, Copene, 1999.

LIMA, Paulo C. Baião de dois: composição e etnomusicologia no forró da pósmodernidade (em seis passos). In: LIMA, Paulo C. Invenção \& memória: navegação de palavras em crônicas e ensaios sobre música e adjacências. Salvador: Ed. Universidade Federal da Bahia, 2005a.

LIMA, Paulo C. Invenção \& memória: navegação de palavras em crônicas e ensaios sobre música e adjacências. Salvador: Ed. Universidade Federal da Bahia, 2005b.

LIMA, Paulo C. Composicionalidade e o Trabalho cultural do Movimento de Composição da Bahia. In: A experiência musical: perspectivas teóricas. Salvador: EDUFBA, 2019. Série Congressos da TEMA, n. 3, p. 36-59.

LÓPEZ-CANO, R.; SAN CRISTÓBAL, U. Investigación artística en música: problemas, métodos, experiencias y modelos. Barcelona: Fonca-Esmuc, 2014.

LÓPEZ-CANO, R. Pesquisa artística, conhecimento musical e a crise da contemporaneidade. Art Research Journal, v. 2, n. 1, p. 69-94, 2015.

LÜHNING, Ângela. Música: coração do candomblé. Revista USP, n. 7, p. 115-124, 1990.

LÜHNING, Ângela.; TUGNY, Rosângela P. Etnomusicologia no Brasil. Salvador: Ed. UFBA, 2016.

MARÍN, José Perú. Interculturalidade e descolonização do saber: relações entre saber 
local e saber universal, no contexto da globalização. Visão Global, Joaçaba, v. 12, n. 2, p. 127-154, jul./dez. 2009.

MENDES, Gilberto. Vento Noroeste. Piano Solo, 1982. Partitura. Serviço de Difusão de Partituras, Escola de Comunicação e Artes da Universidade de São Paulo.

MESSIAEN, Olivier. Cantéyodjayâ. Piano Solo. 1949. Partitura. Disponível em: https:// pt.scribd.com/document/369725018/Messiaen-Canteyodjaya-pdf. Acesso em: 3 jul. 2020.

NETTL. Bruno. The study of ethnomusicology: thirty-one issues and concepts. Urbana, Chicago: University of Illinois Press, 2005.

OLIVEIRA FILHO, Pedro Amorim. Compor no mundo: um modelo de compor música sobre bases fenomenológicas. 2014. 390 f. Tese (Doutorado em Música) Universidade Federal da Bahia, Salvador, 2014.

OLIVEIRA, Jamary. A respeito de compor: questões e desafios. ART: Revista da Escola de Música da UFBA, Salvador, n. 19, p. 59-69, ago. 1992.

PÊCHEUX, Michel. Análise Automática do Discurso (AAD-1969). In: GADET, Françoise; HAK, Tony (org.). Por uma análise automática do discurso: uma introdução à obra de Michel Pêcheux. Trad. De Eni P. Orlandi. Campinas: Unicamp, 2010. p. 59-158.

PINTO, Tiago de Oliveira. Som e música: questões de uma antropologia sonora. Revista de Antropologia, São Paulo, v. 44, n. 1, p. 221-286, 2001.

QUIJANO, A. A colonialidade do saber. In: LANDER, Edgardo (org.). A colonialidade do saber eurocentrismo e ciências sociais. Perspectivas latino-americanas. São Paulo: Clacso Livros, 2005.

QUIJANO, A. Don Quijote y los molinos de viento. In: SORIA, José Ignacio López (ed.). Andinos y mediterrâneos: claves para pensar iberoamérica. Lima: Fondo Editorial del Congreso de la República, 2007.

REYNOLDS, Roger. Form and method: composing music. New York: Routledge, 2002.

SANTOS, Boaventura de Souza; MENESES, M. P. Epistemologias do Sul. Coimbra: Almedina, 2009.

SEEGER, Anthony. Etnografia da música. Cadernos de campo, São Paulo, n. 17, p. 237$260,2008$. 
SHAW-MILLER, Simon. Visible deeds of music: art and music from Wagner to Cage. New Haven: Yale University Press, 2002.

WIDMER, Ernst. Crítica e Criatividade em 6 movimentos. Comunicação apresentada à XXXIII Reunião Anual da SBPC, no Simpósio sobre Universidade e Realidade: o papel do senso crítico. Salvador, 5p. (Inédito). 1981. 